\title{
Shallow marine syn-rift sedimentation: Middle Jurassic Pelion Formation, Jameson Land, East Greenland
}

\author{
Michael Engkilde and Finn Surlyk
}

The Middle Jurassic Pelion Formation - Fossilbjerget Formation couplet of Jameson Land, East Greenland, is a well-exposed example of the Middle Jurassic inshore-offshore successions characteristic of the rifted seaways in the Northwest European - North Atlantic region. Early Jurassic deposition took place under relatively quiet tectonic conditions following Late Permian - earliest Triassic and Early Triassic rift phases and the Lower Jurassic stratal package shows an overall layer-cake geometry. A long-term extensional phase was initiated in Middle Jurassic (Late Bajocian) time, culminated in the Late Jurassic (Kimmeridgian-Volgian), and petered out in the earliest Cretaceous (Valanginian). The Upper Bajocian - Middle Callovian early-rift succession comprises shallow marine sandstones of the Pelion Formation and correlative offshore siltstones of the Fossilbjerget Formation. Deposition was initiated by southwards progradation of shallow marine sands of the Pelion Formation in the Late Bajocian followed by major backstepping in Bathonian-Callovian times and drowning of the sandy depositional system in the Middle-Late Callovian. Six facies associations are recognised in the Pelion-Fossilbjerget couplet, representing estuarine, shoreface, offshore transition zone and offshore environments. The north-southtrending axis of the Jameson Land Basin had a low inclination, and deposition was sensitive to even small changes in relative sea level which caused the shorelines to advance or retreat over tens to several hundreds of kilometres. Eight composite sequences, termed P1-P8, are recognised and are subdivided into a total of 28 depositional sequences. The duration of the two orders of sequences was about 1-2 Ma and 360,000 years, respectively. The Upper Bajocian P1-2 sequences include the most basinally positioned shallow marine sandstones, deposited during major sealevel lowstands. The lowstands were terminated by significant marine flooding events, during which sandstone deposition was restricted to northern, more proximal parts of the basin. The Upper Bajocian - Middle Bathonian P3-4 sequences show an overall progradational stacking pattern. The sequence boundary at the top of $\mathrm{P} 4$ marks a significant shift in stacking pattern, and the Upper Bathonian - Middle Callovian P5-8 sequences show large-scale backstepping, terminating in a widespread condensed succession at the distal, southern end of the basin. The largescale backstepping was governed by combined tectonically-induced subsidence, reflecting increased rates of extension, and eustatic sea-level rise. The depositional trends of the Pelion Formation - Fossilbjerget Formation couplet provide a well-exposed analogue to contemporaneous subsurface deposits which form major hydrocarbon reservoirs on the west Norway shelf, and in the Northern North Sea.

Keywords: East Greenland, Jameson Land, Upper Bajocian - Middle Callovian, Pelion Formation, Fossilbjerget Formation, sedimentology, sequence stratigraphy, shallow marine - offshore environments, regressive-transgressive clastic wedge

\footnotetext{
M.E.* \& F.S., Geological Institute, University of Copenhagen, Geocenter Copenhagen, Øster Voldgade 10, DK-1350 Copenhagen K, Denmark. E-mail: finns@geo.geol.ku.dk

*Present address: Denerco Oil A/S, Kongevejen 100C, Postbox 110, DK-2840 Holte, Denmark.

E-mail: mke@denerco.dk
} 
The Middle Jurassic of East Greenland was characterised by the onset of rifting in the Late Bajocian, major reorganisation of drainage systems, and a high influx of sand. A gradual west- and northwards onlap onto pro-

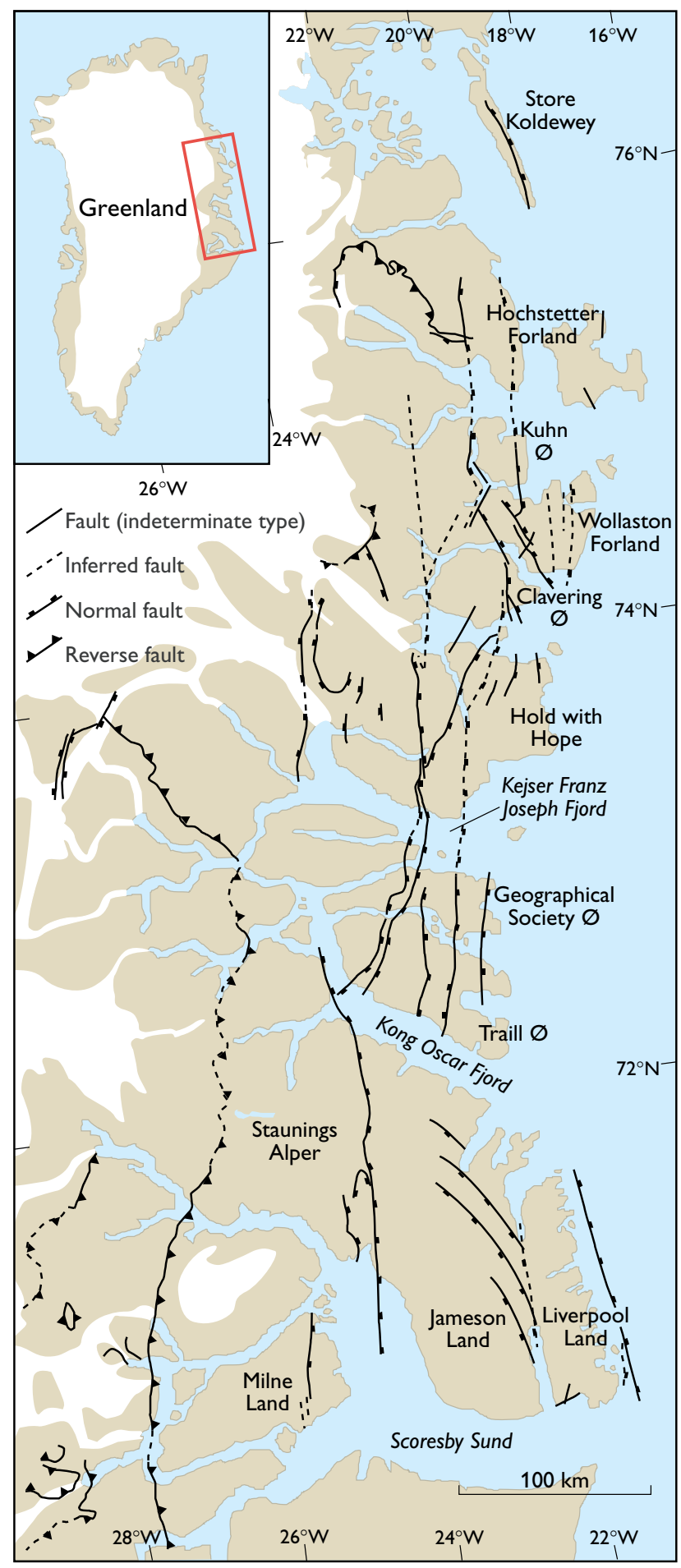

Fig. 1. Map showing fault zones active during the Mesozoic in East Greenland. Place names used in the text are shown. Modified from Surlyk (1991). gressively older strata took place during Late Bajocian - Callovian times. Upper Bajocian sand- and siltstones of the basal Pelion Formation rest on Lower Bajocian mudstones of the Sortehat Formation in Jameson Land at the southern end of the East Greenland basin (Fig. 1); lithostratigraphic usage in this paper follows the provisional revised scheme in Surlyk (2003, this volume, fig. 5). The age of the Sortehat Formation is determined by dinoflagellates (Underhill \& Partington 1994; Koppelhus \& Hansen 2003, this volume), and by Sr-isotope stratigraphy (M. Engkilde, unpublished data). Further north, on Traill $\varnothing$, presumed Middle Jurassic fluvial pebbly sandstones of the Bristol Elv Formation (Therkelsen \& Surlyk in press) or Upper Bajocian shallow marine sandstones of the Pelion Formation rest on Upper Triassic redbeds of the Flemming Fjord Formation and there is no evidence for the presence of Lower Jurassic strata. At Hold with Hope, the Pelion Formation overlies the Lower Triassic Wordie Creek Formation (Stemmerik et al. 1997; Vosgerau et al. in press a), and on Wollaston Forland it rests on a thin Upper Permian carbonate-evaporite unit or directly on Caledonian crystalline basement. Further north again, on Kuhn $\varnothing$, Upper Bathonian or Callovian strata of the fluvial Bastians Dal Formation (Alsgaard et al. 2003, this volume) or the marine Pelion Formation rest directly on the basement. In Hochstetter Forland, Callovian coal-bearing paralic deposits of the Upper Bathonian(?) - Middle Callovian Muslingebjerg Formation or marine Callovian-Oxfordian sandstones of the Payer Dal Formation onlap the Caledonian basement. The progressive northwards truncation of the underlying succession and younging of the base of the Middle Jurassic strata probably reflect late Early Jurassic development of a rift dome in North-East Greenland and subsequent Middle Jurassic domal erosion, deflation and transgression (Surlyk 1977a, 1978) similar to the roughly contemporaneous dome in the North Sea (Sellwood \& Hallam 1974; Whiteman et al. 1975; Eynon 1981; Ziegler 1988; Underhill \& Partington 1993, 1994). The reality of Early Jurassic uplift has been confirmed on the basis of fission track thermochronology by Johnson \& Callagher (2000). In contrast, the Jameson Land area shows no evidence for Early Jurassic uplift and cooling (Mathiesen et al. 2000).

The Mesozoic succession was uplifted during the Neogene and is well-exposed, notably in Jameson Land, Milne Land, Traill $\varnothing$, Wollaston Forland, and Kuhn $\varnothing$ (Figs 1, 2). In this study, the focus is on the Upper Bajocian - Middle Callovian Pelion and Fossilbjerget Formations of Jameson Land which form a north- and westwards thickening wedge of shallow marine sand- 
stones and siltstones (Figs 1-3; Surlyk et al. 1973; Heinberg \& Birkelund 1984; Engkilde \& Surlyk 1993; Engkilde 1994; Surlyk \& Noe-Nygaard 2000; Larsen et al. 2003, this volume; Surlyk 2003, this volume).

The region has a long history of investigation and previous work on the Middle Jurassic succession of Jameson Land was largely focused on the general stratigraphy (Madsen 1904; Koch 1929, 1950; Rosenkrantz 1929, 1934, 1942; Spath 1932, 1947; Stauber 1940; Callomon 1959, 1961, 1970, 1972, 1993, 1994; Birkelund et al. 1971; Surlyk \& Birkelund 1972; Surlyk et al. 1973, 1993; Birkelund \& Perch-Nielsen 1976; Surlyk 1991). The only detailed study of the Middle Jurassic succession was by Heinberg \& Birkelund (1984), who analysed the trace fossil assemblages and facies patterns of the Pelion and Fossilbjerget Formations in Jameson Land.

The low gradient physiography, and general shallow water depth of the basin during Middle Jurassic times, made deposition very sensitive to even small changes in relative sea level. Such changes caused the shorelines to advance or retreat over tens to several hundreds of kilometres, with the formation of laterally extensive depositional units. The interpretation of changes in spatial distribution of the units through time is controlled by a detailed ammonite biostratigraphy and large-scale depositional variations and geometries.

The aim of the study is to establish depositional models and a sequence stratigraphic framework for the Middle Jurassic succession of Jameson Land. The architecture and facies trends through time of the PelionFossilbjerget couplet provide a well-exposed and welldated depositional analogue to contemporaneous major hydrocarbon reservoirs on the west Norway shelf and the Northern North Sea.

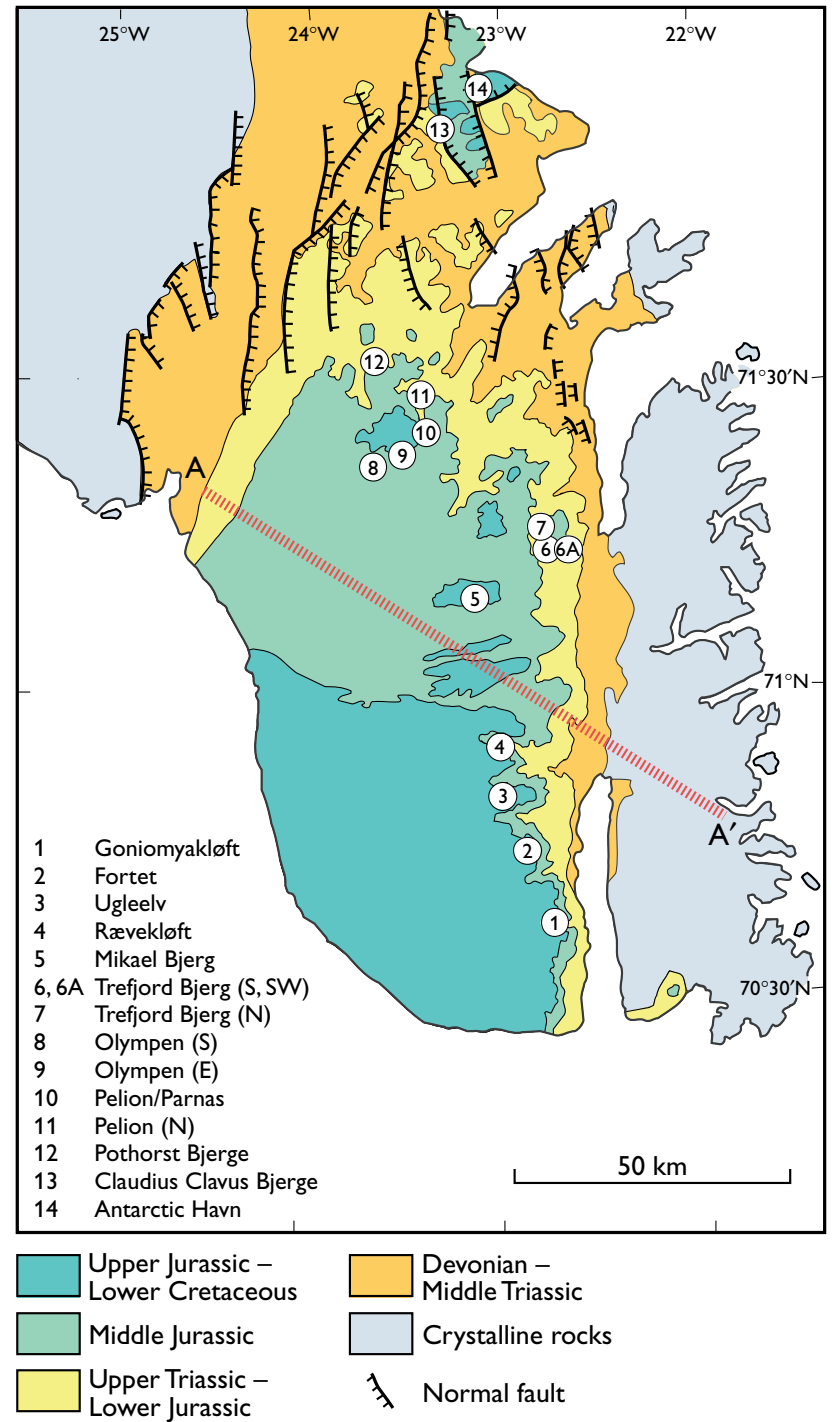

Fig. 2. Geological sketch map of Jameson Land. Numbers refer to localities described in the text. The section $\mathbf{A}-\mathbf{A}^{\prime}$ is shown in Fig. 3. Modified from Surlyk et al. (1973)
Fig. 3. NW-SE section of central Jameson Land (for location, see Fig. 2). The section shows the faulted, eastwards rising crystalline basement of Liverpool Land. The Mesozoic sediments onlapped the Liverpool Land crystalline basement or Permian sediments towards the east before removal by modern erosion. Modified from Larsen \& Marcussen (1992); M, Moho.
A

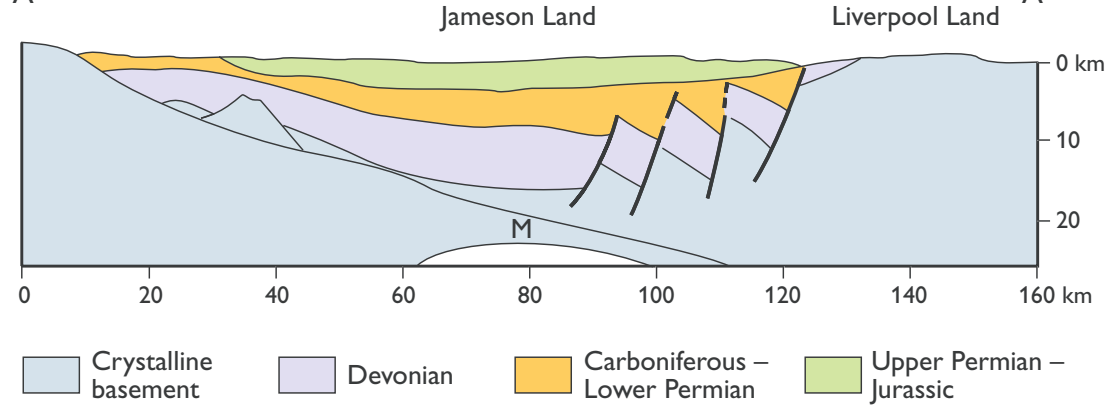




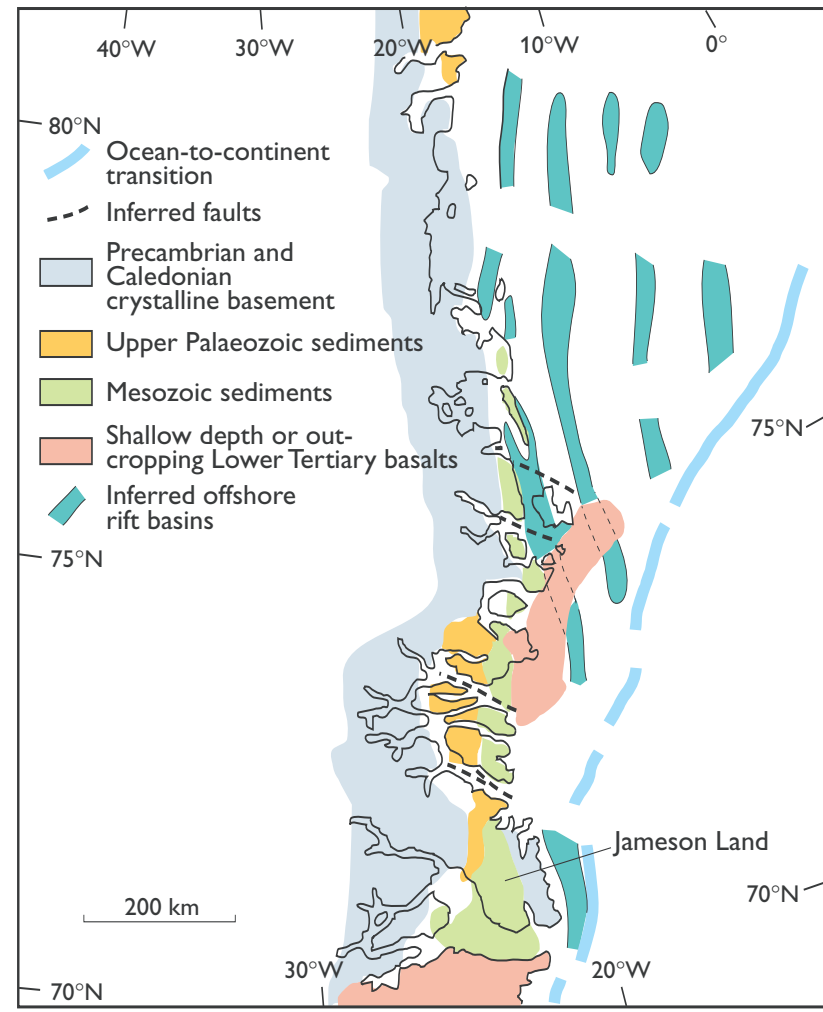

Fig. 4. Map showing the position of inferred Mesozoic sedimentary basins below the North-East Greenland shelf, based on aeromagnetic surveys and seismic data. Modified from Larsen (1990).

\section{Geological setting}

The Late Palaeozoic - Mesozoic extensional basins of East Greenland are exposed over $c .800 \mathrm{~km}$ in a southnorth direction, from Jameson Land and Milne Land in central East Greenland to Store Koldewey in North-East Greenland (Fig. 1). The Mesozoic deposits were largely deposited in two major basins, the Jameson Land and the Wollaston Forland Basins. The Jameson Land Basin is $c .140 \mathrm{~km}$ wide in south Jameson Land and Milne Land, narrowing northwards from Traill $\varnothing$ to Geographical Society $\varnothing$ and Hold with Hope (Figs 1, 3). The Wollaston Forland Basin is c. $50 \mathrm{~km}$ wide in the Clavering $\varnothing-$ Wollaston Forland area, and narrows northwards through Kuhn $\varnothing$ and Hochstetter Forland (Fig. 1). Marine Jurassic sandstones are found at Store Koldewey, and represent the western edge of a Mesozoic basin which continues offshore (Fig. 4; Surlyk et al. 1981, 1986; Surlyk 1990a).

The East Greenland basins formed the westernmost segment of the major north-south-oriented system of rift basins situated between Greenland and Norway (Fig. 5; Ziegler 1988; Larsen 1990; Doré 1991, 1992; Surlyk et al. 1993). At least $5 \mathrm{~km}$ of Upper Permian Mesozoic sediments were deposited in the Jameson Land Basin (Fig. 3). The Late Permian to Cretaceous basin evolution was characterised by post-rift thermal con-

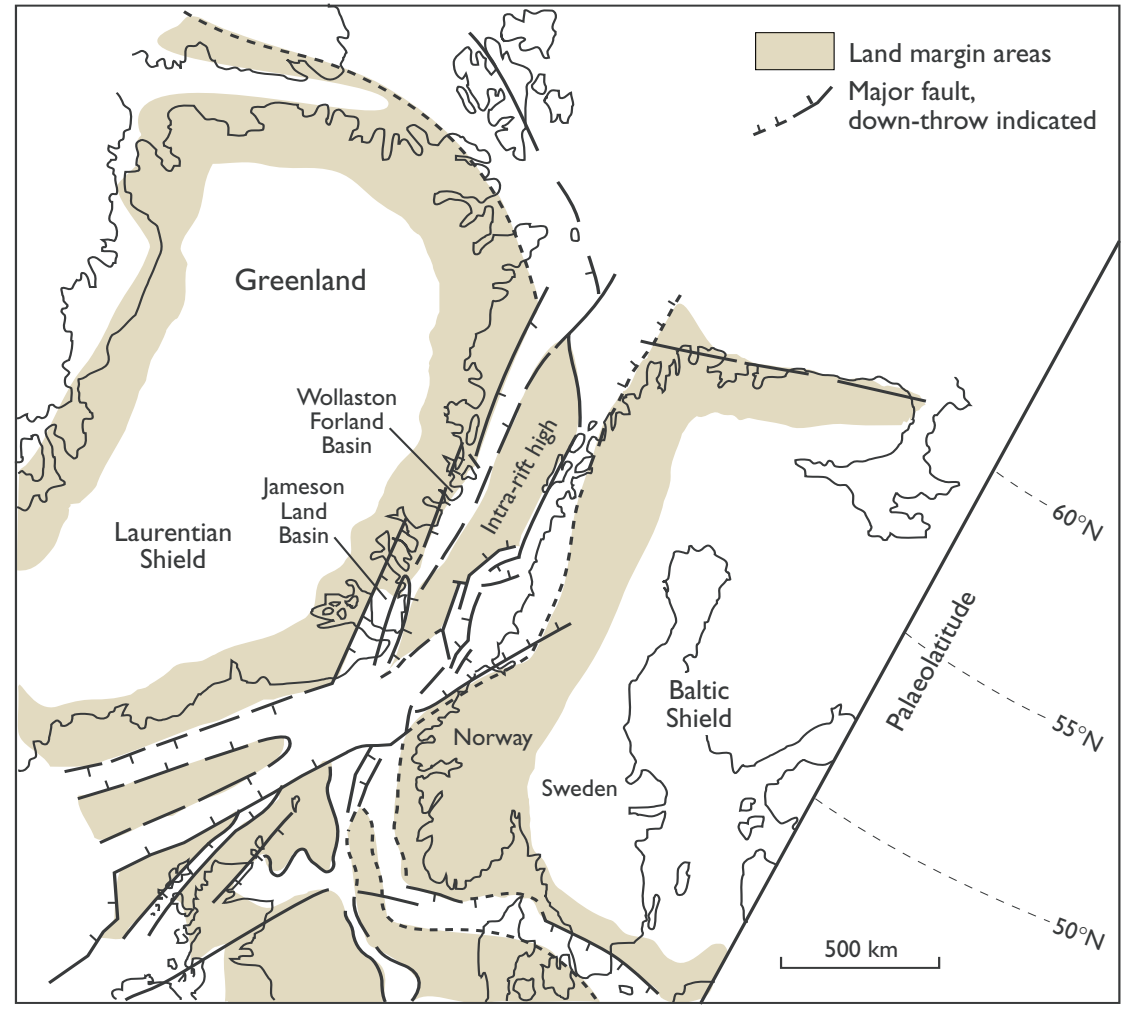

Fig. 5. Palaeogeographic map of the North Sea and northern North Atlantic region during the Middle Jurassic, showing the position of the basins in East Greenland, the Norwegian shelf and in the North Sea. Modified from Doré (1991). 
traction and sediment loading, following Late Palaeozoic rifting, interrupted by rift events in Late Permian - Early Triassic, Early Triassic, Middle-Late Jurassic, Early and Late Cretaceous times (Donovan 1953; Callomon 1972; Surlyk et al. 1973; Surlyk 1977b, 1990a, 1991, 2003, this volume; Clemmensen 1980; Surlyk \& Clemmensen 1983; Larsen 1990; Larsen \& Marcussen 1992; Price \& Whitham 1997; Surlyk \& Noe-Nygaard 2001a).

Major regional uplift of the areas north of Jameson Land took place in Early Jurassic times, probably close to the Early-Middle Jurassic transition. It was associated with changes in basin configuration and development of new drainage and transport patterns. The uplift has been related to the formation of a large rift dome north of Jameson Land, analogous to the North Sea dome developed at the triple junction between the Central Graben, the Viking Graben and the Witch Ground Graben (Surlyk 1977a, 1978). The uplift was marked by the sudden influx mainly from the north of large volumes of coarse-grained sediments in the northwards thickening succession (Surlyk et al. 1973, 1981; Surlyk \& Clemmensen 1983; Heinberg \& Birkelund 1984; Engkilde \& Surlyk 1993; Engkilde 1994). Similar Middle Jurassic uplift, succeeded by deposition of large volumes of coarse clastic deposits, is also documented from the mid-Norway shelf and the North Sea (Doré 1991, 1992). These deposits now form many of the most productive oil reservoirs in the North Sea and at the mid-Norway margin (Doré 1991; Mitchener et al. 1992; Cordey 1993).

The eastern margin of the Jameson Land Basin, represented by the present-day Liverpool Land, was a structural high in Mesozoic times that was periodically exposed and accumulated only a thin sediment cover (Figs 2, 3; Rosenkrantz 1942; Birkelund \& Perch-Nielsen 1976; Birkenmajer 1976; Clemmensen 1980; Surlyk et al. 1981; Dam \& Surlyk 1993, 1998). By Middle Jurassic times, north-westerly and westerly sediment sources were dominant (Bromley et al. 1970; Surlyk et al. 1973; Birkelund \& Perch-Nielsen 1976; Surlyk 1977b, 1991; Callomon \& Birkelund 1980). Fluvial and deltaic sediments occur at the base of the succession on Traill $\varnothing$ and Geographical Society $\varnothing$, and further north on Kuhn $\varnothing$ and Hochstetter Forland (Price \& Whitham 1997; Stemmerik et al. 1997; Alsgaard et al. 2003, this volume; Therkelsen \& Surlyk in press). The nature of the southern basin margin is not known, but seismic data suggest that Jurassic deposits extend south of Scoresby Sund (Larsen \& Marcussen 1992). The Middle Jurassic basin fill onlaps Precambrian and Caledonian crystalline basement along the western basin margin in Milne Land (Callomon \& Birkelund 1980; Larsen \& Marcussen 1992; Larsen et al. 2003, this volume).
The northwards termination of the Jurassic Liverpool Land basement high is not precisely known. An eastwards tilted fault-block was formed by Middle Jurassic rifting in south-eastern Traill $\varnothing$, and eastwards dips are also noted in north-east Jameson Land. This is opposite to all other Jurassic fault-blocks in East Greenland which show marked westwards dips and suggest direct marine communication towards the east in this area (Carr 1998; Vosgerau et al. in press b).

An important tectonic zone is situated in northern Jameson Land, separating the broad Jameson Land platform from the northern region which is characterised by Late Jurassic and Cretaceous tilted fault blocks. The cross fault zone probably coincides with a zone of NW-SE-trending deep-seated faults recognised by Dam et al. (1995). The fault zone was reactivated during Cenozoic basin uplift (Vischer 1943; Donovan 1953; Haller 1971; Surlyk 1977b; Surlyk et al. 1981, 1993; Larsen \& Marcussen 1992).

\section{Stratigraphy of the Pelion and Fossilbjerget Formations}

The Pelion and Fossilbjerget Formations (lower Vardekløft Group) form a north-westwards thickening wedge of Late Bajocian - Middle Callovian age, covering about $10 \mathrm{Ma}$ (Fig. 6). The formations overlie the Aalenian Lower Bajocian Sortehat Formation of the Neill Klinter Group in Jameson Land (Surlyk et al. 1973; Dam \& Surlyk 1998; Surlyk 2003, this volume, fig. 5). The base of the Pelion-Fossilbjerget couplet is a major sequence boundary, marked by a dramatic increase in the influx of coarse clastic sediments (Surlyk 1991, 2003, this volume; Surlyk et al. 1993; Dam \& Surlyk 1998). Farther north, on Traill $\varnothing$, the Pelion Formation overlies Upper Triassic redbeds of the Flemming Fjord Formation (Clemmensen 1980; Fig. 6). In Milne Land, at the western basin margin, Middle Jurassic sandstones of the Charcot Bugt Formation onlap crystalline basement (Callomon \& Birkelund 1980; Larsen et al. 2003, this volume). The top of the Pelion-Fossilbjerget couplet is a widespread condensed unit in southern Jameson Land. It is overlain by the Upper Callovian - Middle Oxfordian marine sandstones and mudstones of the Olympen Formation in northern Jameson Land and Traill $\varnothing$. In southern Jameson Land, the formations are overlain by condensed, distal deep-water mudstones of the Olympen Formation, followed by black mudstones and massive sandstones of the Upper Oxfordian - Lower Volgian Hareelv Formation (Surlyk 1987, 2003, this volume; 
Surlyk \& Noe-Nygaard 1998, 2001b; Larsen \& Surlyk 2003, this volume).

The Pelion-Fossilbjerget couplet thickens along the basin axis from $150 \mathrm{~m}$ in southern Jameson Land to $475 \mathrm{~m}$ in central and northern Jameson Land (Surlyk 1977b; Heinberg \& Birkelund 1984). The Pelion Formation thickens in the same direction from c. $50 \mathrm{~m}$ to about $400 \mathrm{~m}$. The very high thickness value, close to $700 \mathrm{~m}$, reported for the Pelion Formation at Antarctic Havn in northernmost Jameson Land (Heinberg \& Birkelund 1984), probably includes the Upper Callovian - Middle Oxfordian Olympen Formation. If this very poorly exposed and strongly faulted area is excluded, figure 25 of Heinberg \& Birkelund (1984) shows uniform thicknesses for all time slices from Mikael Bjerg in southern central Jameson Land and further north. The only significant decrease in thickness thus seems to take place in the region of sandstone pinch-out from Mikael Bjerg and further south.

The Pelion Formation consists mainly of shallow marine sandstones, which are overlain by, and pass southwards into deeper-water, offshore siltstones of the Fossilbjerget Formation (Fig. 6). The boundary between the two formations is strongly diachronous, and youngs

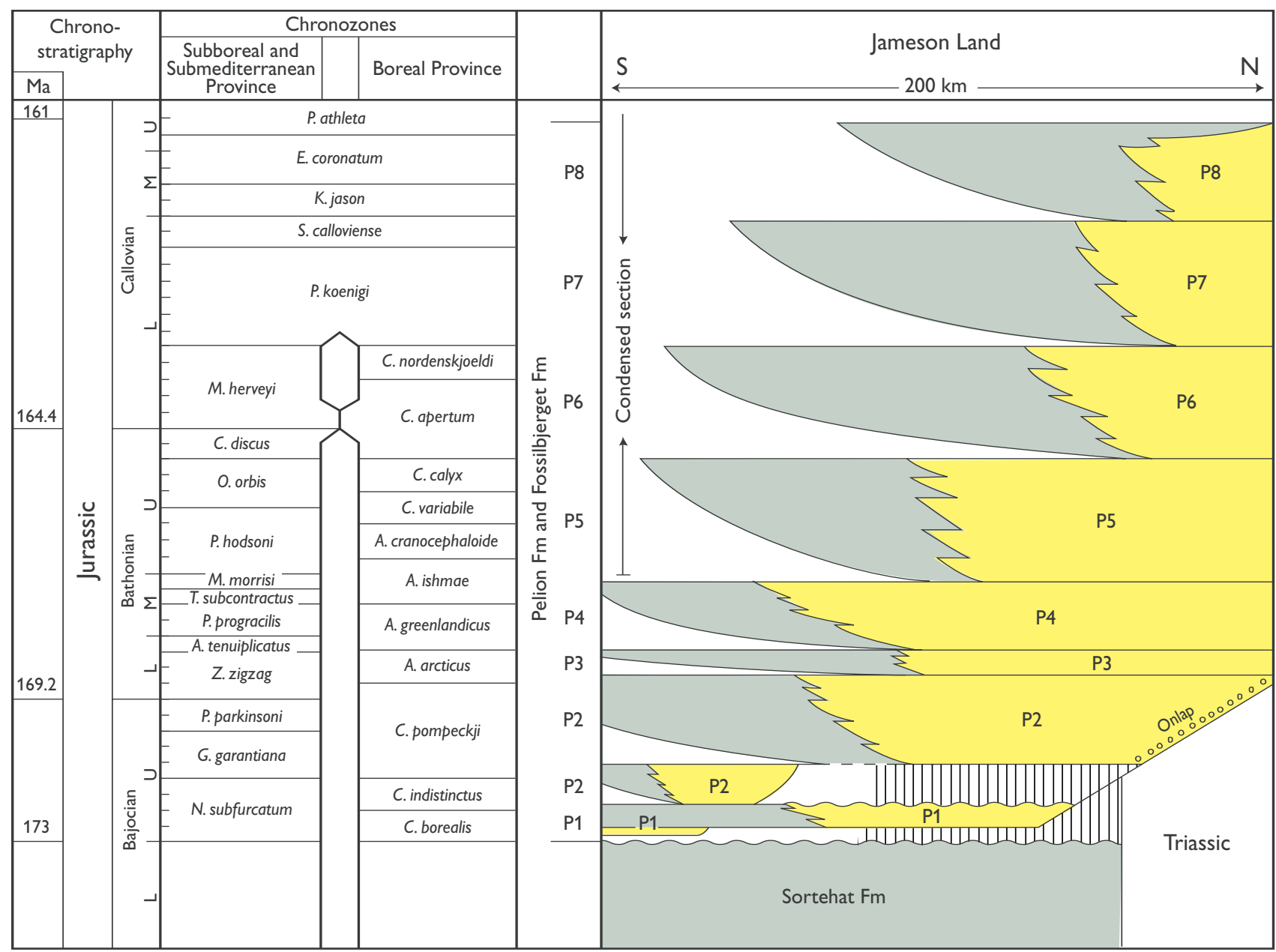

Shallow marine sandstones

Offshore siltstones, mudstones

\|\| Hiatus oooo Pebbles

Fig. 6. Chronostratigraphical scheme of the Pelion and Fossilbjerget Formations in Jameson Land (time-scale from Gradstein et al. 1994). P1-8 indicate composite depositional sequences. The number of high-order depositional sequences within the composite sequences is indicated by the saw-tooth pattern. The bulk sandstone parts of the composite sequences are late highstand deposits throughout central and northern Jameson Land. Thick deposits of the transgressive and early highstand systems tracts are predicted to exist in western and northern basin margin areas; such deposits are not shown in this figure, but indicated schematically on Fig. 36. Two lowstand units are shown in sequences P1 and P2. It should be noted that precise correlation to the Bajocian and Bathonian Stages of Europe is not yet possible, due to faunal provincialism; the Jurassic ammonite zonation is from Callomon (1993). The figure is based on fig. 2 in Surlyk (1991), with the addition of new data on the sequence stratigraphy. 
towards the north (Callomon 1959, 1993; Surlyk et al. 1973; Heinberg \& Birkelund 1984). The formations show a record of cyclic regressions and transgressions on several orders, and the boundary between the formations is thus not one continuous surface, but can be considered a series of shingled marine flooding surfaces, which cap individual progradational shallow offshore - shoreface units of the Pelion Formation. The geometry of the formations, large-scale textural gradients, and the observed palaeocurrent patterns, indicate that the main sediment influx was from the north and northwest, and sediment transport was mainly towards the south, along the basin axis.

The age relationships of the formations are based on a detailed ammonite biostratigraphy (Spath 1932; Callomon 1959, 1993; Surlyk et al. 1973). The PelionFossilbjerget couplet contains 16 ammonite zones, which are subdivided into 37 ammonite faunal horizons (Figs $6,7)$. Correlation with the European ammonite zonation in the Bajocian-Bathonian is not possible due to faunal provincialism (see Callomon 2003, this volume), and the precise age of the lower boundary of the Pelion Formation is uncertain but is tentatively placed in the earliest Late Bajocian (Fig. 6, left part; Callomon 1959, 1972, 1993; Surlyk et al. 1973). This is corroborated by ${ }^{87} \mathrm{Sr} /{ }^{86} \mathrm{Sr}$ values which suggest an early Late Bajocian age for the base of the Pelion Formation, by comparison with the strontium isotope curve of Jones et al. (1994) (M. Engkilde, unpublished data). The sedimentary organic content is dominantly terrestrially derived and poorly preserved. Abundant terrestrial pollen and spores occur throughout the formations together with subordinate marine dinoflagellate cysts that are abundant only at certain levels. Spores and pollen have contributed little to the biostratigraphic subdivision of the formations as most Middle and Late Jurassic species are long-ranging (M.D. Muir in: Sarjeant 1972; Lund \& Pedersen 1985). Dinoflagellate cysts have a higher stratigraphic potential which is not yet fully exploited (Sarjeant 1972; Smelror 1988; Larsen et al. 2003, this volume).

Marine connections between the Tethyan and Boreal Realms were re-established in the Callovian, and good correlations of the ammonite successions exist for the Callovian-Kimmeridgian interval (Fig. 6; Callomon 1959, 1972, 1993; Surlyk et al. 1973; Birkelund \& Perch-Nielsen 1976; Birkelund et al. 1984; Birkelund \& Callomon 1985).

The Pelion-Fossilbjerget couplet consists of eight composite sequences which are subdivided into 28 simple coarsening-upwards sequences (following the definition of Mitchum \& Van Wagoner 1991). The duration

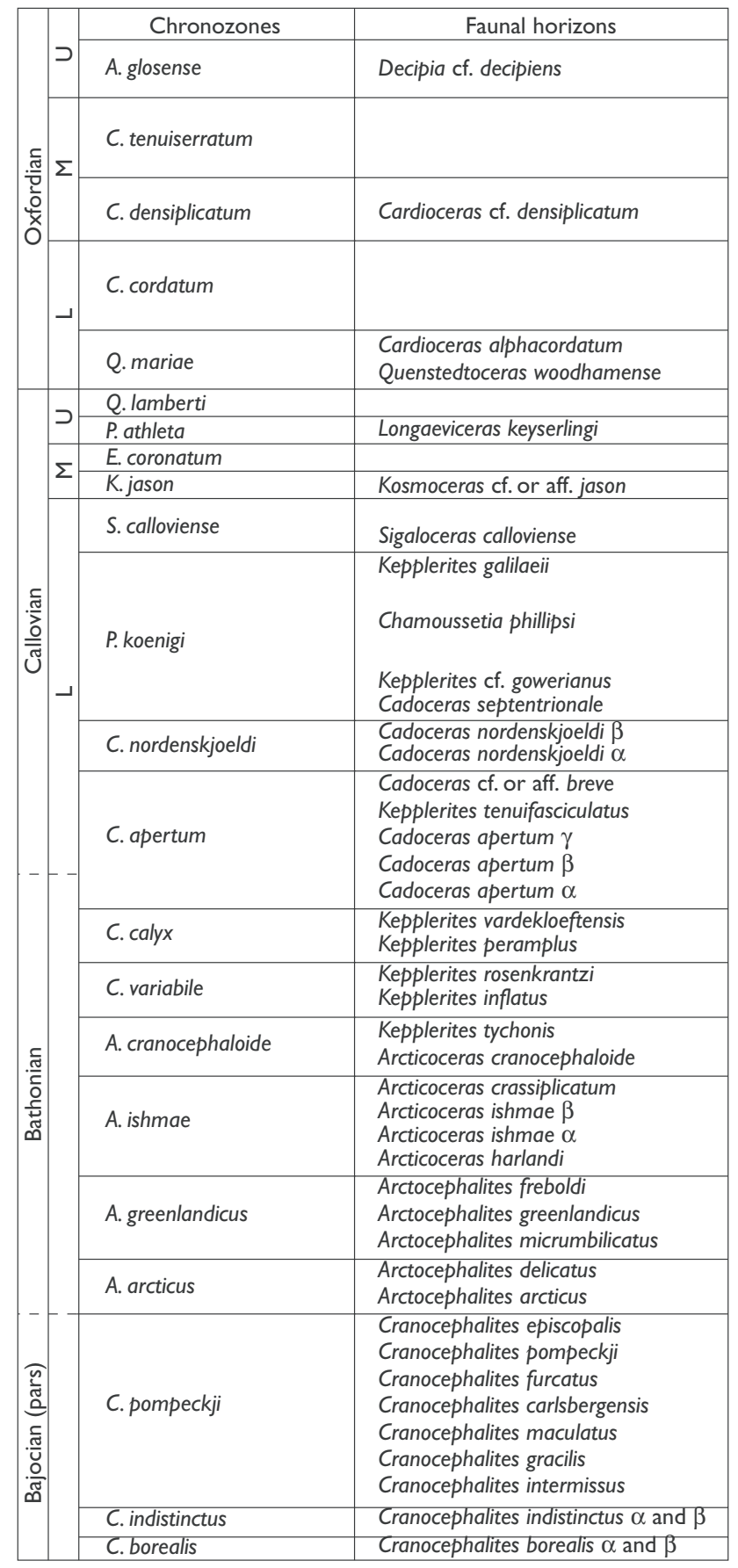

Fig. 7. Middle Jurassic faunal horizons and ammonite zones of East Greenland. Based on Callomon (1993).

of the composite sequences is one to a few million years, and several hundred thousand years for the simple sequences (Fig. 6). The Pelion and Fossilbjerget Formations form the lower part of the long-term regressive-transgressive Vardekløft Group (Surlyk \& Noe- 
Table 1. Facies classification

\begin{tabular}{|c|c|c|c|c|}
\hline $\begin{array}{l}\text { Sedimentary } \\
\text { facies }\end{array}$ & $\begin{array}{l}\text { Lithology, } \\
\text { thickness of beds }\end{array}$ & $\begin{array}{l}\text { Sedimentary } \\
\text { structures }\end{array}$ & $\begin{array}{l}\text { Grading and } \\
\text { grain size }\end{array}$ & Lower boundary \\
\hline 1 & $\begin{array}{l}\text { Coarse-grained } \\
\text { sandstone and } \\
\text { conglomerate. } \\
\text { Bedsets are } \\
<1 \text { m thick }\end{array}$ & $\begin{array}{l}\text { Planar and trough } \\
\text { cross-bedding or } \\
\text { structureless }\end{array}$ & $\begin{array}{l}\text { Normally graded } \\
\text { or non-graded. } \\
0.5 \mathrm{~mm}-10 \mathrm{~cm}\end{array}$ & $\begin{array}{l}\text { Erosional, relief up } \\
\text { to } 0.4 \mathrm{~m}\end{array}$ \\
\hline 2 & $\begin{array}{l}\text { Coarse-grained } \\
\text { sandstone. } \\
\text { Bedsets are } \\
<1 \text { m thick }\end{array}$ & $\begin{array}{l}\text { Low-angle, planar } \\
\text { cross-bedding or } \\
\text { structureless }\end{array}$ & $\begin{array}{l}\text { Non-graded. } \\
0.5-5 \mathrm{~mm}\end{array}$ & $\begin{array}{l}\text { Erosional, relief up } \\
\text { to } 0.4 \mathrm{~m}\end{array}$ \\
\hline 3 & $\begin{array}{l}\text { Fine- to medium- } \\
\text { grained sandstone. } \\
\text { Bedsets are } \\
<2 \text { m thick }\end{array}$ & $\begin{array}{l}\text { Trough cross-bedding, } \\
\text { indistinct lamination or } \\
\text { structureless }\end{array}$ & $\begin{array}{l}\text { Non-graded. } \\
0.1-0.5 \mathrm{~mm}\end{array}$ & $\begin{array}{l}\text { Erosional, relief up } \\
\text { to } 0.3 \mathrm{~m}\end{array}$ \\
\hline 4 & $\begin{array}{l}\text { Fine- to medium- } \\
\text { grained sandstone. } \\
\text { Bedsets are } \\
<2 \text { m thick }\end{array}$ & $\begin{array}{l}\text { Trough cross-bedding, } \\
\text { wavy bedding, } \\
\text { cross-lamination }\end{array}$ & $\begin{array}{l}\text { Non-graded. } \\
0.1-0.5 \mathrm{~mm}\end{array}$ & $\begin{array}{l}\text { Gradational from } \\
\text { underlying clinoform } \\
\text { association }\end{array}$ \\
\hline 5 & $\begin{array}{l}\text { (Calcareous) } \\
\text { siltstone. } \\
\text { Beds are } \\
<0.5 \mathrm{~m} \text { thick }\end{array}$ & $\begin{array}{l}\text { Structureless } \\
(100 \% \text { burrowing) } \\
\text { or planar lamination } \\
\text { with minor burrowing }\end{array}$ & $\begin{array}{l}\text { Non-graded. } \\
0.05-0.25 \mathrm{~mm}\end{array}$ & $\begin{array}{l}\text { Erosional, wavy, } \\
\text { relief }<10 \mathrm{~cm}\end{array}$ \\
\hline 6 & $\begin{array}{l}\text { Silty, fine-grained } \\
\text { sandstone. } \\
\text { Bedsets are } \\
0.3-10 \text { m thick }\end{array}$ & $\begin{array}{l}\text { Planar lamination, } \\
\text { hummocky cross- } \\
\text { stratification, } \\
\text { prod marks }\end{array}$ & $\begin{array}{l}\text { Inversely graded } \\
\text { or non-graded. } \\
0.1-2 \mathrm{~mm}\end{array}$ & $\begin{array}{l}\text { Planar or wavy, } \\
\text { relief }<10 \mathrm{~cm}\end{array}$ \\
\hline 7 & $\begin{array}{l}\text { Fine- to coarse- } \\
\text { grained sandstone. } \\
\text { Bedsets are } \\
0.1-6 \mathrm{~m} \text { thick }\end{array}$ & $\begin{array}{l}\text { Cross-lamination, } \\
\text { wavy-bedding, } \\
\text { local cross-bedding }\end{array}$ & $\begin{array}{l}\text { Inversely graded } \\
\text { or non-graded. } \\
0.1-2 \mathrm{~mm}\end{array}$ & $\begin{array}{l}\text { Erosional, wavy, } \\
\text { relief }<6 \mathrm{~cm}\end{array}$ \\
\hline 8 & $\begin{array}{l}\text { Fine- to medium- } \\
\text { grained sandstone. } \\
\text { Bedsets are } \\
<6 \text { m thick }\end{array}$ & $\begin{array}{l}\text { Horizontal to low- } \\
\text { angle inclined } \\
\text { bedding, swaley } \\
\text { cross-stratification }\end{array}$ & $\begin{array}{l}\text { Inversely graded } \\
\text { or non-graded. } \\
0.1-0.5 \mathrm{~mm}\end{array}$ & Gradational \\
\hline 9 & $\begin{array}{l}\text { Fine- to coarse- } \\
\text { grained sandstone } \\
\text { and conglomerate. } \\
\text { Bedsets are up to } \\
35 \text { m thick }\end{array}$ & $\begin{array}{l}\text { Cross-lamination, } \\
\text { cross-bedding, } \\
\text { wavy-bedding or } \\
\text { structureless }\end{array}$ & $\begin{array}{l}\text { Non-graded. } \\
0.1-10 \mathrm{~cm}\end{array}$ & $\begin{array}{l}\text { Structurally and } \\
\text { texturally gradational } \\
\text { or erosional }\end{array}$ \\
\hline 10 & $\begin{array}{l}\text { Siltstones and fine- } \\
\text { grained sandstone. } \\
\text { Depositional units } \\
\text { are up to } 10 \mathrm{~m} \text { thick }\end{array}$ & $\begin{array}{l}\text { Planar lamination, } \\
\text { hummocky cross- } \\
\text { stratification or } \\
\text { structureless }\end{array}$ & $\begin{array}{l}\text { Inversely graded } \\
\text { or non-graded. } \\
0.005-0.25 \mathrm{~mm}\end{array}$ & $\begin{array}{l}\text { Non-erosional, } \\
\text { planar }\end{array}$ \\
\hline
\end{tabular}

Nygaard 2000; Surlyk 2003, this volume). In the Jameson Land Basin, the age of the composite sequences is wellestablished to ammonite zone or subzone level. Many of the simple sequences are also biostratigraphically dated by ammonites.

\section{Sedimentology of the Pelion and Fossilbjerget Formations}

Ten sedimentary facies (Table 1, facies 1-10) are identified in the Pelion and Fossilbjerget couplet in Jameson Land. The facies occur as single beds, lenses, or up to $40 \mathrm{~m}$ thick bed-sets. All facies were deposited in marine 


\begin{tabular}{|c|c|c|c|c|}
\hline Upper boundary & $\begin{array}{l}\text { Fossils and } \\
\text { bioturbation }\end{array}$ & $\begin{array}{l}\text { Depositional } \\
\text { processes }\end{array}$ & Facies association & $\begin{array}{l}\text { Depositional } \\
\text { environment }\end{array}$ \\
\hline $\begin{array}{l}\text { Erosional, planar or } \\
\text { wavy }\end{array}$ & $\begin{array}{l}\text { Fragmented belemnites, } \\
\text { bivalves, and ammonites. } \\
\text { Non-bioturbated }\end{array}$ & $\begin{array}{l}\text { Lag formation by marine } \\
\text { wave-ravinement }\end{array}$ & $\begin{array}{l}\text { Shoreface }(A) \\
\text { Estuarine }(B) \\
\text { Tidal inlet (C) }\end{array}$ & $\begin{array}{l}\text { Shoreface to shallow } \\
\text { offshore, above storm } \\
\text { wave-base }\end{array}$ \\
\hline $\begin{array}{l}\text { Erosional, planar or } \\
\text { wavy }\end{array}$ & $\begin{array}{l}\text { Fragmented belemnites } \\
\text { and bivalves. } \\
\text { Vertical burrows }\end{array}$ & $\begin{array}{l}\text { Lag formation by marine } \\
\text { wave-ravinement }\end{array}$ & $\begin{array}{l}\text { Shoreface (A) } \\
\text { Tidal inlet (C) } \\
\text { Sand sheet (D) }\end{array}$ & $\begin{array}{l}\text { Shoreface to shallow } \\
\text { offshore, above storm } \\
\text { wave-base }\end{array}$ \\
\hline Erosional, planar & Vertical burrows & $\begin{array}{l}\text { Lag formation by marine } \\
\text { ravinement followed by } \\
\text { shallow offshore wave } \\
\text { reworking }\end{array}$ & $\begin{array}{l}\text { Shoreface }(A) \\
\text { Sand sheet }(D)\end{array}$ & $\begin{array}{l}\text { Shoreface to shallow } \\
\text { offshore, above storm } \\
\text { wave-base }\end{array}$ \\
\hline Erosional, planar & $\begin{array}{l}\text { Belemnites (partly } \\
\text { fragmented) }\end{array}$ & $\begin{array}{l}\text { Sand sheet formation by } \\
\text { wave reworking }\end{array}$ & Sand sheet (D) & $\begin{array}{l}\text { Shallow offshore, } \\
\text { above storm wave-base }\end{array}$ \\
\hline $\begin{array}{l}\text { Non-erosional, } \\
\text { planar }\end{array}$ & $\begin{array}{l}\text { Belemnites, bivalves, } \\
\text { ammonites, gastropods. } \\
\text { Network-forming burrows }\end{array}$ & $\begin{array}{l}\text { Suspension fall-out, } \\
\text { precipitation of } \\
\text { bio-carbonate and } \\
\text { hardground formation }\end{array}$ & $\begin{array}{l}\text { Clinoform (E) } \\
\text { Offshore }(F)\end{array}$ & $\begin{array}{l}\text { Offshore, below } \\
\text { storm wave-base }\end{array}$ \\
\hline $\begin{array}{l}\text { Structurally and } \\
\text { texturally gradational } \\
\text { or erosional }\end{array}$ & $\begin{array}{l}\text { Bivalves, belemnites. } \\
\text { Horizontal and } \\
\text { vertical burrows }\end{array}$ & $\begin{array}{l}\text { Suspension fall-out, } \\
\text { traction and agitation } \\
\text { by shoaling waves }\end{array}$ & Offshore (F) & $\begin{array}{l}\text { Offshore, close to } \\
\text { storm wave-base }\end{array}$ \\
\hline $\begin{array}{l}\text { Structurally and } \\
\text { texturally gradational } \\
\text { or erosional }\end{array}$ & $\begin{array}{l}\text { Bivalves, belemnites. } \\
\text { Horizontal and } \\
\text { vertical burrows }\end{array}$ & $\begin{array}{l}\text { Suspension fall-out, } \\
\text { traction and agitation } \\
\text { by waves }\end{array}$ & Shoreface (A) & $\begin{array}{l}\text { Shoreface, above fair- } \\
\text { weather wave-base }\end{array}$ \\
\hline $\begin{array}{l}\text { Structurally and } \\
\text { texturally gradational } \\
\text { or erosional }\end{array}$ & $\begin{array}{l}\text { Bivalves, belemnites. } \\
\text { Horizontal and } \\
\text { vertical burrows }\end{array}$ & $\begin{array}{l}\text { Suspension fall-out from } \\
\text { sheet-flows, agitation } \\
\text { by waves }\end{array}$ & Shoreface (A) & $\begin{array}{l}\text { Shoreface, from } \\
\text { above storm wave-base } \\
\text { to foreshore }\end{array}$ \\
\hline $\begin{array}{l}\text { Erosional, wavy, } \\
\text { with relief }<40 \mathrm{~cm} \text {, } \\
\text { or planar }\end{array}$ & $\begin{array}{l}\text { Fragmented bivalves, } \\
\text { belemnites and ammonites. } \\
\text { Horizontal and } \\
\text { vertical burrows }\end{array}$ & $\begin{array}{l}\text { Traction and agitation by } \\
\text { waves, coast-parallel } \\
\text { currents }\end{array}$ & $\begin{array}{l}\text { Shoreface (A) } \\
\text { Estuarine (B) } \\
\text { Tidal inlet (C) } \\
\text { Sand sheet (D) } \\
\text { Clinoform (E) }\end{array}$ & $\begin{array}{l}\text { Shoreface to shallow } \\
\text { offshore, from below } \\
\text { storm wave-base to } \\
\text { above fair-weather } \\
\text { wave-base }\end{array}$ \\
\hline $\begin{array}{l}\text { Non-erosional, } \\
\text { planar or erosional } \\
\text { with relief }<10 \mathrm{~cm}\end{array}$ & $\begin{array}{l}\text { Belemnites, ammonites, } \\
\text { bivalves, gastropods, } \\
\text { arthropods and corals. } \\
\text { Horizontal and } \\
\text { vertical burrows }\end{array}$ & $\begin{array}{l}\text { Suspension fall-out, } \\
\text { minor agitation and } \\
\text { traction by waves }\end{array}$ & Offshore (F) & $\begin{array}{l}\text { Offshore, below or } \\
\text { close to storm } \\
\text { wave-base }\end{array}$ \\
\hline
\end{tabular}

environments, as indicated by body and trace fossil content, sedimentary structures and the facies associations. The facies are described and interpreted in Table 1.

Six facies associations (A-F) are recognised. They are characterised by a systematic vertical stacking of genetically related facies. The facies changes reflect the development through time of the depositional environment and its relationship to the initial bathymetry, relative sealevel changes, sediment influx and grain-size distribution. The facies associations form genetic units and do not include any major hiatuses. They are generally bounded by regionally extensive sequence stratigraphic key surfaces (discussed in the sequence stratigraphy section). The facies associations represent two large-scale 
depositional environments: (1) the upper shoreface to offshore transition zone, and (2) the offshore. Facies associations A-E were deposited in shoreface and shallow offshore transition zone environments: A, shoreface association; $\mathrm{B}$, estuarine association; $\mathrm{C}$, tidal inlet association; D, sand sheet association; E, clinoform association. The offshore association (F) was deposited in a deeper-water environment.

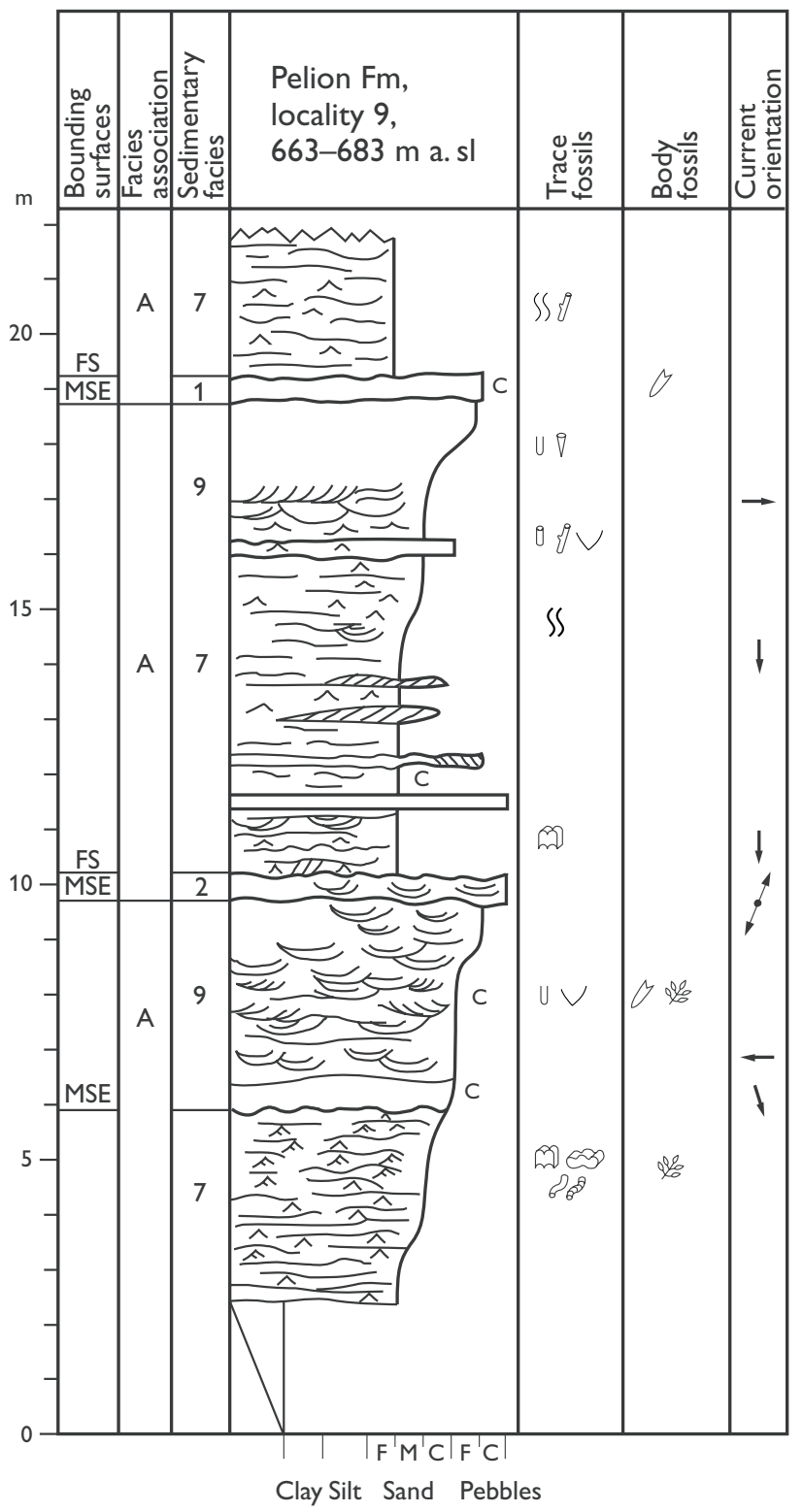

Fig. 8. Pebbly shoreface association (A), consisting of heavily burrowed middle and upper shoreface deposits, dominated by wave-formed trough cross-bedding. The very coarse-grained nature of the deposits suggests a nearby fluvial source. Pelion Formation, locality 9 (Fig. 2). The association belongs to sequence P1 (Fig. 6). The accompanying legend (facing page) also applies to the subsequent sedimentary logs in the paper; $\mathbf{m}$ a. sl, metres above sea level.

\section{A. Shoreface association}

The shoreface association consists of fine-grained to pebbly sandstones and conglomerates and forms coarsening-upwards units, 5-12 $\mathrm{m}$ thick (Figs 8-11). Stacked, amalgamated shoreface units are common and may reach $40 \mathrm{~m}$ in thickness. The foreshore to upper shoreface, middle shoreface, and lower shoreface to offshore transition

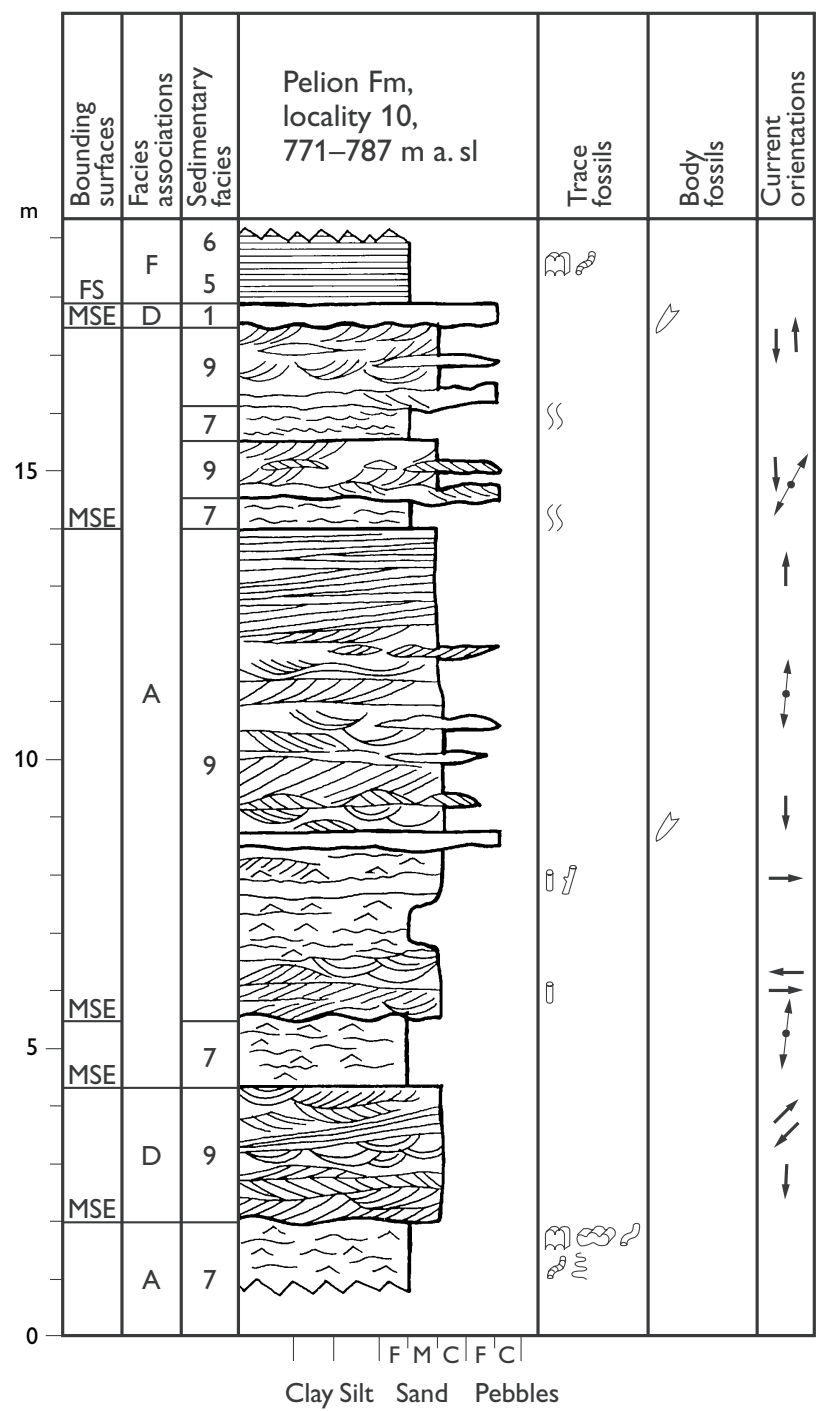

Fig. 9. Sand sheet association (D) overlain by shoreface association (A). The shoreface association consists of $8 \mathrm{~m}$ of mixed waveand current-influenced middle shoreface sandstones (4-12 m), overlain by $2 \mathrm{~m}$ of upper shoreface swash/surf-laminated sandstones. The top is formed by amalgamated upper shoreface deposits (14-18 m). The abundance of conglomerate beds suggests a nearby fluvial source. Pelion Formation, locality 10 (Fig. 2). The association belongs to sequence P2 (Fig. 6). For legend, see facing page. 


\section{Sedimentary structures}

Trough cross-bedding

Planar cross-bedding

Swaley cross-stratification

Hummocky cross-stratification

Structureless

ڤA Current ripple cross-lamination

Wave ripples and wave ripple

cross-lamination

Planar bedding

Planar lamination

Indistinct lamination

Wavy bedding

\section{Palaeocurrents, miscellaneous}

Foreset orientation

$4^{\circ}$ Orientation and dip of inclined master bedding

Bipolar wave ripple
foreset orientation

000 Pebbles

$|\||||$ Dolerite sill

C Coal drapes and lenses

\section{Trace fossils}

$\checkmark$ Monocraterion tentaculatum

U Diplocraterion habichi

i) Skolithos isp.

ff Ophiomorpha nodosa

(m) Gyrochorte comosa

es) Curvolithus multiplex

潧= Phoebichnus trochoides

8 Planolites vulgaris

§. Helminthopsis magna

Taenidium serpentinum

5) Rhizocorallium irregulare

r Thalassinoides suevica

Phycodes isp.

$\checkmark$ Arenicolites isp.

S-SSS Degree of bioturbation
Body fossils

¿ Belemnite

(9) Ammonite

Bivalve

Plant fragments and petrified wood

\section{Bounding surfaces}

MSE Marine surface of erosion

FS Flooding surface

\section{Facies associations}
A Shoreface
B Estuarine
C Tidal inlet
D Sand sheet
E Clinoform
F Offshore

\section{Sedimentary facies}

1 Non-bioturbated fossiliferous, coarse-grained sandstone and conglomerate lag

2 Bioturbated coarse-grained sandstone lag

3 Fine- to medium-grained structureless to faintly laminated or cross-bedded sandstone

4 Cross-bedded, cross-laminated and wavy-bedded fine- to medium-grained sandstone

5 Heavily burrowed calcareous siltstone and fossilliferous laminated siltstone

6 Laminated silty, fine-grained sandstone

7 Fine- to coarse-grained, cross-laminated sandstone

8 Fine- to medium-grained, low-angle inclined and horizontally bedded sandstone

9 Cross-laminated, cross-bedded and structureless fine- to coarse-grained sandstone and conglomerate

10 Offshore facies: laminated to structureless siltstone 
zone deposits are dealt with separately due to the complex vertical and lateral relationships between facies. Shoreface deposits dominate the sedimentary record throughout the Pelion Formation.

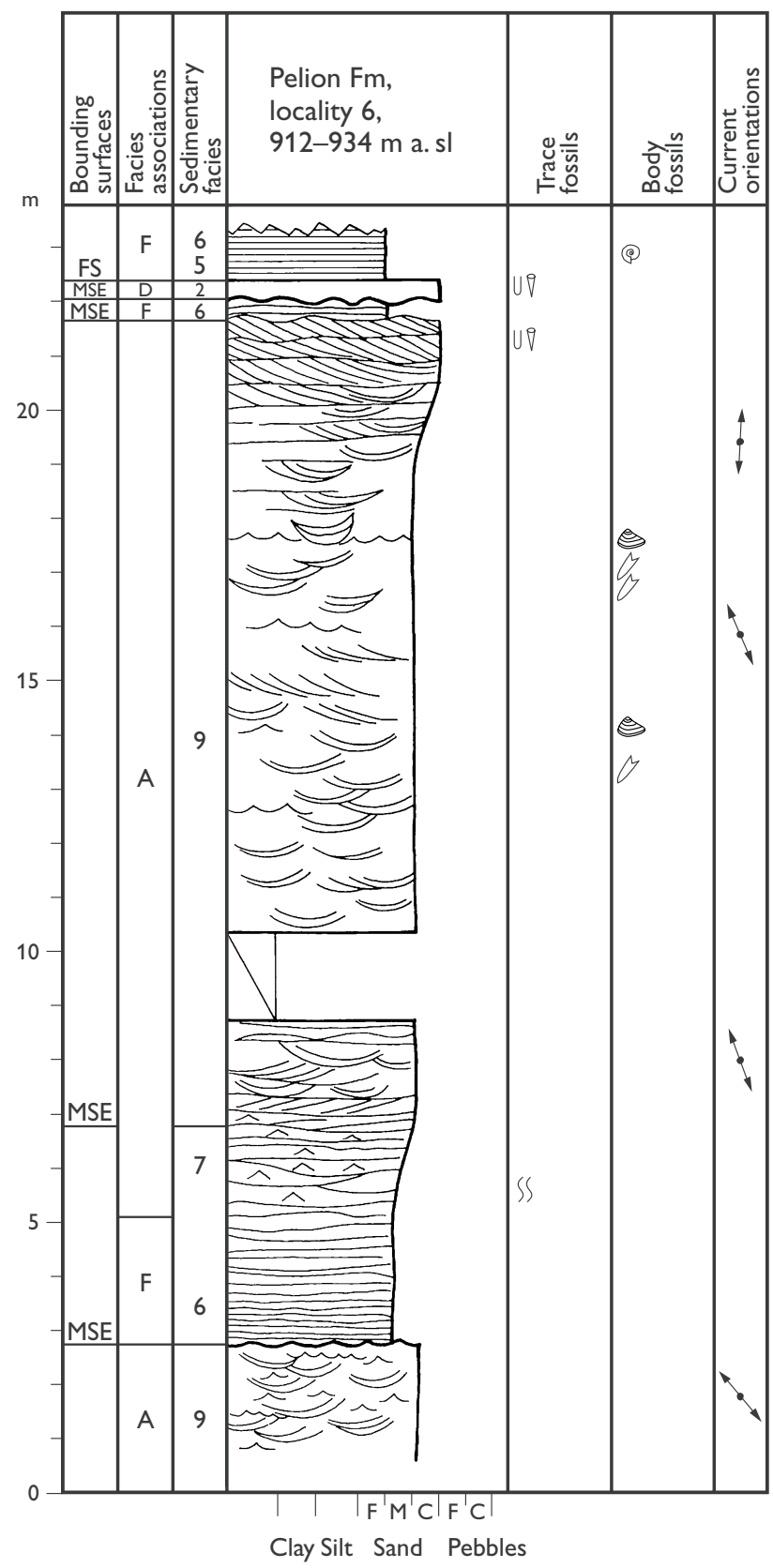

Fig. 10. Wave-dominated shoreface association (A). The upper part shows swaley cross-stratification, with wave-formed surfaces locally with concentrations of bivalves. The uppermost part of the upper shoreface deposits is dominated by unimodally oriented cross-bedding, formed by predominantly southwards (offshore) migrating bars. Pelion Formation, locality 6 (Fig. 2). The association belongs to sequence P1 (Fig. 6). For legend, see p. 823.

\section{Foreshore and upper shoreface}

Foreshore and upper shoreface deposits consist of fineto coarse-grained, cross-laminated, cross-bedded and structureless sandstones, and structureless or cross-bedded conglomerates (facies 9). The deposits form units, 5-40 m thick. Units thicker than 5-10 m consist of amalgamated upper shoreface deposits. Marine body and trace fossils occur throughout and terrestrial deposits have not been recognised. Trace fossils are dominated by vertical burrows. Two types of upper shoreface deposits are recognised: barred and non-barred upper shoreface sandstones (Figs 8-11).

Barred upper shoreface deposits vary from pebbly, poorly to well sorted medium- or fine-grained sandstones; grain-size variations between individual beds may be large. Sedimentary structures include a mixture of wave- and current-formed cross-lamination and crossbedding, and most sandstones show an intricate mixture of swaley cross-beds, rip-channel fills, shore-parallel trough fills, bar cross-beds, wave-surf and swash bar deposits. Wave-rippled sheets occur interbedded (Figs 12-15). Locally, cross-bed foresets show thin mudstone and siltstone drapes, and herringbone cross-bedding with bundled build-up of foresets also occurs. The lower boundary of the foreshore and upper shoreface deposits is sharp, erosional or gradational. The erosionally-based deposits show a low-angle master bedding, dipping up to $6^{\circ}$ towards the south or south-east. The gradationally-based deposits show a horizontal to low-angle inclined master bedding, dipping less than $1-2^{\circ}$ in a southerly direction. Palaeocurrent directions show a wide scatter, although southwards orientations dominate (Fig. 16). The deposits are capped by a marine surface of erosion, commonly overlain by a thin, coarsegrained sandstone or pebble lag, interpreted as genetically belonging to the overlying depositional unit (Figs 17-19). The pebble lags consist of discoid or rounded quartz pebbles, $0.5-10 \mathrm{~cm}$ in diameter, intraformational sandstone and mudstone clasts, fragmented belemnites and bivalves, and in some cases also subangular extraformational rock fragments.

Fine- to medium-grained, barred upper shoreface sandstones show the highest diversity of trace fossils, including Diplocraterion habichi, Monocraterion tentaculatum, Ophiomorpha nodosa, Planolites isp., Thalassinoides suevica, Skolithos linearis and Curvolithos multiplex of the Diplocraterion habichi and Curvolithos ichnocoenoses of Heinberg \& Birkelund (1984). The uppermost part of the upper shoreface units commonly shows dense burrowing by Diplocraterion habichi, 
Fig. 11. A section (15 $\mathrm{m}$ thick) through the shoreface association (A). As illustrated on the schematic log, lower shoreface to offshore deposits $(\mathbf{3}, \mathbf{4})$ gradually coarsen-upwards into strongly burrowed middle shoreface deposits (2), erosionally overlain by trough crossbedded upper shoreface deposits (1). The upper bounding surface of the shoreface association is a wave-cut marine surface of erosion (dashed line, MSE). It is overlain by heavily burrowed, shallow offshore deposits. Pelion Formation, locality 9 (Fig. 2).

Fig. 12. Middle to upper shoreface sandstones showing surf-zone laminated deposits (1), wave-rippled deposits (2), swash-bar deposits (3), and deposits representing lateral migration of runnels, or rip-channel troughs (4). Pen (centre, left) is $14 \mathrm{~cm}$ long. Pelion Formation, locality 9 (Fig. 2).
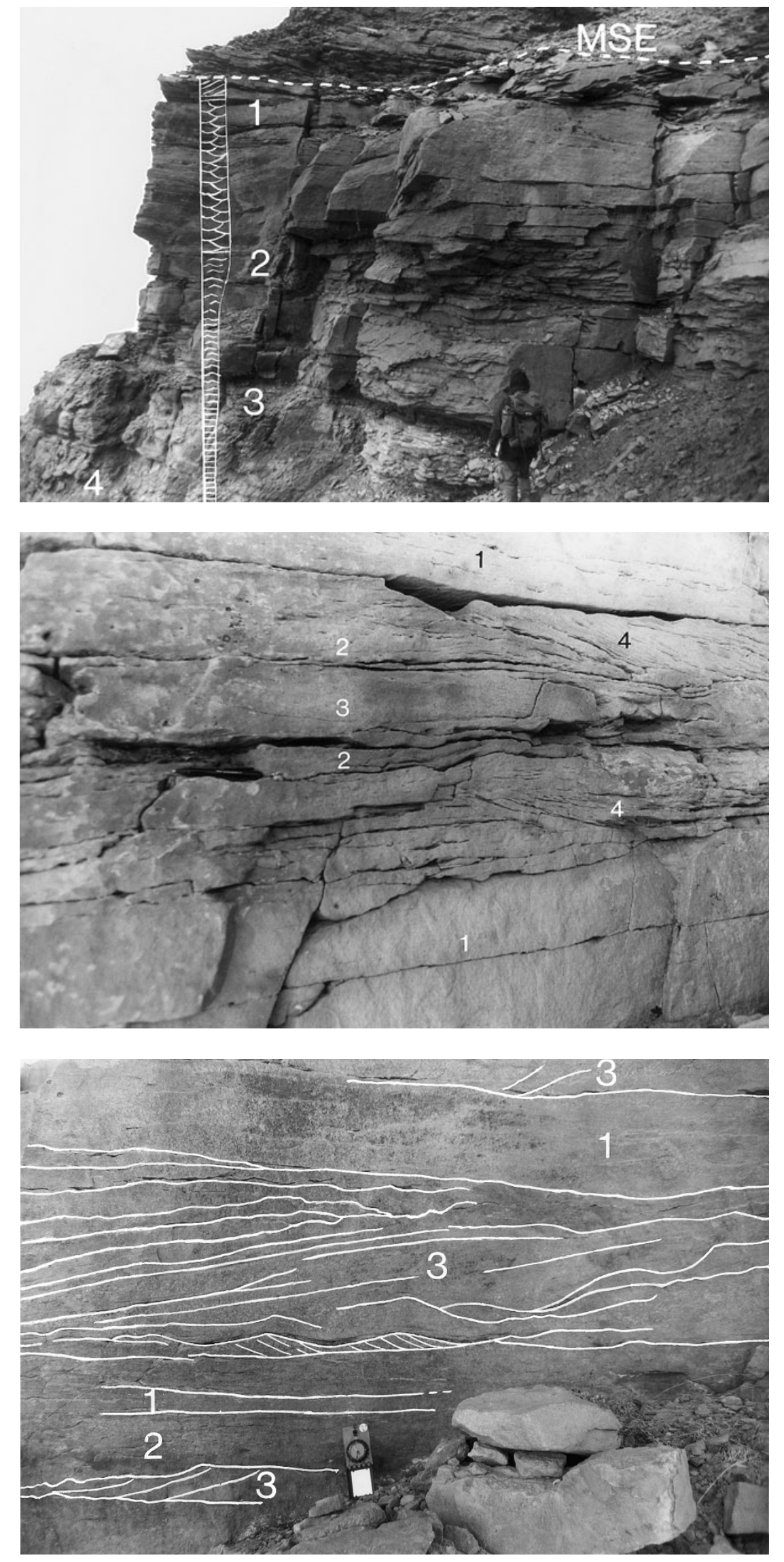

Fig. 13. Medium-grained sandstones of a barred, upper shoreface, showing surfand swash-zone laminated (1), waverippled (2), and swash-bar deposits (3). The bar deposits show rippled reactivation surfaces, and are interpreted as having formed during waning storm conditions. Transparent part of compass is $11 \mathrm{~cm}$ long. Pelion Formation, locality 10 (Fig. 2). 

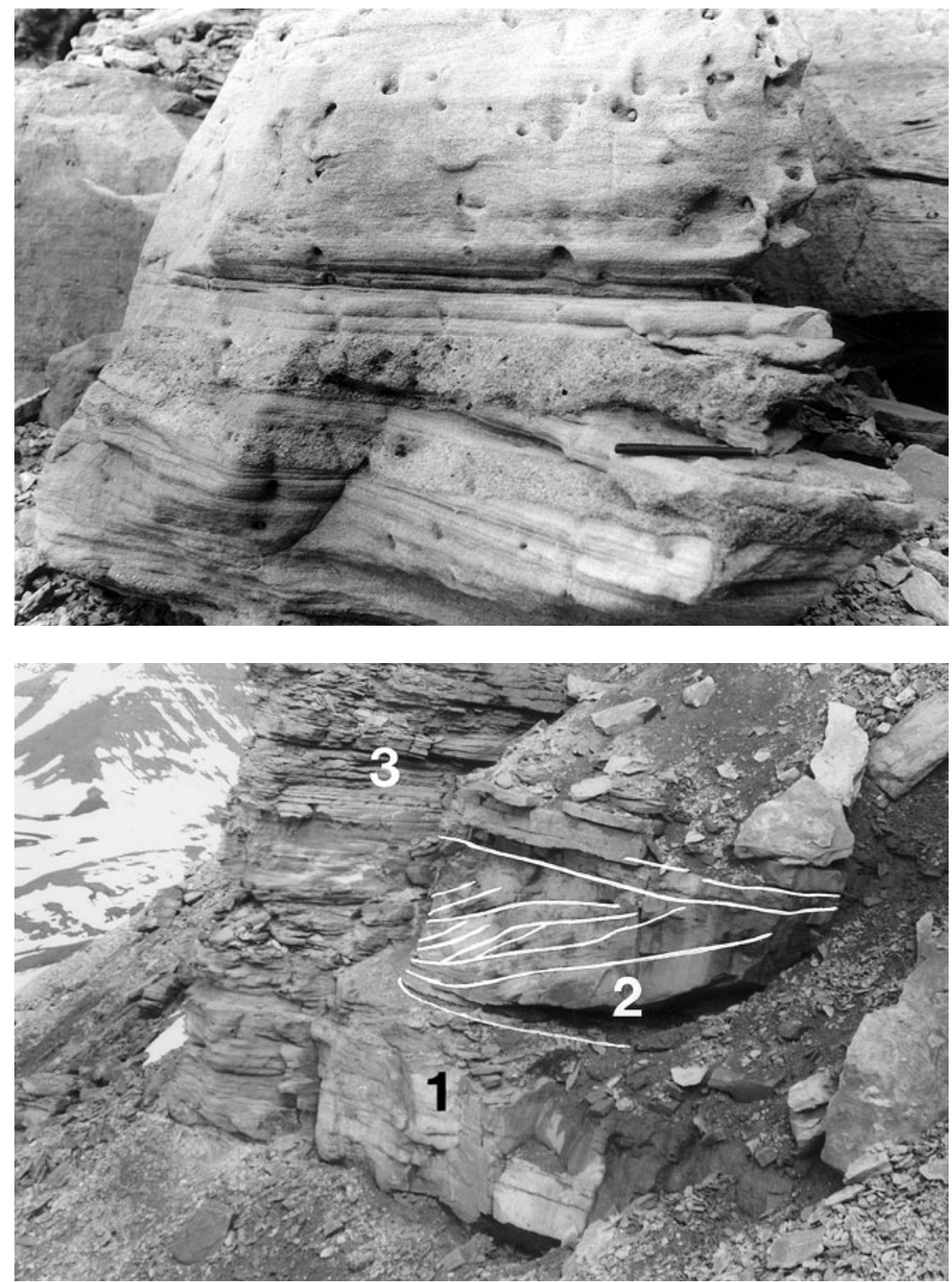

Fig. 14. Foreshore deposits with parallel to low-angle, inclined, fine- to mediumgrained sandstones of fair-weather origin, erosionally overlain by coarse-grained, belemnite-rich, pebbly storm sandstones. Bioturbation by Ophiomorpha nodosa . Pen (lower, right) is $14 \mathrm{~cm}$ long. Pelion Formation, locality 9 (Fig. 2).

Fig. 15. Sandstones showing horizontal to low-angle inclined bedding (1), cut by south to south-east oriented large-scale rip-channel trough fill (2), showing epsilon-infill pattern, caused by eastwards lateral migration of the rip-channel. $\mathbf{3}$, wave-rippled beds. Pelion Formation, locality 9 (Fig. 2). Total thickness of (2) is c. $2 \mathrm{~m}$.
Monocraterion tentaculatum and/or Ophiomorpha nodosa of the Diplocraterion habichi and Ophiomorpha ichnocoenoses (Heinberg \& Birkelund 1984). Body fossils are mainly preserved in the pebble beds, including fragmented belemnites, ammonites and bivalves.

The trace fossil assemblage, pebble and conglomerate lenses, low-angle master bedding, with a dip direction parallel to the dominant current orientations of the ripchannel and bar deposits, and the generally complex bedding suggest a highly dynamic foreshore to upper shoreface environment (Clifton 1969, 1976; Davis \& Fox 1972; Dörjes \& Hertweck 1975; Ekdale et al. 1984; Curran 1985). Mudstone-draped foresets and herringbone cross-bedding with bundled build-up of foresets suggest that reversing tidal currents were active, at least locally. Tidal processes seem in general to have been overprinted by wave action and associated wave-induced currents. The wave-ripple cross-laminated sediments represent aggradational fair-weather deposits, whereas cross-beds were formed by stationary and seawards (southwards) migrating bars during storms (Clifton et al. 1971; Davis \& Fox 1972; Clifton 1976; Hunter et al. 1979). Some shoreface deposits represent preserved shore-parallel bars, with wave-ripple cross-lamination and cross-bedding, and runnels with wave-ripple laminated fill, interpreted as fair-weather deposits (Figs 12-15).

The conglomerate lenses and the low-angle inclined laminated beds of barred upper shorefaces are interpreted as bar and swash-/surf-zone deposits (Clifton 
Current-ripple orientations in middle shoreface deposits, localities 10 and 11

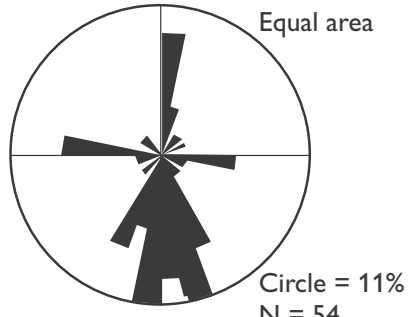

$\mathrm{N}=54$

Current-ripple orientations in sand sheet deposits, localities 7, 8, 10,11

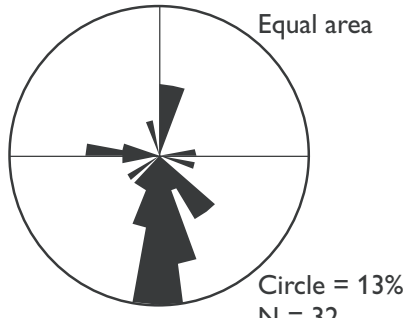

$\mathrm{N}=32$
Wave-ripple crestline orientations in middle shoreface deposits, locality 11

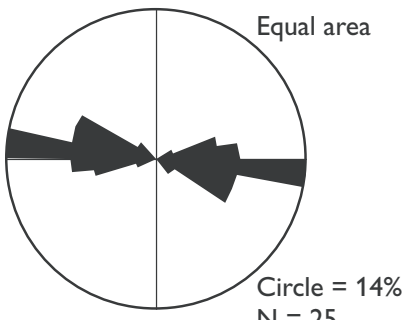

Wave-ripple crestline orientations in shallow offshore sand sheet deposits, localities $7,8,10,11$

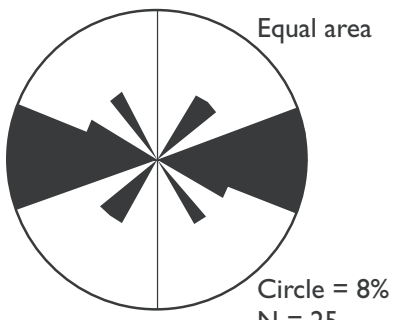

Current-ripple orientations in upper shoreface deposits, localities 6, 6A, 7, 9, 9A, 10,11,14

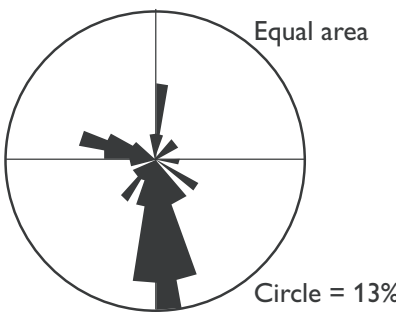

$\mathrm{N}=47$
Wave-ripple crestline orientations in upper shoreface deposits, localities 6, 6A, 7, 9, 9A, 10,11, 14

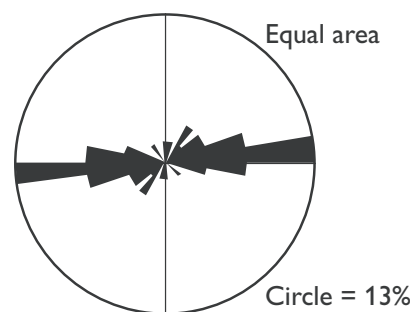

$\mathrm{N}=28$

Fig. 16. Current-ripple foreset azimuths and wave-ripple crestline orientations in shoreface and shallow offshore sandstones. Data from several localities are included. The shoreface and shallow offshore units were most likely deposited by, or in connection with, progradation of roughly east-west-oriented shorelines. Each shoreface unit prograded from the north. This type of data does not allow precise interpretation of the shoreline orientation, due to possible wave and current interference patterns in the nearshore areas. The data may, however, indicate a general trend, as they show a pronounced lateral persistence.

The seawards inclination of the master bedding in 1969, 1976; Hunter et al. 1979). The presence of conglomerates indicates proximity to a fluvial source, and they are interpreted to have been deposited in wavereworked fluvial mouth bars and adjacent beaches. The sediments are thought to have been delivered to the shoreface regions through braided fluvial channels, which must have been shallow, because no channel deposits survived subsequent transgressive marine erosion. some upper shoreface sandstones is interpreted to indicate that shoreface progradation occurred during high energy conditions with high sediment influx (Cant 1991; Swift \& Thorne 1991). The master bedding marks an abrupt upwards change from lower to middle shoreface aggradation to dominantly upper shoreface progradation. The erosional surface which in many cases separates middle or lower from upper shoreface deposits

Fig. 17. A fine pebble lag, $1 \mathrm{~m}$ thick, bounded below by a marine surface of erosion (MSE) and topped by a flooding surface (FS). The lag apparently forms a single cross-bed with foresets dipping up to $20^{\circ}$ towards the south, indicated by the fracture pattern. The formation of the lower boundary (MSE) was followed by colonisation of Diplocraterion habichi and Monocraterion tentaculatum during an early stage of water deepening (arrow 1). During the subsequent winnowing and deposition of coarse material, the burrowing organisms still inhabited the sediment (arrow 2). The deposits become increasingly bioturbated upwards with nearly 100\% burrowing at the top, and D. habichi descending from the top flooding surface. Pelion Formation, locality 7 (Fig. 2).

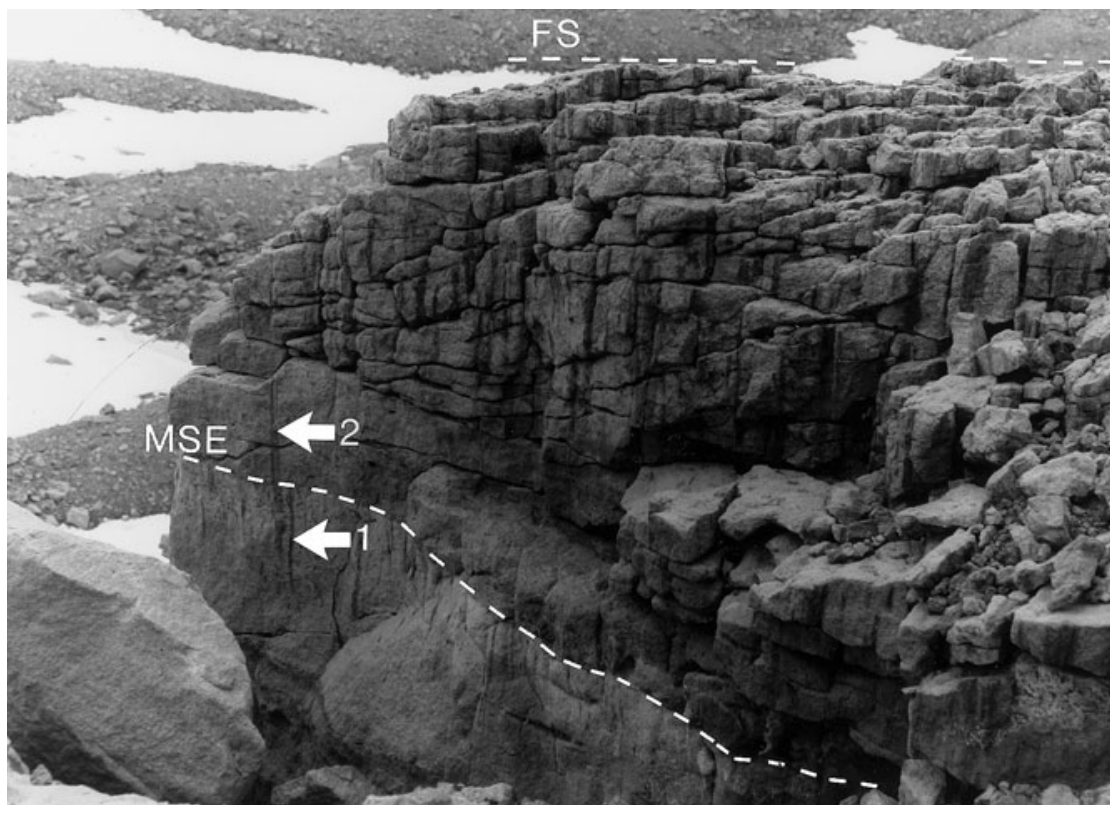



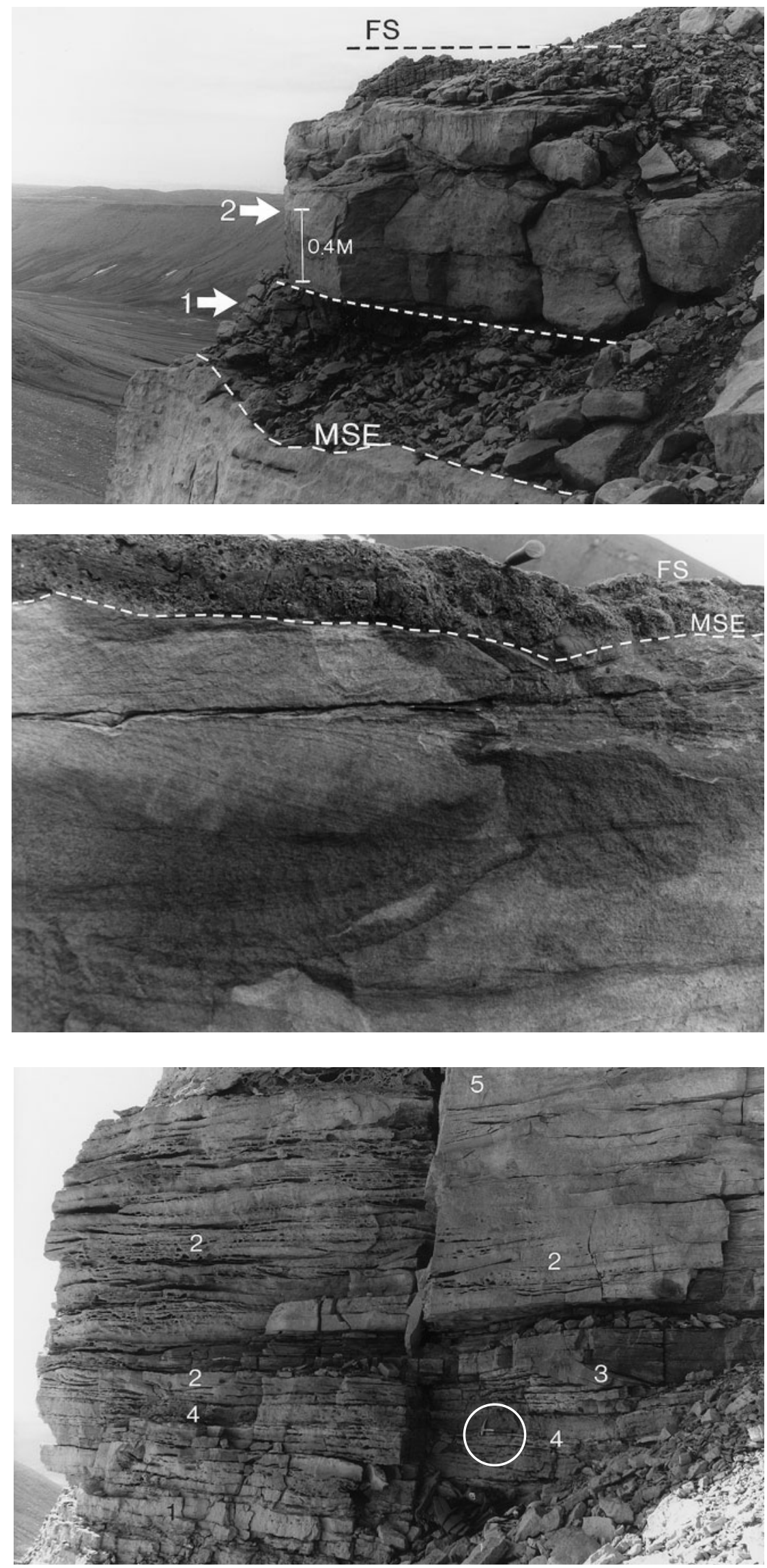

Fig. 18. Non-winnowed deposits, interpreted to have formed during transgressive deepening. They overlie a marine surface of erosion (MSE), and consist of massive or weakly laminated silty, fine-grained sandstones (arrow 1) overlain by coarse-grained, even, parallel bedded and cross-bedded sandstones

(arrow 2). Bioturbation by Diplocraterion habichi and Monocraterion tentaculatum is concentrated in the uppermost part, descending from the top flooding surface (FS). The coarse grain size of the upper bed suggests that it was deposited as a shoreface-connected sand-sheet during shoreface retreat. Pelion Formation, locality 7 (Fig. 2)

Fig. 19. Carbonate-cemented pebble lag (uppermost), interpreted to have formed during transgressive erosion. The lag overlies upper shoreface to foreshore, cross-bedded sandstones with an erosional base, representing a marine surface of erosion (MSE, dashed line). The upper boundary is a marine flooding surface (FS), which is overlain by laminated, offshore siltstones. The conglomerate bed can be traced laterally over an area of $4 \times 2 \mathrm{~km}$. Hammer shaft for scale, $4 \mathrm{~cm}$ across end. Pelion Formation, locality 10 (Fig. 2).

Fig. 20. Sandstones showing horizontal to low-angle inclined beds (1), overlain by swaley cross-stratified beds (2), cut by S-SE-oriented rip-channel trough fills (3). Wave-ripple cross-laminated beds occur at different levels (4). Parallel-laminated surf-zone beds are also present (5). The sandstones are interpreted as wavedominated shoreface deposits. Hammer head (encircled) is $18 \mathrm{~cm}$ long. Pelion Formation, locality 7 (Fig. 2). 
was formed by storm-wave and current scour in front of the prograding upper shoreface. The surface is diachronous, and it has no regional significance in correlation (Nummedal \& Swift 1987; Swift et al. 1991). The southwards orientation of the inclined upper shoreface master bedding and the dominant east-west orientation of wave-ripple crests in both lower and upper shoreface deposits indicate that shorelines prograded southwards (Fig. 16). The overall grain-size gradients suggest sediment influx from the north-west.

Non-barred, wave-dominated upper shoreface sandstones were deposited in some areas, especially at localities 6, 6A, and 7 (Fig. 20). The sandstones are generally medium-grained, well sorted, and dominated by swaley and wave-ripple cross-laminated beds, erosionally cut by north-south oriented rip-channels and gutter casts (facies 9). The deposits always gradationally overlie fine- to medium-grained, low-angle inclined and horizontally-bedded sandstones of facies 8 (Fig. 20). The deposits are capped by a marine surface of erosion, overlain by erosionally-based swaley cross-beds. The degree of bioturbation is generally low, and Planolites vulgaris and Skolithos isp. have been identified. Belemnites occur scattered throughout the facies.

The dominance of swaley cross-bedding and waveripple cross-lamination, erosionally cut by rip-channels and gutter casts, suggests deposition in a storm-wave dominated upper shoreface (Plint 1988; Bhattacharya \& Walker 1991). The fossil assemblage indicates marine conditions. The good sorting suggests a position well away from fluvial input sources. The predominant north-south orientation of gutter casts and rip-channels suggests an east-west oriented shoreline. The generally low degree of bioturbation may reflect the non-barred character of the shoreline, lacking protected areas.

\section{Middle shoreface}

The middle shoreface deposits consist of 1-10 m of fine- to locally coarse-grained sandstones (facies 7,8 ), containing scattered bivalves and belemnites. Waveformed ripples and mega-ripples characterise most of the deposits, including lenses of cross-bedded, mediumto coarse-grained sandstones, and erosionally-based fine- to coarse-grained, laterally aggradational trough fill sandstones, up to $0.5 \mathrm{~m}$ thick (facies 7). Bioturbation is generally very intense. Horizontal traces dominate in the wave-rippled beds, and dominant trace fossils are: Taenidium serpentinum, Gyrochorte comosa, Planolites isp., Phycodes isp., and Thalassinoides suevica, whereas vertical traces dominate in the cross-beds, including notably Monocraterion tentaculatum, and Skolithos linearis. The trace fossils are referred to the Planolites, Curvolithus and Diplocraterion habichi ichnocoenoses of Heinberg \& Birkelund (1984). The deposits may form bedsets, up to $8 \mathrm{~m}$ thick, of fine- to medium-grained, low-angle inclined to flat-bedded sandstones, interbedded with wave-rippled beds and overlain by swaley cross-bedded sandstones of the upper shoreface (facies 8; Figs 10, 20). Palaeocurrent directions are towards the west, through south to the east, but south to southeast orientations dominate (Fig. 16). The lower boundary of the deposits is erosional and wavy, or there is a gradual upwards change from hummocky cross-stratified or even, parallel-laminated beds, and the boundary is placed at the base of the wave-ripple laminated beds. The deposits may directly overlie marine lags without any intervening offshore or lower shoreface sediments. The upper boundary of middle shoreface deposits is in most cases erosional and sharp, showing a relief of up to $0.4 \mathrm{~m}$, or there may be a textural and structural gradational change into upper shoreface deposits, showing both horizontal traces, and vertical traces.

The dominant fine- to medium-grained, ripple-laminated beds were deposited under the influence of fairweather waves. The dominance of horizontal traces indicates overall slow deposition, whereas the change to vertical traces represents a seawards translated upper shoreface fauna (Dörjes \& Hertweck 1975; Frey 1975; Ekdale et al. 1984; Pemberton \& Frey 1985). Fair-weather deposition was punctuated by storm erosion, reworking and deposition, represented by the medium- to coarse-grained, cross-bedded lenses. The cross-beds are interpreted to have been deposited in rip-channels, on rip-channel mouth-bars and as mega-ripples, formed during seawards transport of sediments during major storms. The current orientations obtained from the ripchannel and associated mouth-bar deposits, and waveripple crestline orientations suggest an east-west orientation of the coastline (Fig. 16). The large spectrum of preserved wave- and current-formed sedimentary structures suggests that deposition was influenced both by storm and fair-weather wave processes, and that the water depth was in the range of 5-15 $\mathrm{m}$ during deposition. Similar deposits have been described by Clifton (1976), Hunter et al. (1979), Dabrio \& Polo (1981), and Swift et al. (1991).

The flat-bedded sandstones are interpreted as sand sheets deposited from density currents, fed by laterally 
extensive erosion of upper shoreface deposits during storms. This process has been well described by Howard \& Nelson (1982) and Nelson (1982). The flat-bedded sandstones may also have formed rip-channel mouth bars, deposited from a mixture of bedload and suspension fall-out, as indicated by the associated ripchannel fills which occur locally. Channelised and non-channelised sediment transport probably took place simultaneously during storms; this is indicated by the small size of the preserved rip-channels, compared to the thickness and lateral extent of the flat-bedded sandstones (Fig. 20).

Shoreface associations may lack lower shoreface and offshore transition zone deposits, and consist of middle shoreface deposits in the lower part, overlying lags or marine regressive surfaces of erosion (as shown in Figs 8, 9). This is thought to indicate that the shoreface prograded into very shallow water, as described for Cretaceous deposits of the US Western Interior Seaway by Hart \& Plint (1993).

\section{Lower shoreface to offshore transition zone}

The lower shoreface to offshore transition zone deposits are characterised by a backstepping, aggradational to forestepping facies stacking pattern. The deposits have a basal lag, ranging from a layer only one pebble thick up to $1 \mathrm{~m}$ thick (facies 1,2 ), or rest directly on a strongly burrowed marine erosion surface, locally overlain by less than $2 \mathrm{~m}$ of fine- to medium-grained, structureless, faintly-laminated or cross-bedded sandstone (facies 3;
Figs 17-19). The basal deposits are overlain by less than $0.5 \mathrm{~m}$ of strongly burrowed calcareous siltstone or laminated siltstone (facies 5; Figs 11, 21), locally rich in bivalves, belemnites and ammonites, sharply overlain by laminated, silty, fine-grained sandstone, $0.5-15 \mathrm{~m}$ thick (facies 6). The latter deposits consist of intercalated even, parallel-laminated or hummocky cross-stratified beds, or show an upwards transition from horizontally laminated to hummocky cross-stratified beds. Wave ripple-formsets locally occur in the uppermost part of the deposits. Burrows of Gyrochorte comosa, Taenidium serpentinum, Planolites vulgaris and Helminthopsis magna (Planolites ichnocoenosis) are restricted to the even, parallel laminated beds. Marine body fossils are found locally throughout. The association is capped by a sharp, wavy boundary, or shows a gradational contact to overlying fine- to coarse-grained pebbly, rippled or cross-bedded sandstones of the middle or upper shoreface (Figs 8-11).

The association was deposited in the lower shoreface to offshore transition zone. The coarse-grained basal lags and overlying calcareous deposits are interpreted as having been formed during and after transgressive erosion of the underlying shoreface deposits, and indicate an increase in water depth from above fair-weather wave base to near or below storm wave base (Nummedal \& Swift 1987; Nummedal et al. 1993; Swift et al. 1991). The lags were formed during a time of winnowing or erosion with no net deposition, and the overlying condensed facies (facies 5, 6) were deposited slowly from suspension fall-out, occasionally influenced by weak currents. The hummocky cross-stratified beds

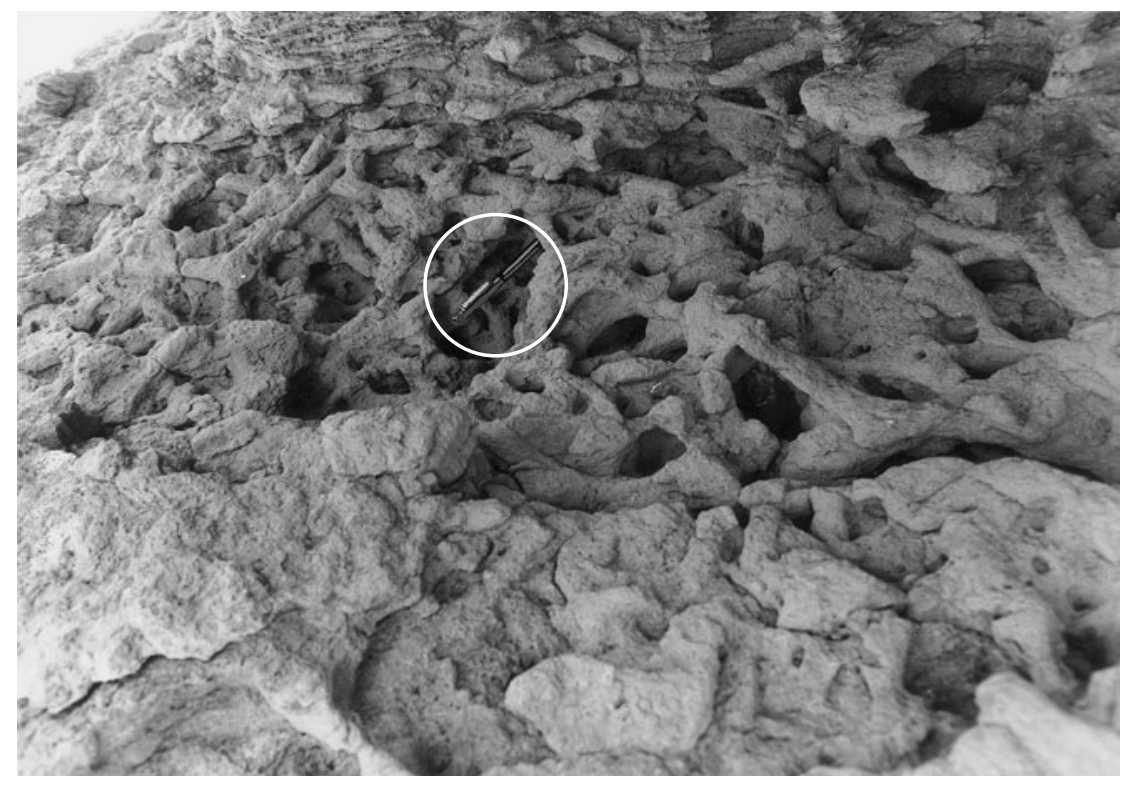

Fig. 21. A calcareous siltstone bed with a Thalassinoides suevica polygonal network (seen from below). The bed is $0.3 \mathrm{~m}$ thick; it is interpreted as representing a firmground, developed during a time interval of reduced deposition, during a rise in relative sea level (cf. Bromley 1975). Pen (encircled) is $14 \mathrm{~cm}$ long. Pelion Formation, locality 11 (Fig. 2). 
were formed by storm wave-oscillation, and individual beds represent single storm events (Harms 1975; Brenchley et al. 1986, 1993). Deposition took place at a minimum water depth of 5-15 $\mathrm{m}$, interpreted from the thickness of the overlying middle and upper shoreface deposits, and the preserved bedforms and trace fossils. The marine trace fossils of the horizontally laminated beds are typical of an environment dominated by slow suspension fall-out (Seilacher 1967; Frey 1975; Heinberg \& Birkelund 1984).

\section{B. Estuarine association}

Preserved estuarine deposits are rare, and have only been found at two localities. They are described below and include channel and shoal deposits.

\section{Estuarine channel}

Estuarine deposits are exposed in the valley between the mountains of Pelion and Parnas, where estuarine deposits of the Pelion Formation erosionally overlie the Sortehat Formation (Fig. 2, locality 10; see also Figs 22, 23). Erosional incision reaches a presumed maximum of $30-40 \mathrm{~m}$ in the central part of the exposure, which is $1.5 \mathrm{~km}$ long and is oriented approximately east-west, perpendicular to the axis of the incised valley, as deduced from current orientations and large-scale bed geometries. The estuarine deposits are 30-40 m thick and are dominated by medium-grained sandstones with a few conglomerate beds (facies 9). Two channel sandstone bodies occur, separated by thin spit deposits. The upper estuarine channel unit is overlain by strongly burrowed offshore sandstones and siltstones of facies 6 and 7 (Fig. 22).

The basal erosion surface is draped by a discontinuous, allochthonous, vitrinite coal layer, up to $4 \mathrm{~cm}$ thick, overlain by a fine-grained sandstone, up to $0.5 \mathrm{~m}$ thick, rich in coal debris and mica (Fig. 23). The over-

Fig. 22. Estuarine channel association (B). The inclined master bedding of the lower channel unit is indicated $(3.5-29 \mathrm{~m})$. The lower channel unit is capped by spit sandstones (29-32.5 m), which are overlain by the upper channel unit (32.5-41 m). Bioturbated, fully marine offshore sandstones occur on top of the upper channel-fill. Asterisk indicates inferred floodplain deposits. Pelion Formation, locality 10 (Fig. 2). For legend, see p. 823 .

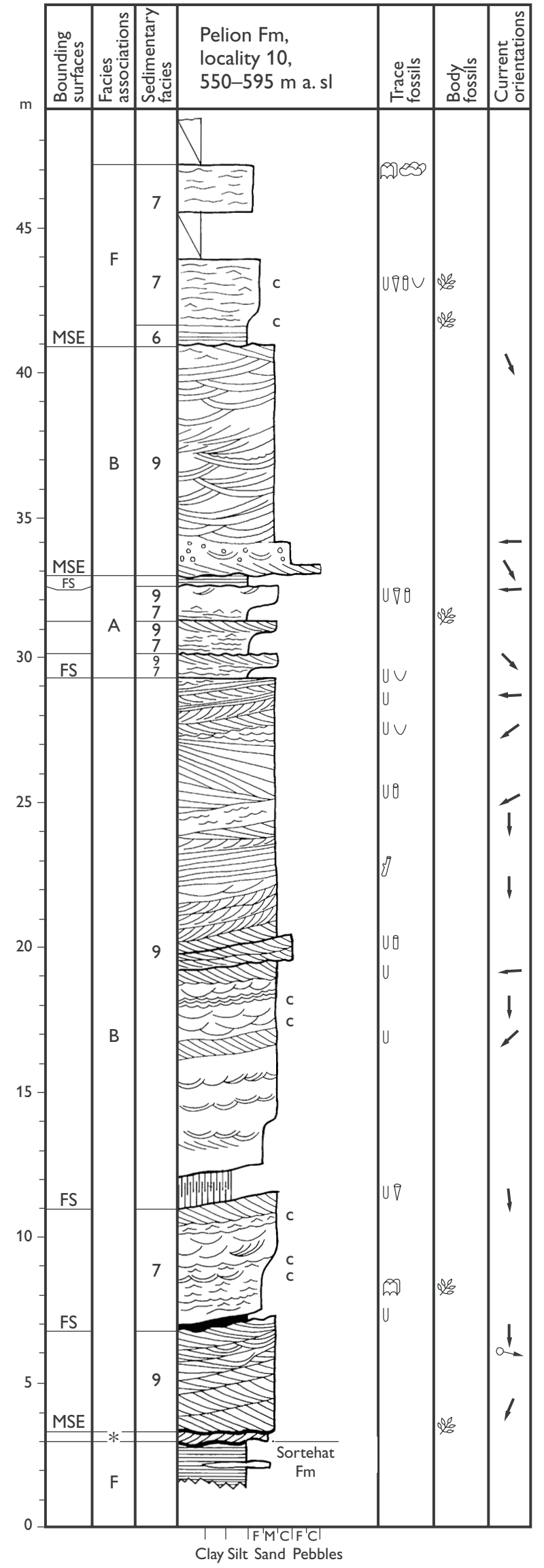


lying sandstones are characterised by low-angle master bedding, dipping $c .4^{\circ}$ towards the east, representing the fill of a major, laterally migrating estuarine channel (Morton \& McGowen 1980; Cotter 1983; Yang \& Nio 1989; Sha \& de Boer 1991). The general current orientation was towards the south, but other directions are also observed. Large-scale cross-beds, up to $2 \mathrm{~m}$ thick, dominate, showing planar and tangential foresets dipping towards the south. The concentration of organic debris is commonly high along bottomsets, and may form allochthonous coal beds up to a few centimetres thick. Petrified wood fragments are abundant throughout. Skolithos linearis and Diplocraterion habichi occur at eight levels from $4 \mathrm{~m}$ above the base of the deposits and upwards. The cross-beds may be separated by cross-laminated sandstone beds or bedsets $0.2-3 \mathrm{~m}$ thick, locally containing coal debris and centimetrescale, discoidal quartz pebbles. Ripple crests are generally oriented east-west.

The lower channel unit is overlain by three coarsening-upwards units, each $c .1 \mathrm{~m}$ thick, with a horizontally bedded or cross-laminated lower part and a planar or trough cross-bedded upper part (Fig. 22). The top unit is erosionally overlain by the upper channel fill unit, which is up to $10 \mathrm{~m}$ thick, consisting of fairly well sorted, medium-grained sandstones, except for the lowermost metre, which is coarse-grained. The channel fill shows 1-20 $\mathrm{m}$ wide troughs, which cut into each other, with margins typically inclined less than $10^{\circ}$. The trough fills show concordant bedding and lamination, and occasionally wave-rippled surfaces, but lateral accretion surfaces also occur. Palaeocurrent orientations are consistently towards the south. The channel deposits are overlain by an erosionally-based sandstone unit, $3 \mathrm{~m}$ thick, rich in coal debris, larger fragments of plants, and petrified wood. The sandstones show wave-ripple cross-lamination, and locally wave-ripple formsets. This upper unit shows moderate to very strong burrowing, including Diplocraterion habichi, Monocraterion tentaculatum, Skolithos linearis and Teichichnus isp.

The succession is interpreted as the fill of a minor incised valley, cut into the dark offshore mudstones of the Sortehat Formation by fluvial erosion during a time of sea-level lowstand. The vitrinite coal layers and finegrained sandstones rich in coal debris of the basal valley-fill deposits are interpreted as the erosional remains of floodplain sediments, which escaped transgressive erosion during the transformation of the river mouth into an estuary.

The large-scale cross-beds of the lower estuarine channel unit were formed by migration of sub-channels and bars on the inclined accretion surface of the channel margin. The channel sandstones are interpreted as freshwater-influenced ebb-tidal deposits, based on the large amount of plant material, the dominance of southwards migrating bed-forms, and the restriction of marine trace fossils to channel inactivity surfaces (Barwis 1985; Yang \& Nio 1989; Allen 1991). The fine-grained wave-rippled beds and bedsets rich in coal debris and with scattered discoidal pebbles that occur at different levels on the inclined master bedding surface, were possibly formed by wave reworking during channel inactivity. The predominant east-west orientation of wave-ripple crests is interpreted to reflect the north-south

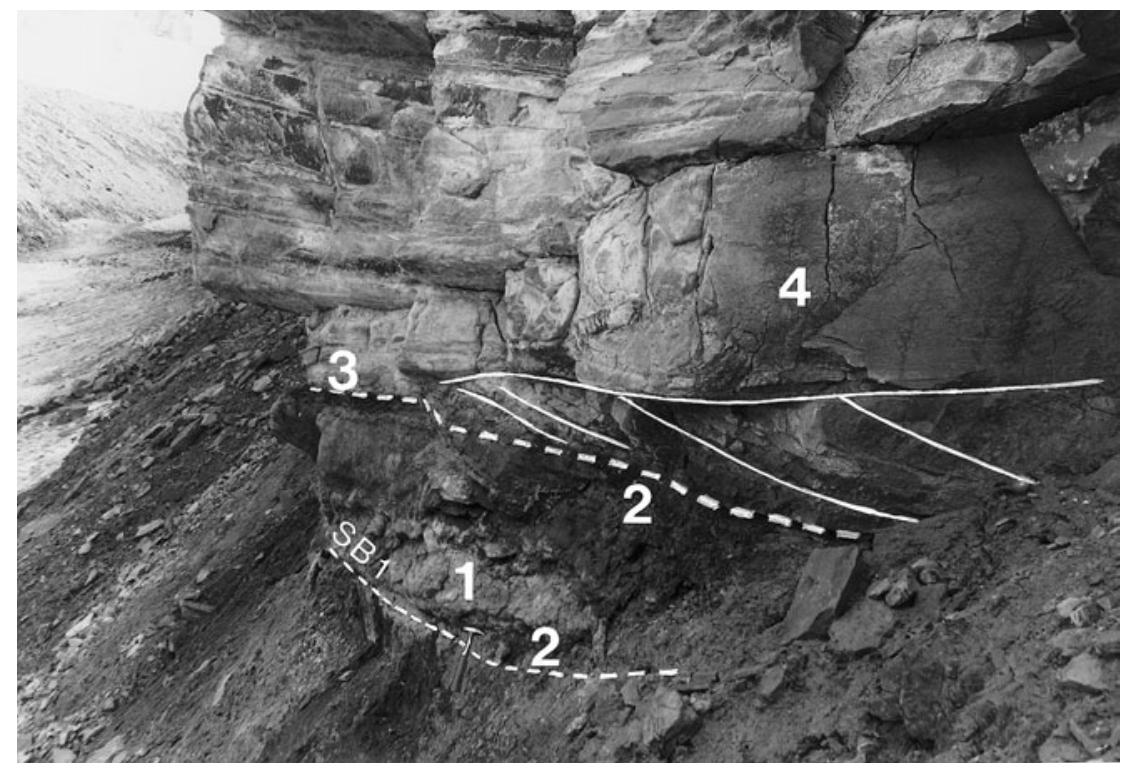

Fig. 23. Basal $4 \mathrm{~m}$ of the estuarine channel sandstones, filling a minor valley incised into the Sortehat Formation. The deposits belong to sequence P1 (Fig. 6). SB1, lower sequence boundary of the Pelion Formation, separating estuarine deposits from underlying marine silty shales of the Sortehat Formation; $\mathbf{1}$, floodplain deposits, representing the oldest deposits in the incised river valley; $\mathbf{2}$, allochthonous vitrinite and durite coal layer; $\mathbf{3}$, base of lower estuarine channel unit (dotted line); $\mathbf{4}$, Estuarine channel sandstones. Hammer for scale (at SB1). Pelion Formation, locality 10 (Fig. 2). View is towards the south-west. 
orientation of the estuary. The three small-scale coarsening-upwards units, overlying the estuarine tidal channel deposits are interpreted as spit deposits. They were formed by laterally migrating spits, which filled the accommodation space left above the channel fill after the active channel had moved laterally by erosion and accretion (Terwindt 1971; Yang \& Nio 1989; Allen 1991).

The upper channel unit is also interpreted as a freshwater-influenced ebb-tidal estuarine channel fill, based on the invariably southwards-oriented, erosionallybased large to giant-scale foresets, and the lack of marine fossils and trace fossils (Dalrymple et al. 1992). The amalgamated character of the channel deposits indicates a high sediment influx to the estuary, larger than the rate of creation of new accommodation space. The uppermost $3 \mathrm{~m}$ of burrowed, wavy bedded sandstones are interpreted as a sand sheet, deposited during marine flooding of the estuary (Campbell \& Oaks 1973; Dalrymple et al. 1992).

\section{Estuarine shoal}

Estuarine shoal deposits are exposed low on the south slope of the Olympen mountain (Fig. 2, locality 8). The exposed part of the unit is $14 \mathrm{~m}$ thick and consists of fine- to medium-grained sandstones, with a few conglomeratic sheets and lenses, each less than $10 \mathrm{~cm}$ thick. Clay and coaly detritus form thin drapes and layers. The deposits overlie and are overlain by shallow offshore sediments; the lower boundary is only exposed at a single place, where it is overlain by bottomsets of a planar cross-bed, showing bundled, low-angle foresets, rich in coal debris. The sedimentary structures are dominated by large-scale trough and planar cross-bedding, low-angle trough cross-bedding, wavy bedding, and planar-bedding (facies 7, 9). Beds are generally less than $0.5 \mathrm{~m}$ thick.

In the lowermost part of the unit, individual crossbeds can be traced in a southwards, down-current direction for more than $80 \mathrm{~m}$ without significant variation in thickness. They show bundle-wise up-building of sigmoidal, tangential or angular foresets, which may be draped by coaly debris and dark clay. They are separated by wavy bedded, fine-grained sandstones. The middle part of the unit is dominated by interbedded low-angle, cross-bedded sandstone with shallow crossbedded sandstone trough fills, up to $1 \mathrm{~m}$ wide, with foresets draped by coal debris, and swaley cross-stratification. Cross-beds show foreset azimuths from $90^{\circ}$ through $180^{\circ}$ to $220^{\circ}$. Bed boundaries of the lower and middle part of the unit mostly have a wavy appearance, and can in most cases be followed throughout the exposure. The upper part is dominated by non-bioturbated, swaley cross-stratified sandstones. Ophiomorpha nodosa burrows occur in the lower and middle part of the unit, where they descend in great numbers from bedding planes.

The estuarine shoal interpretation is based on the internal sedimentary structures and the stratigraphic position, sandwiched between offshore sandstones and siltstones. The presence of sandstones rich in coal debris, coal layers at the base of troughs, small-scale waveformed ripples, and the dominance of Ophiomorpha nodosa indicate deposition at very shallow water depths, not far from a terrestrial source (Clifton 1976, 1983; Barwis 1985; Curran 1985; Pollard et al. 1993). The basal estuarine shoal beds with bundled foresets, are interpreted to have formed by migration of sub- to intertidal sand waves, under the influence of neap-spring fluctuations of tidal currents. The wave-rippled beds are interpreted as slack-water sediments. These lower deposits are interpreted to have accumulated in shallow tidal channels, probably less than a few metres deep, based on the thickness of the channel fills. The middle part of the estuarine shoal deposits strongly resembles modern tidal shoal sediments (de Raaf \& Boersma 1971; Terwindt 1971; Reineck 1972; Boersma $\&$ Terwindt 1981). The non-bioturbated upper part of the deposits is interpreted to reflect a general increase in marine storm and wave influence. The vertical facies development of the estuarine shoal deposits closely resembles tidal flat associations from the Lower Cretaceous Fall River Formation, Wyoming (Campbell \& Oaks 1973) and modern examples (de Raaf \& Boersma 1971; Clifton 1983; Terwindt 1988). The estuarine shoal deposits are thought to represent non-erosional drowning of an estuarine shoal area (Campbell \& Oaks 1973; Dalrymple et al. 1992). The top marine surface of erosion is interpreted to have formed during the final marine transgression of the estuary.

\section{Tidal inlet association}

Tidal inlet deposits are exposed at two stratigraphic levels at Trefjord Bjerg in the easternmost part of the exposure belt (Fig. 2, localities 6, 6A, 7). The lower and upper inlet units are $20-25 \mathrm{~m}$ and $20-35 \mathrm{~m}$ thick, respectively. Both units can be traced laterally east-west for $1.5 \mathrm{~km}$. The lower can be followed north-south for $600 \mathrm{~m}$, and the upper for several kilometres, without 


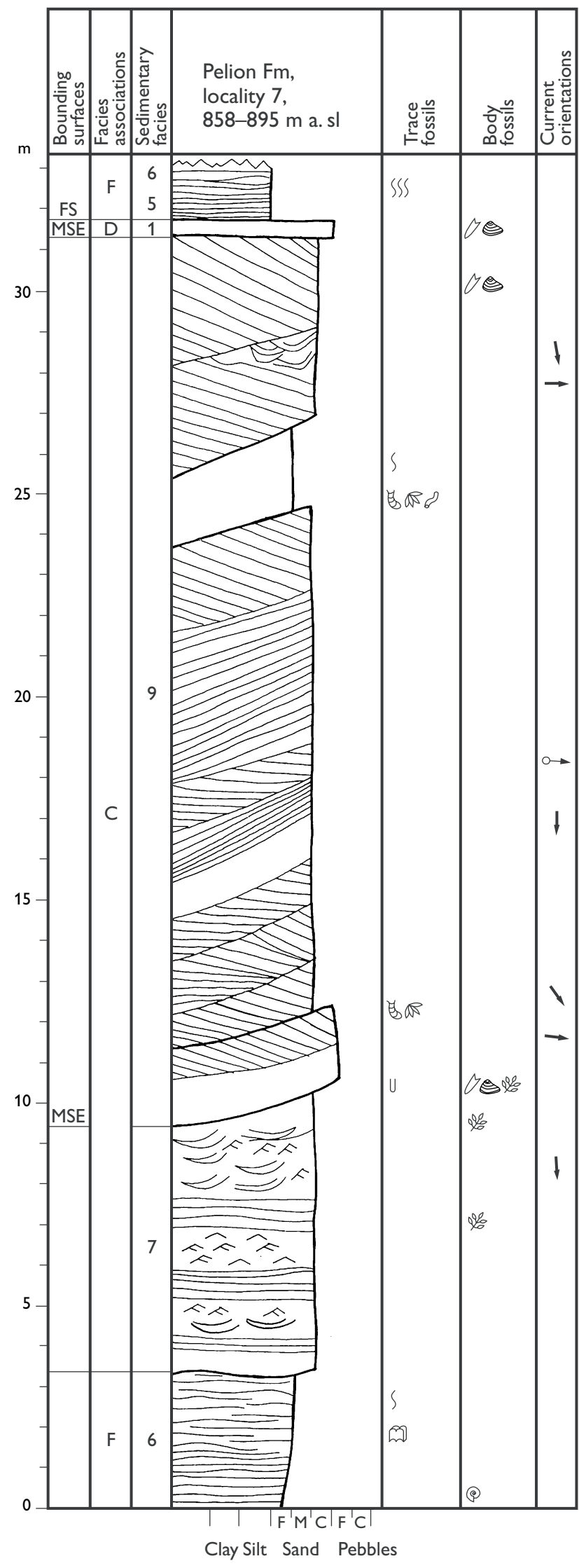

any change in facies pattern. Locally, mouth-bar deposits are present in the lower part of the association. In the absence of basal mouth-bar deposits, the tidal inlet units erosionally overlie offshore siltstones and sandstones.

The mouth-bar deposits are up to $8 \mathrm{~m}$ thick, and consist of fine- to medium-grained current- and wave-ripple cross-laminated sandstones (facies 7). The upper part of the mouth-bar deposits is especially rich in coal debris, plant fragments, bivalves and belemnites. The mouth-bar deposits are erosionally truncated by the base of the tidal inlet channel fill, and locally a large number of Diplocraterion habichi burrows descend from the erosion surface. The inlet channel fill consists of medium- to coarse-grained, generally well-sorted sandstones (facies 9), with very subordinate conglomerates. Vertical trends in grain size have not been recorded (Figs 24, 25). The master bedding of the tidal inlet sandstones is inclined $4^{\circ}$ in an easterly direction. The master bedding surfaces show tangential to angular lower bedding contacts and are erosionally truncated updip by a marine erosion surface. The inclined strata are $0.2-2 \mathrm{~m}$ thick and show planar and trough cross-bedding, massive bedding or ripple cross-lamination. Wave-ripples may occur at bed boundaries. Reactivation surfaces are common, both at bed and master bedding scale. Herringbone cross-bedding is common. Southerly palaeocurrent directions dominate with subordinate northerly directions, perpendicular, or at a very high angle, to the dip direction of the master bedding surfaces. Scattered Diplocraterion parallelum, Planolites isp., Phycodes isp. and a single Taenidium serpentinum were observed in the channel deposits. Diplocraterion habichi and Monocraterion tentaculatum descend in large numbers from the marine erosion surface at the top of the inlet channel sandstones. Ammonites occur in the lower part of the association, whereas belemnites and bivalves are found scattered in the upper part.

Fig. 24. Tidal inlet association (C), consisting of large-scale planar cross-bedded, medium- to coarse-grained sandstones (10-31 m), erosionally overlying finer grained, cross-laminated, and cross-bedded inlet mouth deposits $(3.5-10 \mathrm{~m})$. The largescale bedforms in the inlet deposits indicate that powerful currents were active at the time of deposition. Bedforms mainly migrated towards the south, perpendicular to the azimuth of the master bedding planes. Ammonites found in the offshore deposits below the inlet channel (at $0.5 \mathrm{~m}$ ) belong to the Cranocephalites borealis $\beta$ faunal horizon. Pelion Formation, locality 7 (Fig. 2). For legend, see p. 823. 
Fig. 25. Upper tidal inlet association (C) from the lower part of the section in Fig. 24. The master bedding (MB, dashed) forms giant-scale foresets or clinoforms, internally showing parallel bedding (1), large-scale planar cross-bedding (2), and homogeneous, structureless bedding (3). 4, wave-ripple cross-bedding. Person for scale $(170 \mathrm{~cm})$. Pelion Formation, locality 7 (Fig. 2).

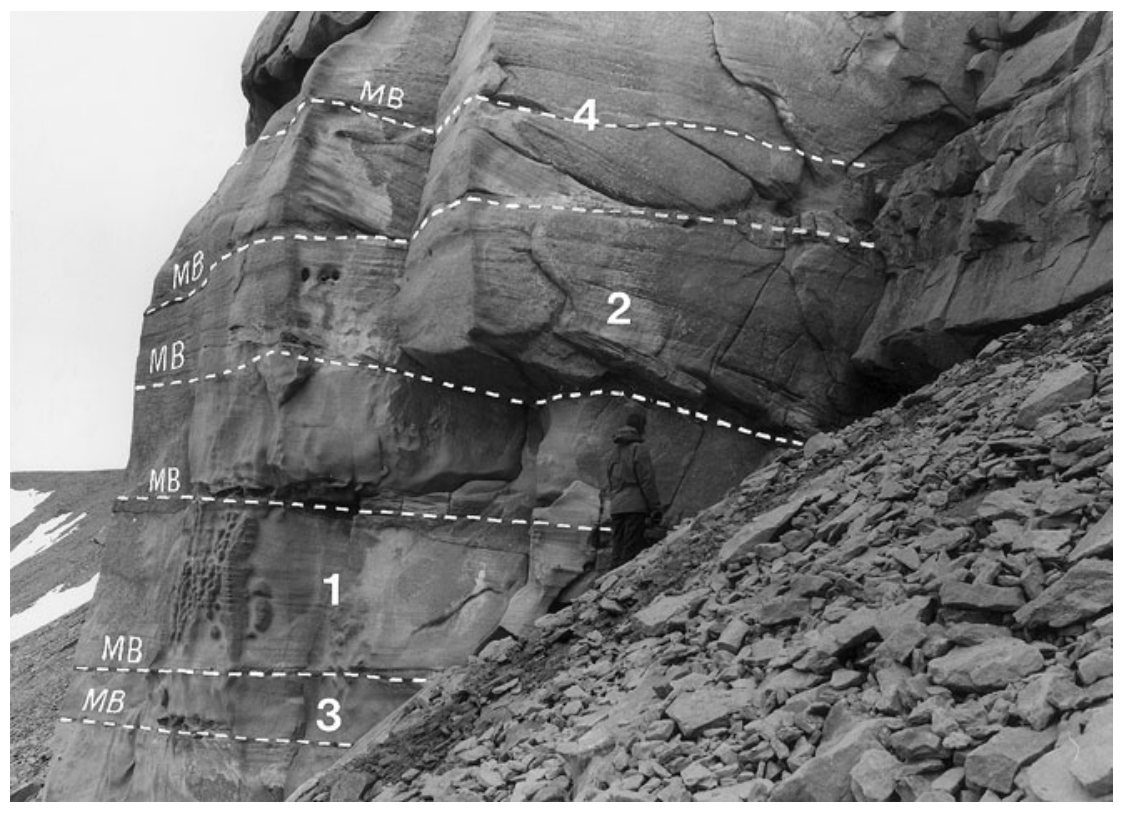

The body and trace fossils indicate that normal marine salinities prevailed, at least periodically. The restriction of trace fossils to distinct levels suggests that rates of deposition and erosion of the active depositional surfaces were generally too high for colonisation, which only occurred during longer periods of bedform stillstand.

The tidal inlet interpretation is based on the lateral association with shoreface deposits, and by the internal sedimentary structures, including the inclined master bedding (Terwindt 1971, 1981; Nio \& Yang 1991). The eastwards inclined master bedding reflects lateral migration of the inlet, and the presence of up to $2 \mathrm{~m}$ thick cross-beds suggests deposition from powerful tidal currents. The common occurrence of herringbone cross-bedding suggests that both ebb- and flood-currents operated in the channels, although ebb-oriented currents dominated, as deduced from the dominant offshore, southwards palaeocurrent direction. The generally well-sorted nature of the deposits suggests that sorting processes operated so as to maintain a uniform grain size in the channels; finer grained sediment bypassed the channels to be deposited in adjacent shoreface, channel-mouth, and offshore environments. The sediment sources for the channel fills were presumably mainly cannibalised shoreface deposits, and to a lesser extent, primary fluvial sediments. The tidal inlets were subtidal as the inclined master bedding covers the full thickness of the preserved deposits. The depositional environment was probably somewhat similar to recent tidal inlets described from the Dutch North Sea coast by Yang \& Nio (1989) and Sha \& de Boer (1991). The bases of the inlet channels form channel diastems, and are locally strongly incised. They may be considered as unconformities as discussed below in the sequence stratigraphy section. The tidal range has not been calculated due to lack of relevant data, but is estimated to have been in the range of 1-2 m, by comparison with bedform patterns of the modern North Sea. The shoreface associations of the Pelion Formation show little evidence for tidal inlets, which would have dominated if the tidal range was larger. The modern example described by Sha \& de Boer (1991) shows that at a tidal range of 1-2 $\mathrm{m}$, the tidal inlets and estuaries are the only part of the sea-facing environment that are dominated by tidal processes. Adjacent shorefaces are dominated by waves, long-shore currents and shorenormal rip-currents which are not systematically reversing. This is compatible with the data from shoreface and tidal inlet channel deposits of the Pelion Formation.

\section{Sand sheet association}

Cross-bedded sandstone sheets, 0.5-5 m thick, which are erosionally based and have sharp upper boundaries, are found in central and northern Jameson Land. They consist of fine- to coarse-grained quartzose sand- 


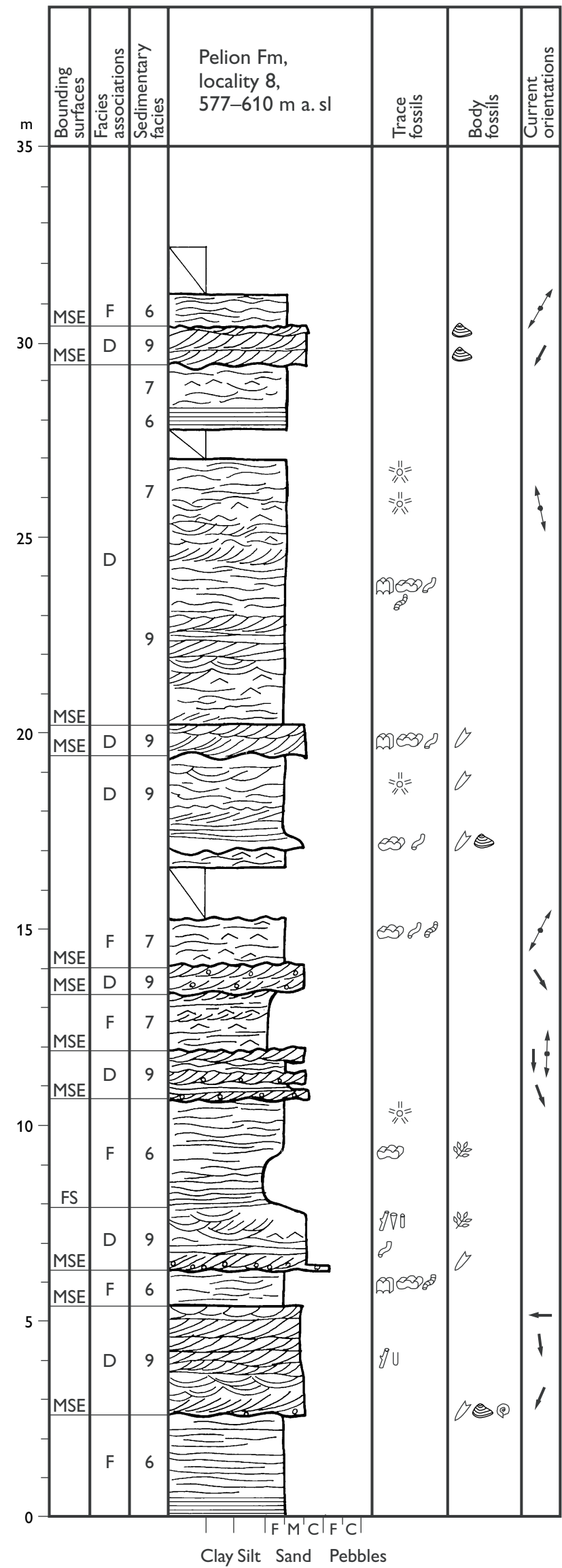

stones. The sorting is locally very good, making foresets almost invisible. Belemnites, ammonites and bivalves occur scattered. Individual sand sheets are tabular, and have in some cases been traced over more than $9 \mathrm{~km}^{2}$. The sheets may be solitary, less than $1.5 \mathrm{~m}$ thick and interbedded with shallow offshore to middle shoreface deposits, or form vertically stacked successions, in which the individual sheets are separated by thin offshore or lower shoreface units. Some thin sheets consist of a single bed with planar cross-bedding. The upper boundary is a sharp, planar surface, or is marked by well-preserved wave-formed megaripples. Sedimentary structures in the association include trough and planar cross-bedding, cross-lamination and even, parallel lamination; the structures do not occur in any clear vertical succession (Figs 9, 26). Herringbone cross-bedding, showing bundled up-building of foresets, is locally observed. Internal scour fills showing lateral accretion are present in some units, reflecting local, confined currents. A wide range of palaeocurrent directions are observed in individual sand sheets, but southwards directions predominate (Fig. 16).

The sand sheet units are generally pervasively burrowed by Taenidium serpentinum, Planolites isp. and Gyrochorte comosa representing the Curvolithos ichnocoenosis. Diplocraterion habichi, Monocraterion tentaculatum and Skolithos linearis or Ophiomorpha nodosa of the Diplocraterion habichi and Ophiomorpha ichnocoenoses commonly descend in large numbers from the upper bounding surface, but may also occur within the units. Thalassinoides suevica and Phoebichnus trochoides may also occur in large numbers. In Jameson Land, Phoebichnus trochoides has previously been described from fine-grained offshore deposits of the Fossilbjerget Formation (Bromley \& Asgaard 1972; Heinberg \& Birkelund 1984), but also occurs in Pelion Formation sandstones in Wollaston Forland (Surlyk \& Clemmensen 1983).

The body and trace fossils of the deposits indicate a fully marine environment. The sand sheet units resemble upper shoreface sandstones, but differ in many aspects (Surlyk \& Noe-Nygaard 1991). The occurrence

Fig. 26. Intercalated sand sheets (association D) and laminated transitional offshore sandstones (association F). The presence of pebbles and coarse-grained sandstone suggests that the sand sheets were closely associated with a shoreface during deposition. Pelion Formation, locality 8 (Fig. 2). For legend, see p. 823. 
of Thalassinoides suevica and Phoebichnus trochoides is a distinct feature, which only characterises sand sheet and more fine-grained offshore deposits. The close association with lower shoreface to offshore fine-grained silty sandstones is also a distinct feature of the association. The wave-formed, mega-ripple formsets at the top of the sheets were formed by storm waves during abandonment. The trace fossil distribution shows that deposition was relatively slow with minor wave-reworking, alternating with times of storm-wave and current erosion and deposition. The horizontal traces of Planolites isp., Gyrochorte comosa and Taenidium serpentinum are interpreted to have been made during slow fairweather deposition, whereas Diplocraterion habichi, Monocraterion tentaculatum, Skolithos linearis and Ophiomorpha nodosa probably represent a seawards translated upper shoreface assemblage (Dörjes \& Hertweck 1975). Phoebichnus trochoides and Thalassinoides suevica, which occur in the top of the sand sheets, were formed after abandonment, and mark the return to quiet offshore conditions, with slow deposition from suspension fall-out (Bromley \& Asgaard 1972; Surlyk \& Clemmensen 1983; Heinberg \& Birkelund 1984).

The occurrence of coarse-grained sandstone in some of the thick sand sheet units suggests a nearshore position, and some sheets pass into progradational shoreline deposits towards the north-west or north. The presence of herringbone cross-bedding probably indicates reversing tidal currents. The co-existence of smalland large-scale symmetrical and slightly asymmetrical ripples indicates that the depositional surface was influenced by both fair-weather and storm waves and currents and that deposition took place above fair-weather wave base.

\section{E. Clinoform association}

The clinoform association is only found at localities 3 and 4 (Fig. 2), where it forms the Ugleelv Member of the Pelion Formation (Surlyk 2003, this volume, fig. 5). It consists of a single tabular, clinoform bed or giantscale cross-bed, 8-35 m thick (locality 3), or two stacked beds, the lower up to $25 \mathrm{~m}$ thick and the upper up to $8 \mathrm{~m}$ thick (locality 4; Figs 27,28 ). The upper clinoform bed at locality 4 wedges out towards the south, and is not present at locality 3 (Fig. 27). The association consists of well sorted fine- to coarse-grained sandstones, with tangential clinoforms dipping up to $10^{\circ}$ towards the ESE. Systematic lateral grain-size variations are not observed. The clinoform beds have been traced over c. $50 \mathrm{~km}^{2}$. Towards the south and east, they rapidly give way to offshore siltstones and thin, fine-grained sandstones of the Fossilbjerget Formation. The association has not been traced west or north of locality 4 , due to lack of exposure. The clinoform beds have non-erosional bases, and clinoforms pass downwards into bottomsets composed of strongly burrowed, structureless or horizontally bedded fine-grained silty, carbonaceous sandstone (Fig. 29). The clinoform beds are flat-topped, bounded by a sharp erosional surface (Figs 27, 28, 30). Erosion probably removed less than a few metres of the units, as deduced from the thickness of locally preserved wave-rippled and swaley cross-bedded topset deposits. The upper decimetres of the clinoform beds are strongly carbonate cemented. Diplocraterion habichi and Monocraterion tentaculatum descend in large numbers from the upper surface, which is overlain by strongly burrowed calcareous siltstones of the Fossilbjerget Formation (facies 5).

Reactivation and inactivity surfaces are developed throughout the clinoform beds, and are reflected by two types of bundling of the clinothems. Stillstand-surfaces are overlain by downlapping low-angle clinothems and are characterised by strongly burrowed carbonaceous deposits rich in fossils and plant fragments. Firmground-type burrowing of Thalassinoides isp. and other trace fossils dominates (Fig. 31). The reactivation surfaces are characterised by erosional truncation of low-angle clinoforms by higher-angle clinoforms.

Intrasets are $0.2-1 \mathrm{~m}$ thick, mainly planar cross-beds with sharp boundaries, locally showing small-scale scours. Some clinothems consist of a cross-bedded intraset or stacked cross-laminated, cross-bedded, planar bedded, or structureless sets. The intrasets locally show bundling of foresets, a lateral development from tangential to sigmoidal foresets, single and double clay drapes of bottomsets and foresets, reactivation surfaces, and herringbone cross-stratification. Wave-eroded intraset boundaries are common. The foreset azimuths of intrasets are generally towards the south, and the intrasetforming ripples migrated perpendicular to the dip or obliquely down the ESE-dipping clinoforms.

Ammonites, belemnites and bivalves occur scattered throughout the association, and are present in large numbers on the top surface of the clinothems. Crinoid ossicles are abundant in bottomsets of the distal, wedging-out parts of the clinothems. Petrified wood fragments and carbonised plant material are common. Trace fossils include Diplocraterion habichi, Monocraterion tentaculatum, Skolithos linearis, Thalassinoides suevica, Curvolithos multiplex, Planolites vulgaris, Teichichnus 
言

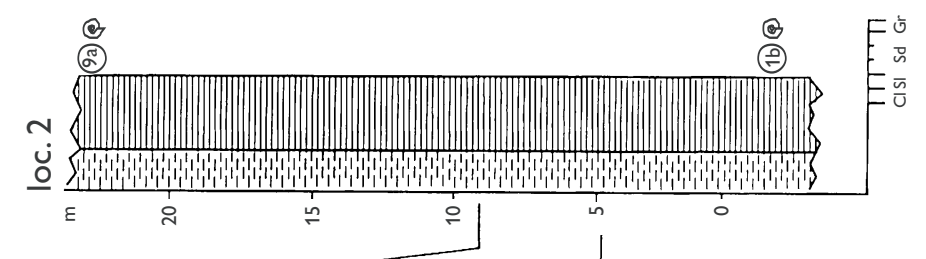

$\frac{\xi}{6}$

高

$$
\text { ? }
$$
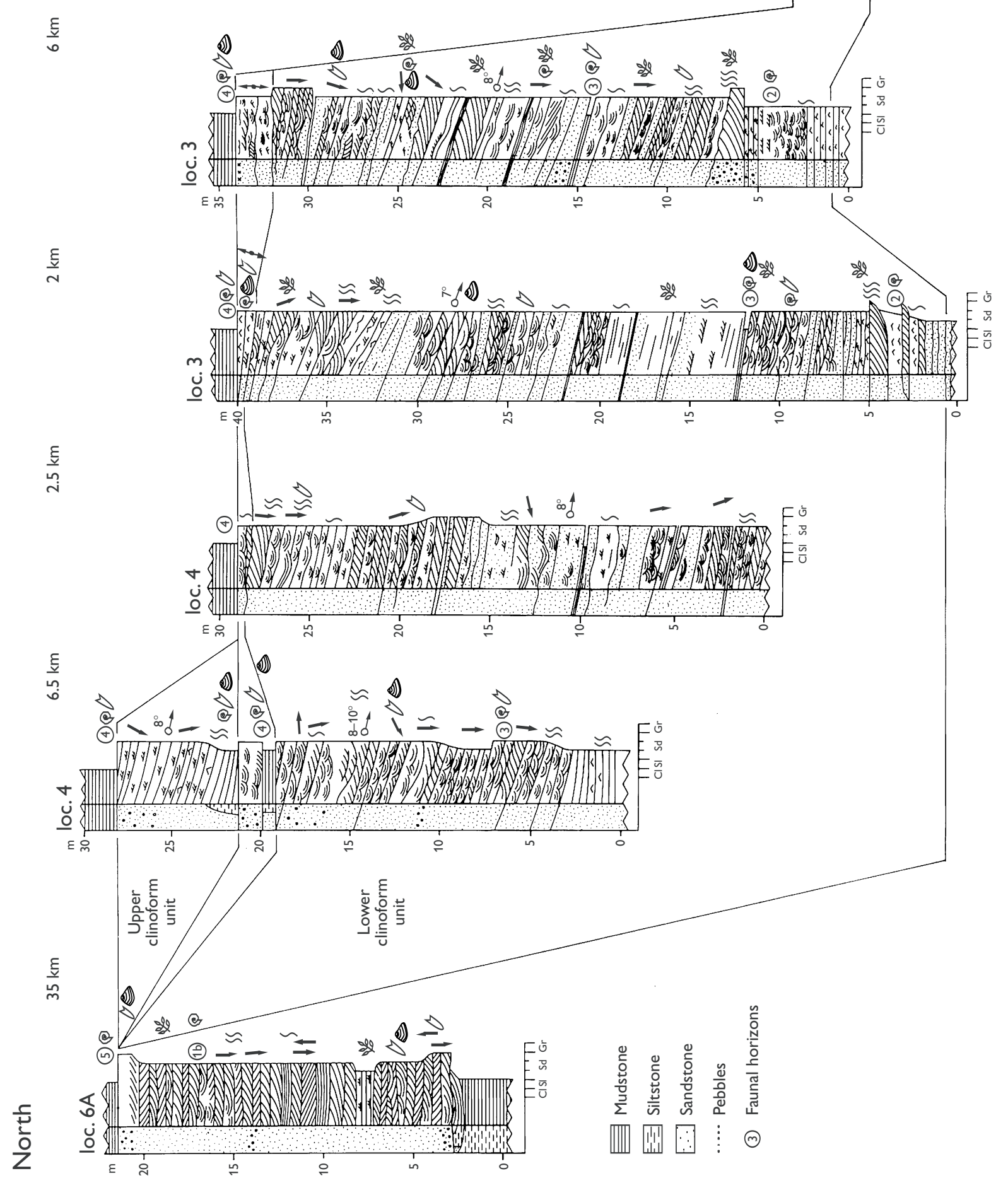


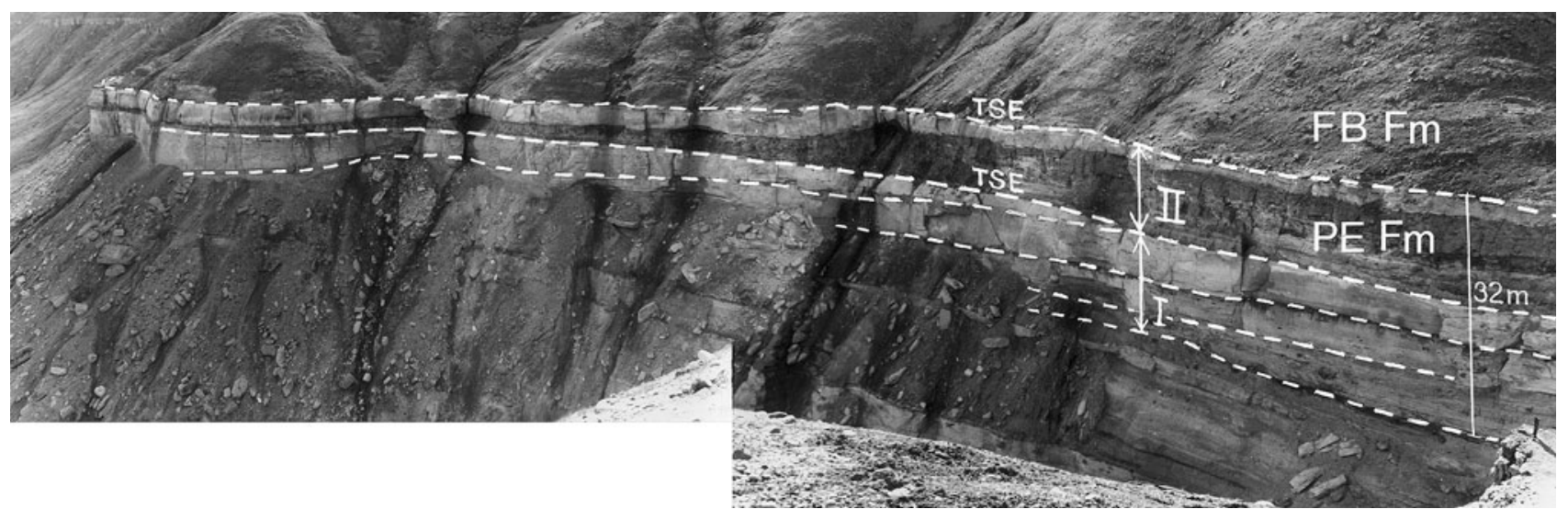

Fig. 28. The two clinoform units (association E) of the Ugleelv Member (Fig. 27). The view is towards the south. The two units are indicated as I and II. The base of the lower unit (I) is shown by the lowermost dashed line to the right. The top of the lower unit is dashed and is marked TSE. Clinoforms in the lower unit are indicated by the intervening dashed lines. The top of unit II is marked TSE and forms the top surface in Fig. 27. PE Fm, uppermost Pelion Formation; FB Fm, basal part of Fossilbjerget Formation. Locality 4 (Fig. 2).

isp., and Phycodes isp. of the Cochlichnus and Diplocraterion habichi ichnocoenoses of Heinberg \& Birkelund (1984).

The clinoform beds were formed by progradation of thick marine sandbodies towards the ESE. The coarse grain size suggests that deposition took place in connection with shoreface progradation, and that powerful currents, which probably periodically reached $1-1.5$ $\mathrm{m} / \mathrm{s}$ (indicated by the presence of traction-transported coarse sand), shaped the clinoform beds. The fossil assemblage indicates a fully marine environment. The depositional environment was tidally-influenced and shallow marine. The coexistence of small- and large-

\section{Facing page:}

Fig. 27. Sections measured through the clinoform complex (association $\mathbf{E}$ ) of the Ugleelv Member, exposed at localities 3 and 4 (Fig. 2), extending for $11 \mathrm{~km}$ in a north-south direction. The ammonites found just below the clinoform complex belong to the Cranocephalites borealis $\beta$ faunal horizon ( $\mathbf{1 b}$ ); the ammonite faunal horizons (1-21) shown on this and subsequent figures are listed in full on Fig. 37. A Cranocephalites indistinctus fauna is found in the basal beds of the lower clinoform unit (2), a Cranocephalites intermissus fauna (3) is found high in the unit, and a Cranocephalites gracilis fauna (4) is found on top of the lower unit at locality 4 , and on the top of the upper unit throughout the area. Biostratigraphical correlation to locality 6 (to the north) and locality 2 (to the south) is indicated. To the north, at locality 6A, Cranocephalites carlsbergensis (5) occurs immediately above the Cranocephalites borealis $\beta$ fauna. 9a indicates the Arctocephalites delicatus faunal horizon. For full legend, see p. 823.

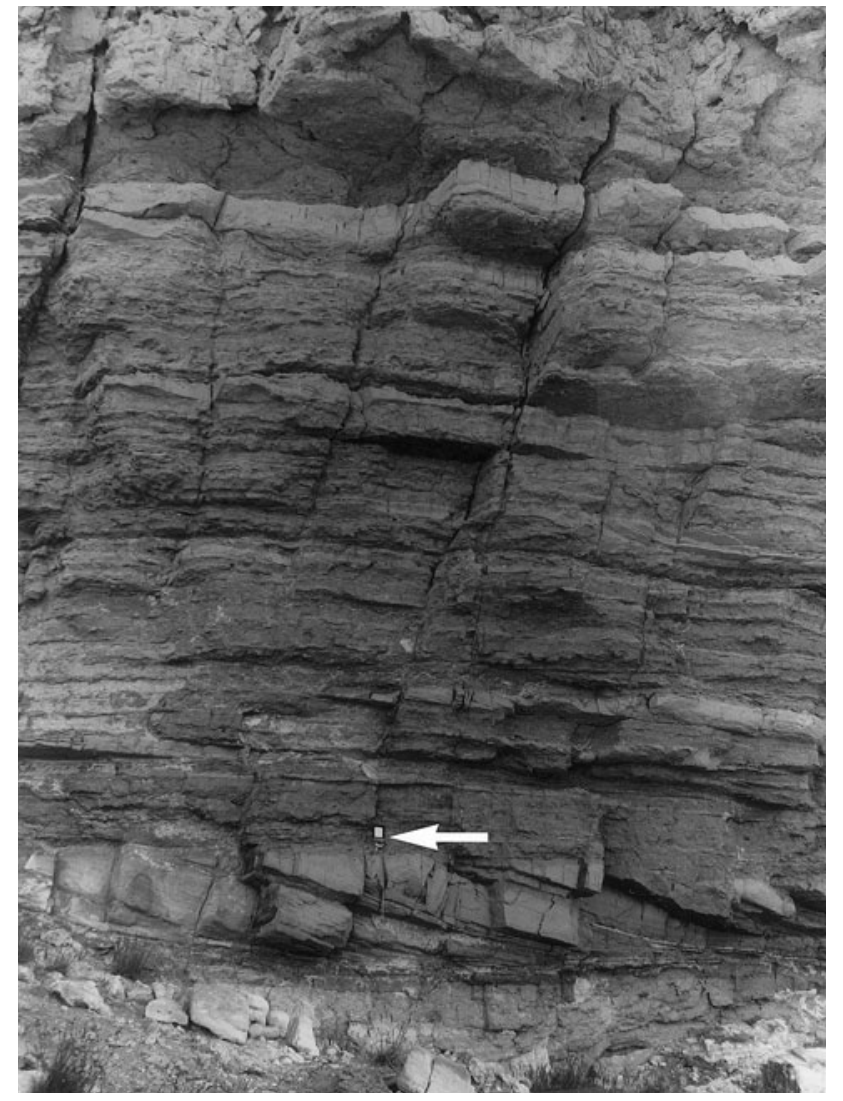

Fig. 29. Bottomsets of the lower clinoform unit (Fig. 27). Compass for scale (arrow). The view is towards the east. A tidal megaripple is seen below the compass; it shows bundled foresets, with azimuths towards the south. Bioturbated sandstones occur above the mega-ripple and become increasingly burrowed upwards, terminating in a $100 \%$ bioturbated sandstone; trace fossils recognised are Diplocraterion habichi, Skolithos isp. and Thalassinoides suevica. Pelion Formation, locality 3 (Fig. 2). 
scale wave-ripples and swales in the topset deposits suggests that the water depth was above fair-weather wave base in a shoaling wave environment. Wave-eroded intraset-boundaries indicate periods with no net deposition. Symmetrical mega-ripples were formed by storm waves, and plane-bedded intrasets were formed by suspension fall-out. Large-scale inactivity and reactivation surfaces internally in the clinoform beds indicate lateral shifting of the active depositional surface during deposition, or minor sea-level changes. The upper surface of the clinoform beds was erosionally planed off during transgressive marine erosion succeeding deposition of each unit. Marine erosion was followed by marked increase in the water depth, reflected by the presence of a strongly burrowed marine surface of erosion, overlain by burrowed calcareous offshore siltstones of facies 5 .

Although the internal sedimentary structures of the clinoform beds closely resemble those observed on active depositional surfaces of modern offshore tidal sand bars, they are not analogous (Surlyk \& Noe-Nygaard 1991). A comparable setting may, however, occur in the modern Niger delta, where a tabular, $20 \mathrm{~km}$ wide sandy, shoreface attached sand unit occurs at 5-10 m water depth in front of a marine, reworked, prograding delta (Allen 1965; Oomkens 1974). Similar high-angle clinoform beds are characteristic of the Volgian Raukelv Formation of southern Jameson Land and are inter-
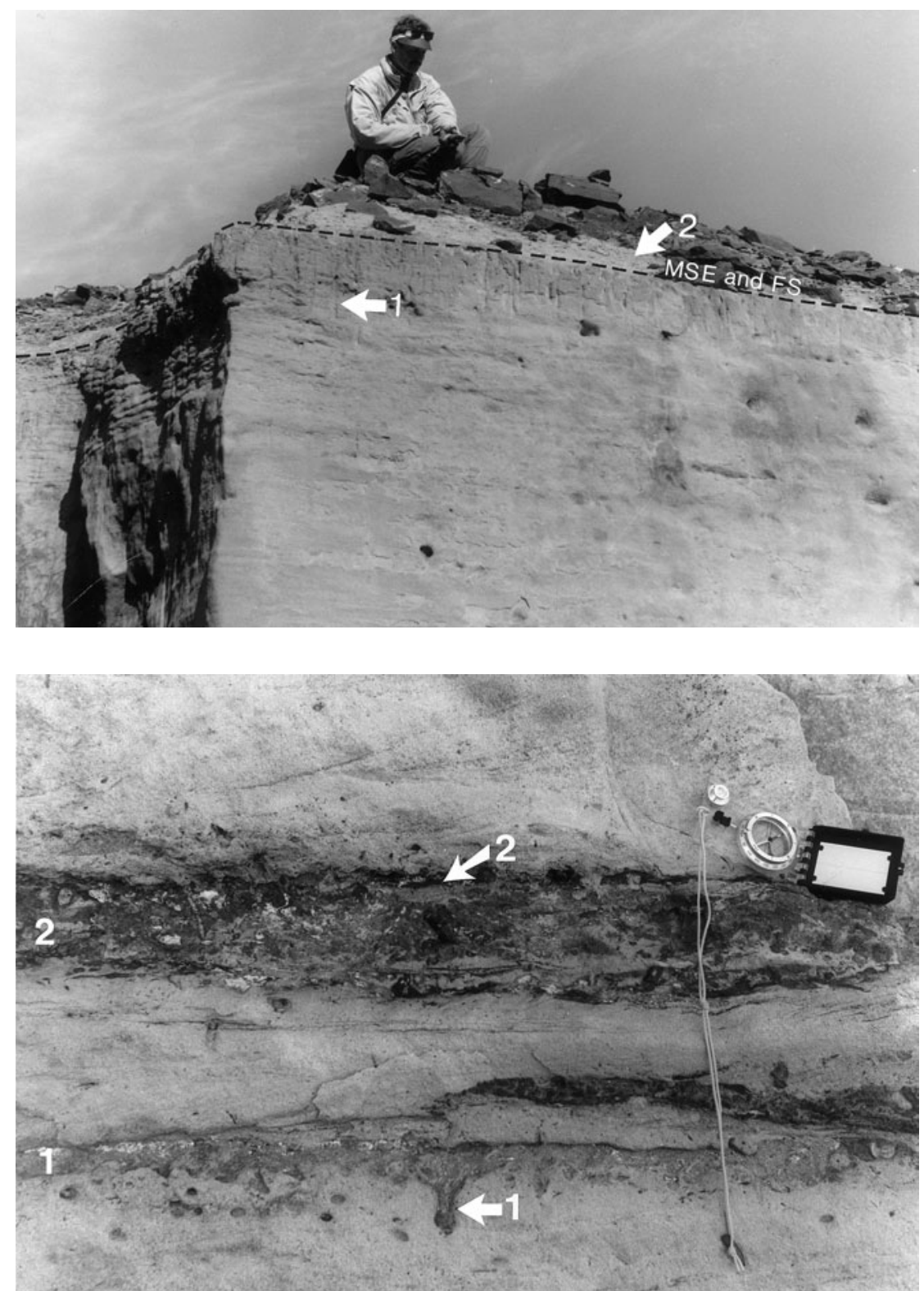

Fig. 30. A coincident marine surface of erosion (MSE) and flooding surface (FS), at the top of a prograding clinoform complex. Vertical Diplocraterion habichi and Monocraterion tentaculatum descend in large numbers from the surface (arrow 1). The uppermost $0.3 \mathrm{~m}$ of the clinoform bed show an upwards increase in the degree of carbonate cementation (calcite, dolomite and ankerite). The MSE/FS is overlain by offshore siltstones of the Fossilbjerget Formation (arrow 2), which are calcareous in the lowermost $0.1-0.2 \mathrm{~m}$. Pelion Formation, locality 4 (Fig. 2).

Fig. 31. A clinoform abandonment zone showing two levels of biological colonisation $(\mathbf{1}, \mathbf{2})$, separated by cross-bedded, medium-grained sandstones. Dominant trace fossils are Diplocraterion isp. (arrow 1) and Thalassinoides isp. (arrow 2). The dark colour of the bioturbated levels is caused by the presence of carbonaceous debris, mud and carbonate cement. Pelion Formation, locality 3 (Fig. 2). 
preted as marine-reworked shelf-margin wedges formed during sea-level lowstand (Surlyk \& Noe-Nygaard 1995).

\section{F. Offshore association}

Thin offshore deposits that form part of shoreface associations have been described and interpreted in the shoreface section. Thick offshore deposits characterise the Fossilbjerget Formation, and are described and interpreted below (Fig. 32). The offshore association consists of sediments deposited from suspension fall-out, at some levels influenced by wave-agitation and currents (facies 5, 6, 10). Marine body fossils are abundant throughout, and are commonly concentrated at surfaces capping coarsening-upwards units. Offshore sediments immediately overlying such surfaces may contain Zoophycos laminatus? and Phoebichnus trochoides.

The facies associations of the Fossilbjerget Formation show a proximal-distal, north-south transition from shoreface and sand sheet associations in northern Jameson Land (facies 7, 9, 10) to fully offshore associations in central and southern Jameson Land (facies 10; Figs 32, 33). In southern Jameson Land, the offshore deposits consist of structureless and laminated siltstones and mudstones with bands and lenses of fossil-rich carbonate and phosphate-cemented siltstones. An overall fining-upwards tendency has been recorded in these deposits, and deposition took place well below stormwave base. In central Jameson Land (Fig. 2, locality 5), the offshore association is up to $10 \mathrm{~m}$ thick, and generally coarsens upwards, with an overall upwards increase in sand content. The association wedges out towards the south, and is generally less than $1 \mathrm{~m}$ thick at localities 3 and 4 . It may internally contain coarsening-upwards units, grading upwards from structureless or laminated siltstones to fine-grained, structureless, micaceous, carbonaceous and glauconitic sandstones. Some units are very rich in fossils, and their upper parts may contain ammonites, embedded at all angles, and brachiopods and bivalves, commonly in life position. Proximal offshore units are exposed at locality 9, where a vertical stacking of offshore, shoreface, and shallow marine, nearshore sand sheet associations occur (Fig. 33).

The association is interpreted as the fully marine, distal offshore part of progradational sandy shoreface units, deposited near or below storm wave-base by suspension fall-out. The thin coarsening-upwards units may reflect minor progradational events. The overall southwards fining and tapering of the offshore deposits of the Fossilbjerget Formation reflect sediment influx

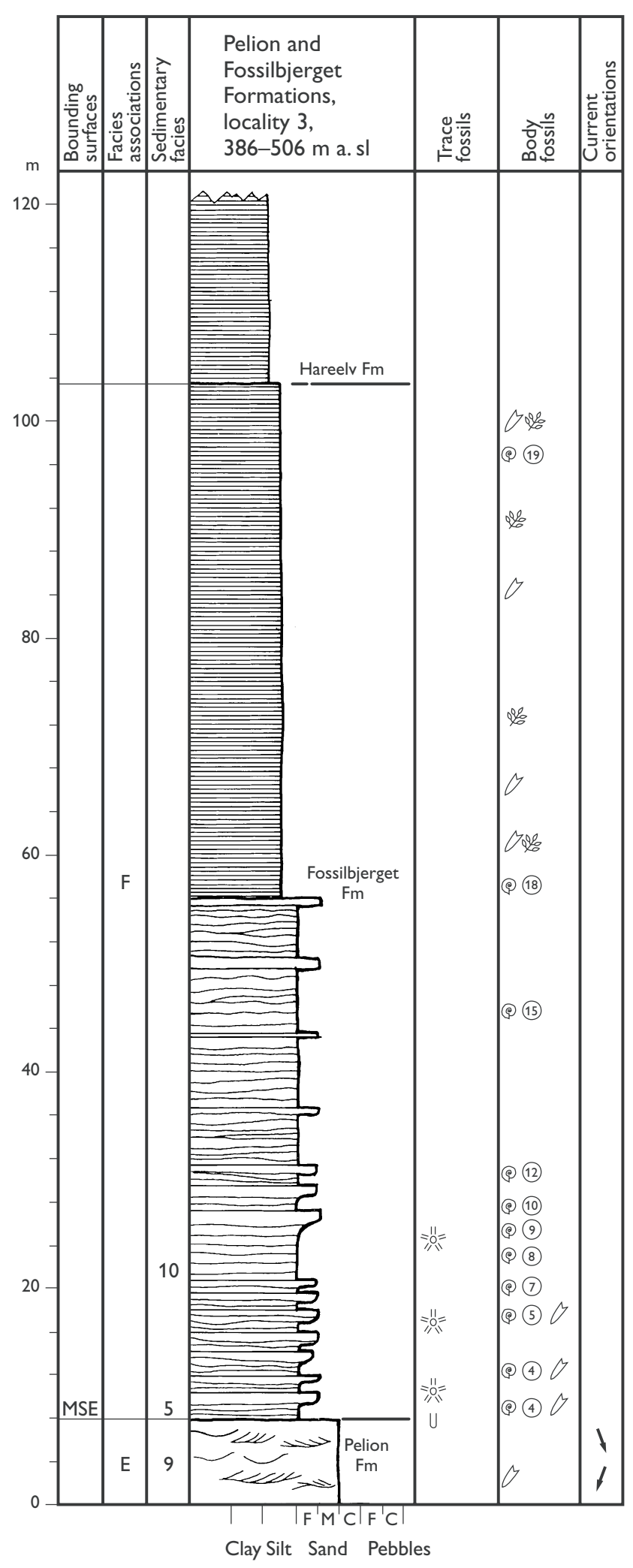

Fig. 32. Offshore deposits (association F) of the Fossilbjerget Formation, locality 3 . Ammonite horizons are indicated; the numbers refer to the faunal horizons listed in full on Fig. 37. For legend, see p. 823. 


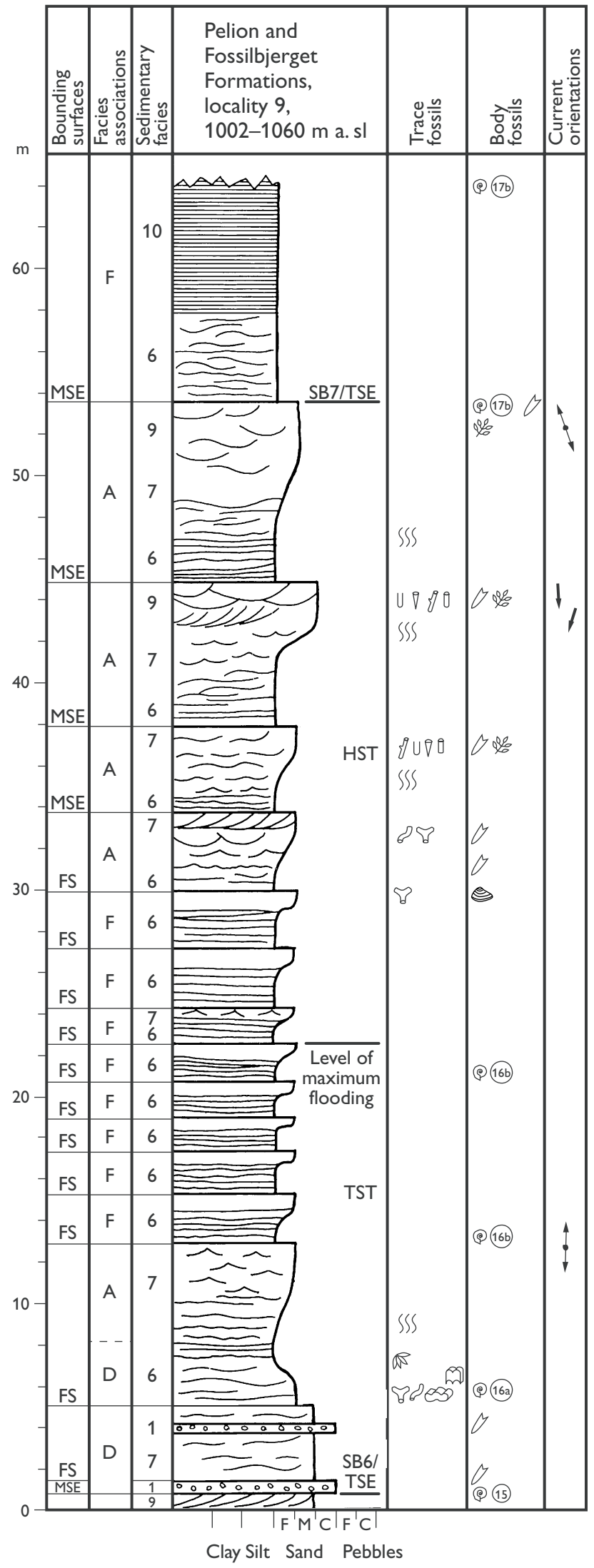

to the offshore environment from the north, and distal condensation. Biostratigraphical data show that the distal deposits of southern Jameson Land are strongly condensed at several levels (Fig. 6). The degree of condensation decreases gradually towards the north, and the area of condensation expanded northwards through time; the upper part of the Fossilbjerget Formation consists mainly of condensed, offshore facies throughout the study area (Surlyk et al. 1973, 1993; Birkelund 1975; Heinberg \& Birkelund 1984; Surlyk 1991, 2003, this volume; Callomon 1993).

\section{Sequence stratigraphy}

A hierarchy of depositional sequences is recognised in the Pelion and Fossilbjerget Formations (Surlyk 1990b, 1991; Engkilde \& Surlyk 1993; Surlyk et al. 1993; Engkilde 1994). A total of 28 sequences are recognised and are expressed by the facies associations. They are stacked into eight low-order composite sequences (P1-8, Fig. 6), each containing 3-5 higher order sequences, formed by shoreface progradation. The composite low-order sequences each cover a time span of 1-2 Ma, in the range of the third-order composite depositional sequences of Mitchum \& Van Wagoner (1991) and are referred to as such in the following discussion. P1-8 are defined by the stacking pattern of the constituent high-order

Fig. 33. Offshore (F) and shoreface (A) associations of the Fossilbjerget Formation. Ammonite horizons are indicated. This section is situated in a more proximal position than that shown in Fig. 32, and consists of stacked shallow offshore and shoreface associations. From 1-23 m, the section reflects a backstepping trend (transgressive systems tract, TST), and from $23-54 \mathrm{~m}$ a forestepping trend (highstand systems tract, HST), as proximal shoreface units overlie distal offshore units. At $54 \mathrm{~m}$, an abrupt transition occurs from shoreface to offshore units. This section illustrates the interdigitation of the Pelion Formation with the Fossilbjerget Formation; the Pelion Formation lowermost in the section $(0-5 \mathrm{~m})$ is succeeded by sediments of the Fossilbjerget Formation (5-23 m), which, in turn, are overlain by sandy Pelion Formation deposits (23-54 m) referred to the Parnas Member (Surlyk 2003, this volume, fig. 5). Offshore mud-rich sediments of the Fossilbjerget Formation resume above $54 \mathrm{~m}$. Locality 9 (Fig. 2). The deposits belong to the composite sequence $\mathrm{P} 6$, which is bounded by coincident sequence boundaries $(\mathbf{S B})$ and transgressive surfaces of erosion (TSE), SB6/TSE beneath and SB7/TSE above. For legend, see p. 823. 
sequences and by the nature and extent of their bounding surfaces. The average duration of a high order sequence is about 360,000 years, in the range of the fourth-order depositional sequences of Mitchum \& Van Wagoner (1991). They are referred to as sequences or simple sequences.

The sequence boundaries of the composite sequences are defined by significant turn-around points in the stacking pattern of the constituent sequences (Fig. 6). Boundaries of composite sequences are interpreted to represent periods of widespread subaerial exposure in the basin, indirectly reflected by the texture and distribution of overlying lag deposits, areal distribution of underlying shoreface deposits, and in some cases directly by the biostratigraphic duration of the associated hiatuses.

The simple sequences form laterally linked sedimentary bodies, bounded by marine surfaces of erosion in shoreface and near-shore successions and correlative conformities in distal, offshore deposits. The marine erosion surfaces, which top most of the sequences in proximal areas are commonly overlain by laterally extensive pebble and sandstone lags (facies 1 , 2) formed by transgressive erosion and winnowing of underlying deposits, and the surfaces are thus ravinement surfaces. The lags are generally significantly coarser-grained than the deposits below, implying that relatively large volumes of sediments have been eroded away (Engkilde 1994). They represent reworked fluvial, coarse delta-front, or adjacent shoreface deposits reworked during transgression, and their presence sug- gests that a zone of emergence, sedimentary bypass or erosion was formed after shoreface progradation. The lags thus represent a significant basinwards shift in facies. The lower boundary of a marine lag is accordingly interpreted as a sequence boundary, overprinted by a younger marine ravinement surface. In more distal areas, the sequence boundaries are expressed as submarine erosion surfaces and their correlative conformities.

The successions between the sequence boundaries are regarded as small-scale sequences (sensu Van Wagoner et al. 1990; Fig. 34). The top of a lag is interpreted as a marine drowning surface, formed at the time when the water depth became too great for wave reworking. The drowning surfaces do not represent significant hiatuses, but are levels of slow deposition and condensation. They are commonly overlain by laterally widespread mudstones, marls or fine-grained sandstones deposited below storm wave base during the time of maximum flooding. Overlying shoreface deposits, forming the bulk of the sequences in proximal areas, are generally 5-15 m thick, and represent southwards progradation over several hundred kilometres without significant changes in thickness and facies. A general thickening of the most basinally positioned parts of the shoreface/tidal inlet units occurs, however, and they may reach up to $35 \mathrm{~m}$ in thickness at localities 5, 6, 6A and 7. The basin deepened gradually towards the south, along the basin axis, as indicated by the large-scale facies development. The shoreface/ tidal inlet units are of approximately equal thickness

$\mathrm{N}$

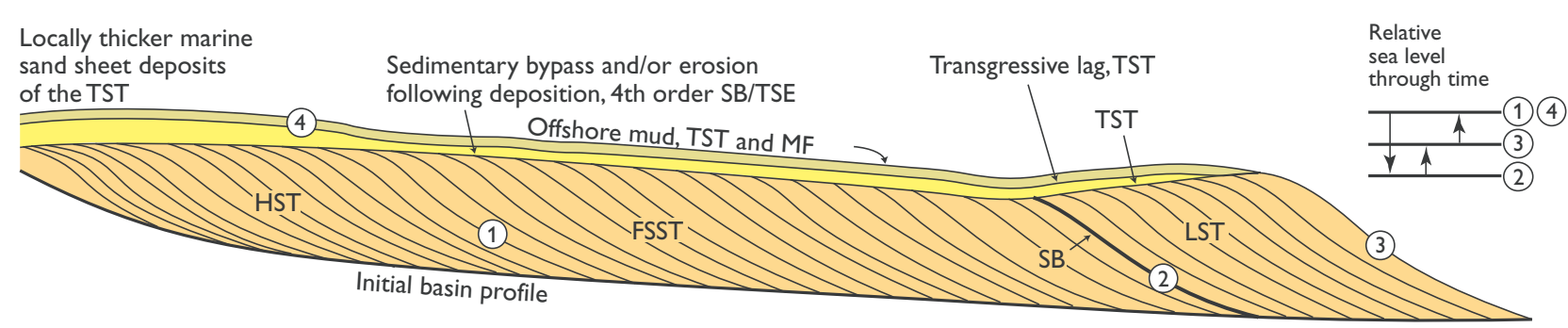

Fig. 34. Relative position of the systems tracts of the high-order sequences in the Jameson Land Basin. The north-south extent of the progradational systems ranges between 150 and $200 \mathrm{~km}$; the dip of depositional slopes is exaggerated. The relative sea-level stand and the lateral translation of the depositional system are indicated schematically for times $\mathbf{1}-\mathbf{4}$. Progradation took place during slow rise or stillstand (time 1), followed by fall (time 1-2), and terminated by slow rise of relative sea level (times 2-3). Backstepping took place during the rise in relative sea level (times 3-4). It has not been possible to separate the highstand (HST) and the falling stage (FSST) systems tracts (terminology of Plint \& Nummedal 2000), as there are no significant differences in vertical position. This is due to the low-gradient basin geometry, and to wave-ravinement processes active during transgression. In the field, sandstones of the late lowstand systems tracts (LST) tend to be significantly thicker than those of the HST and FSST. SB, sequence boundary; TSE, transgressive surface of erosion; TST, transgressive systems tract; MF, level of maximum flooding. 


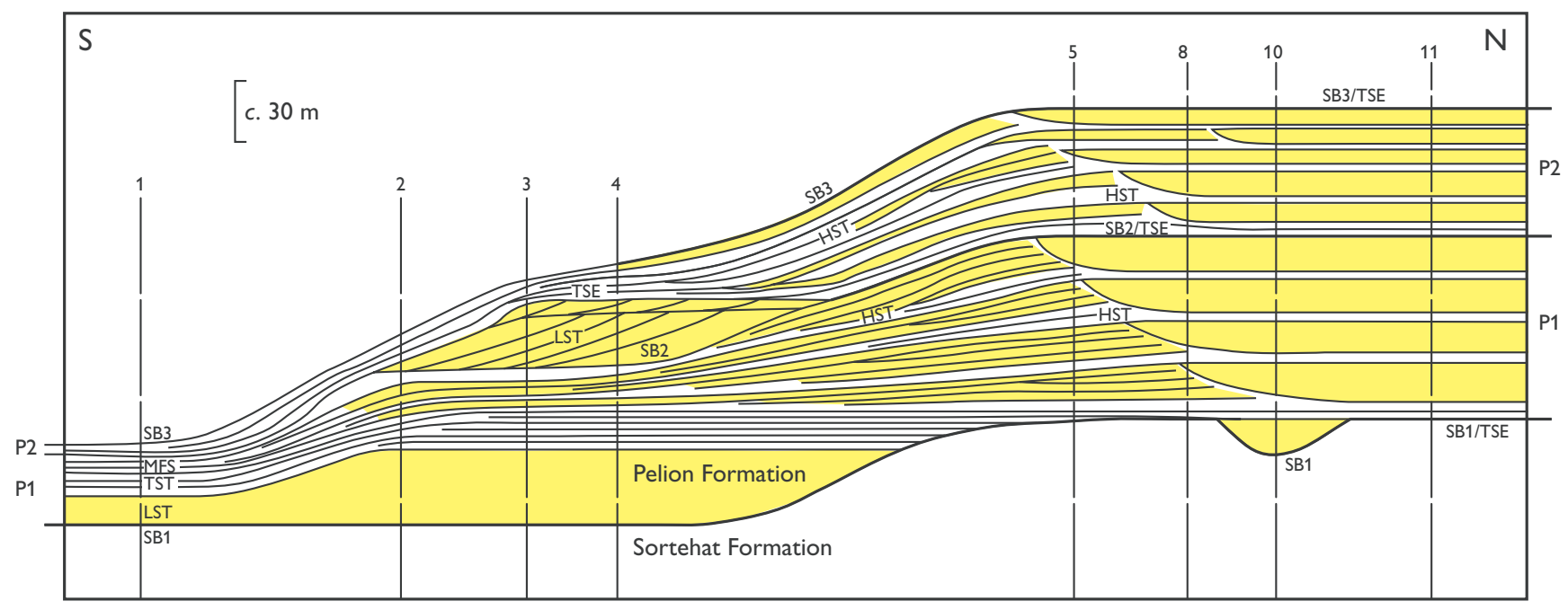

Fig. 35. Schematic reconstruction of the depositional pattern of the composite sequences P1 and P2, based on sedimentological logs (indicated by vertical lines) and biostratigraphical data (Figs 37A, B); the section represents a lateral S-N distance of $c$. $120 \mathrm{~km}$. The yellow colour indicates shallow marine fine- to coarse-grained sandstones, parallel lines represent mainly offshore laminated siltstones and fine-grained sandstones. The sandstone units on the right side of the diagram are shoreface and estuarine units, forming high-order sequences (P1A-D and P2A-E). The estuarine sandstones are interpreted to fill minor incised river valleys and were deposited during P1 late lowstand and early transgressive times. The northwards extent of the sandstones of the lowstand systems tracts (LST) of P1 and P2, on the right side of the diagram, is hypothetical, due to lack of exposures between localities 4 and 5 . The coarse grain size of the sandstones in the LST of sequence P2 suggests that the deposits were fed directly by rivers, or linked to a shoreline to the north, and formed a laterally widespread submarine deltaic platform. SB, sequence boundary; TSE, transgressive surface of erosion; TST, transgressive systems tract; MFS, maximum flooding surface; HST, highstand systems tract.

throughout most of northern Jameson Land, except in the easternmost part where they are thicker. In central Jameson Land, the signature of the sequences is gradually lost, and the depositional pattern of the composite sequence is dominant.

The overall geometry of the sequences is interpreted to reflect progradation during stillstand, fall, and early rise of relative sea level (Fig. 34). The bulk of the sandstone part of the sequences is accordingly interpreted to represent falling stage system tracts (terminology of Plint \& Nummedal 2000), as the sandstones are relatively thin over large areas, without any offshore thickening, and as they are capped by complex erosion surfaces. The thicker distal parts of the sequences, composed of sandstone, are interpreted as lowstand systems tracts, deposited during stillstand and early rise in relative sea level. The lowstand systems tracts are attached to the falling stage systems tracts (Fig. 34). When the rate of relative sea-level rise became larger than the rate of sediment accumulation, the shoreface system rapidly backstepped towards the basin margins and up to several hundred kilometres northwards up the basin axis. Early highstand deltaic deposits are thus to be expected to occur in the marginal areas.

\section{Composite depositional sequences}

The eight composite depositional sequences of the Pelion-Fossilbjerget couplet are described from below (P1-8), including biostratigraphy, boundary relationships, large-scale depositional geometries (systems tracts), and internal architecture. Constituent higher order sequences are indicated by a letter suffix, P1A, $\mathrm{P} 1 \mathrm{~B}$, etc. All systems tracts of a depositional sequence are not necessary represented at all localities, and successive systems tracts do not necessarily stack vertically (Posamentier \& Vail 1988; Posamentier et al. 1988). Throughout northern Jameson Land, the composite sequences are highly asymmetric, volumetrically dominated by the highstand systems tracts (Figs 35, 36). This is thought to reflect the low-gradient basin topography, high sediment influx and efficient sediment transport. After filling of the accommodation space in 


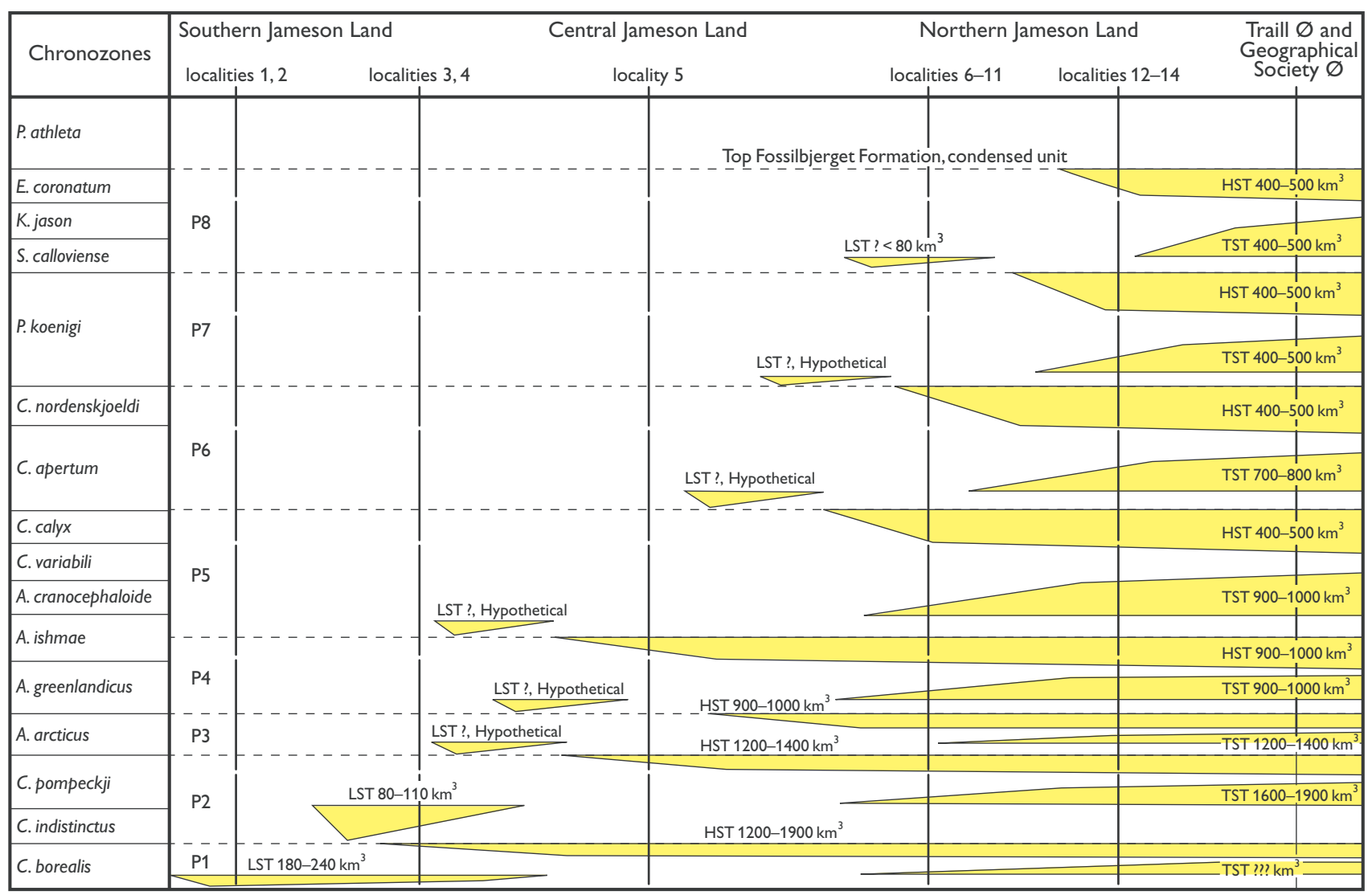

Fig. 36. Distribution of Pelion Formation sandstones in time and space in the Jameson Land Basin. Estimates of sandstone volumes (yellow) in the different third order systems tracts are indicated. Inferred lowstand deposits are shown (also with estimated volumes, where feasible). The total sandstone volume in the formation is estimated to be in the range of $12,000-15,000 \mathrm{~km}^{3}$. The durations of the highstand and the transgressive systems tracts in a composite sequence are postulated to be of the same order. Thick deposits of the transgressive systems tracts are predicted to have been deposited in the Traill $\varnothing$ - Geographical Society $\varnothing$ region. No major variation in the rate of sediment influx is expected to occur at the scale of a single sequence, and the sandstone volumes of the two systems tracts are accordingly estimated to be of the same order.

proximal areas during early highstand, a wide subaerial bypass zone was developed during late highstand, and rivers transported most sediment volumes to the rapidly prograding shorefaces. The shoreface successions were deposited during repeated higher order sea-level falls, and are stacked vertically in a forewards-stepping manner throughout northern Jameson Land. Further offshore in central Jameson Land, the higher order pattern is less distinct, and very thick coarsening-upwards offshore-shoreface units represent the distal parts of the highstand systems tracts of the composite sequences. The bulk of the transgressive systems tracts of the composite sequences are predicted to exist in the most marginal areas, in Milne Land to the west and in the western and northern parts of the Traill $\varnothing$ - Geographical Society $\varnothing$ - Hold with Hope area to the north (Fig. 36).
Sequence P1, Upper Bajocian (Figs 6, 35, 36, 37A, 38A)

\section{P1: Basal sequence boundary, SB1}

In Jameson Land, the basal sequence boundary (SB1) is of Late Bajocian age, corresponding to the base of the C. borealis Chronozone (Figs 6, 37A; Surlyk et al. 1973, 1993; Surlyk 1990a, b, 1991, 2003, this volume). This sequence boundary is present throughout central East Greenland. The ammonite fauna (Cranocephalites borealis) belongs to the Boreal faunal realm, which cannot be directly correlated with the Tethyan faunal realm. The $C$. borealis Chronozone is referred to the Upper Bajocian (Callomon 1961, 1993). It is stressed that correlation to the European Bajocian-Bathonian Stages is uncertain and the recognition of the Lower and Upper 


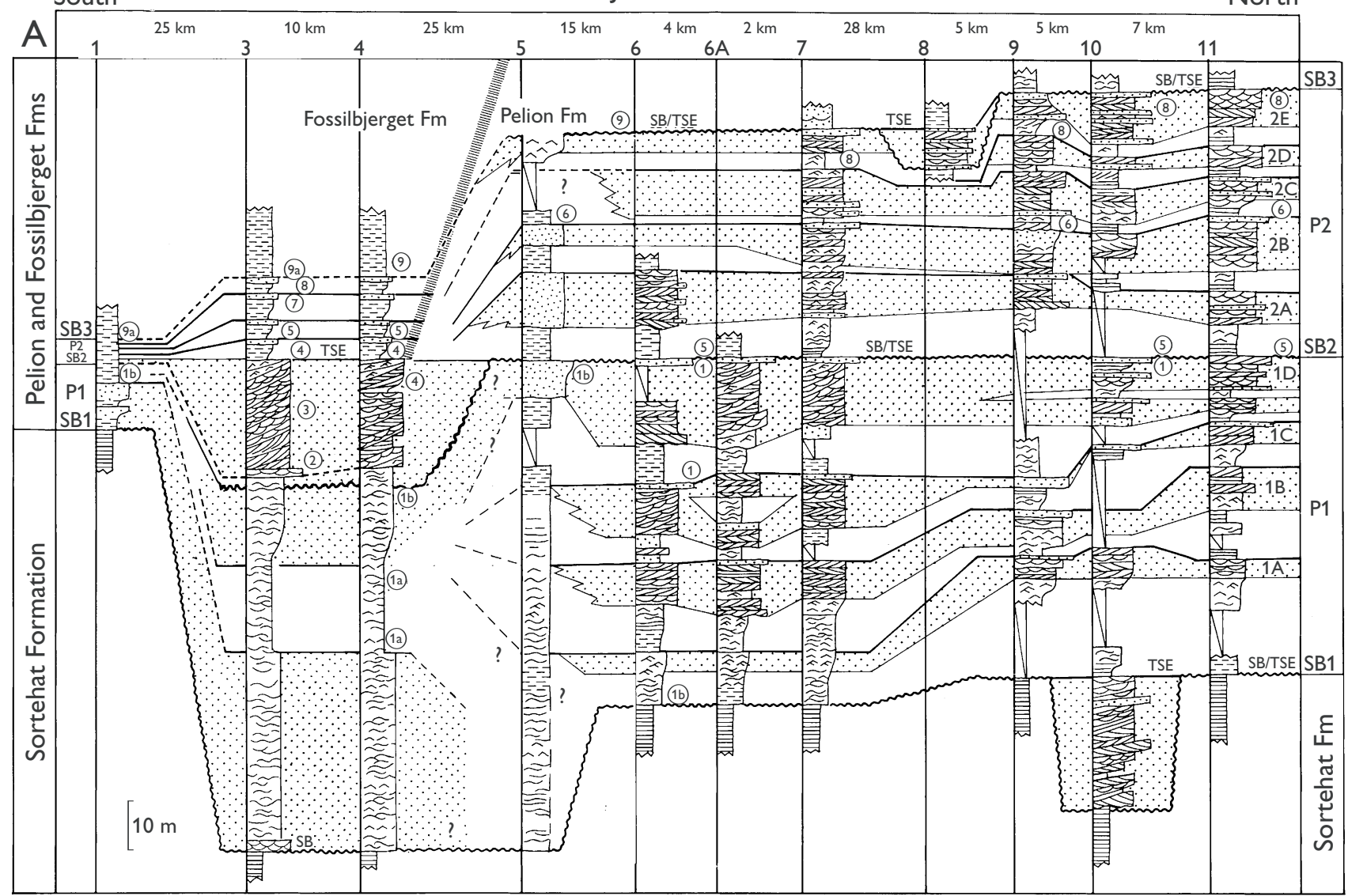

\section{Ammonite faunal horizons}

\begin{tabular}{|c|c|c|c|}
\hline \multicolumn{2}{|c|}{$1 \mathrm{a}, \mathrm{b}$ C. borealis $\alpha$ and $\beta$} & \multirow[t]{2}{*}{13} & \multirow{2}{*}{$\begin{array}{l}\text { A. cranocephaloide } \\
\text { and/or K. tychonis }\end{array}$} \\
\hline 2 & C. indistinctus & & \\
\hline 3 & C. intermissus & 14 & $\begin{array}{l}\text { K. tychonis and/or } \\
\text { K. rosenkrantzi }\end{array}$ \\
\hline 4 & C. gracilis & 15 & K. peramplus and/or \\
\hline 5 & C. carlsbergensis & & K. vardekloeftensis \\
\hline 6 & C. furcatus & $16 \mathrm{a}$ & C. apertum $\alpha$ \\
\hline 7 & C. pompeckji & $16 b$ & C. apertum $\beta$ \\
\hline 8 & C. episcopalis & $17 \mathrm{a}$ & C. nordenskjoeldi $\alpha$ \\
\hline 9 & A. arcticus & $17 b$ & C. nordenskjoeldi $\beta$ \\
\hline $9 a$ & A. delicatus & 18 & P. koenigi Chronozone \\
\hline $9 b$ & A. micrumbilicatus & 19 & S. calloviense \\
\hline 0 & A. greenlandicus & 20 & K. jason \\
\hline $10 \mathrm{a}$ & A. freboldi & 21 & L. keyserlingi \\
\hline 11 & A. harlandi & & \\
\hline $12 a$ & A. ishmae $\alpha$ & & \\
\hline 20 & $\begin{array}{l}\text { A. ishmae } \beta \text { and/or } \\
\text { A. crassiplicatum }\end{array}$ & & \\
\hline
\end{tabular}

Major facies and key surfaces

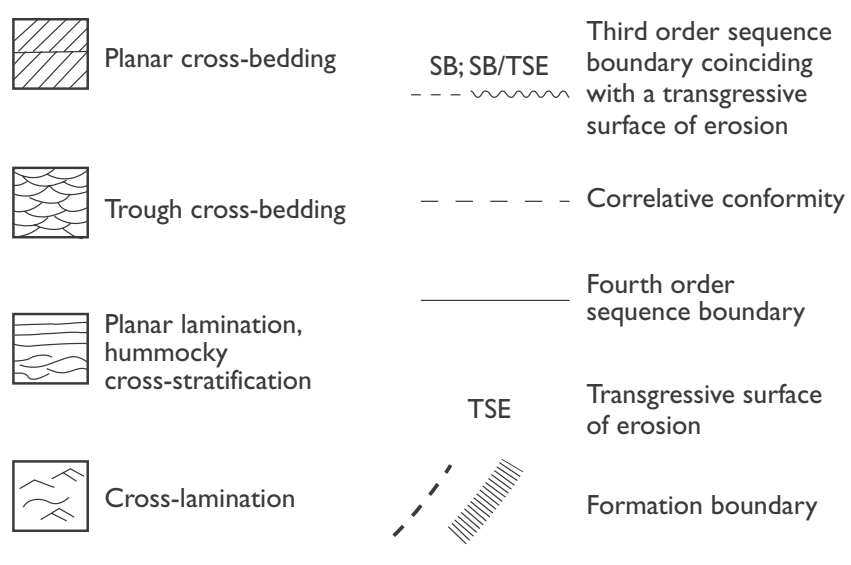

Middle to upper shoreface coarse- and medium-grained sandstones

Offshore and lower shoreface fine-grained sandstones and siltstones 

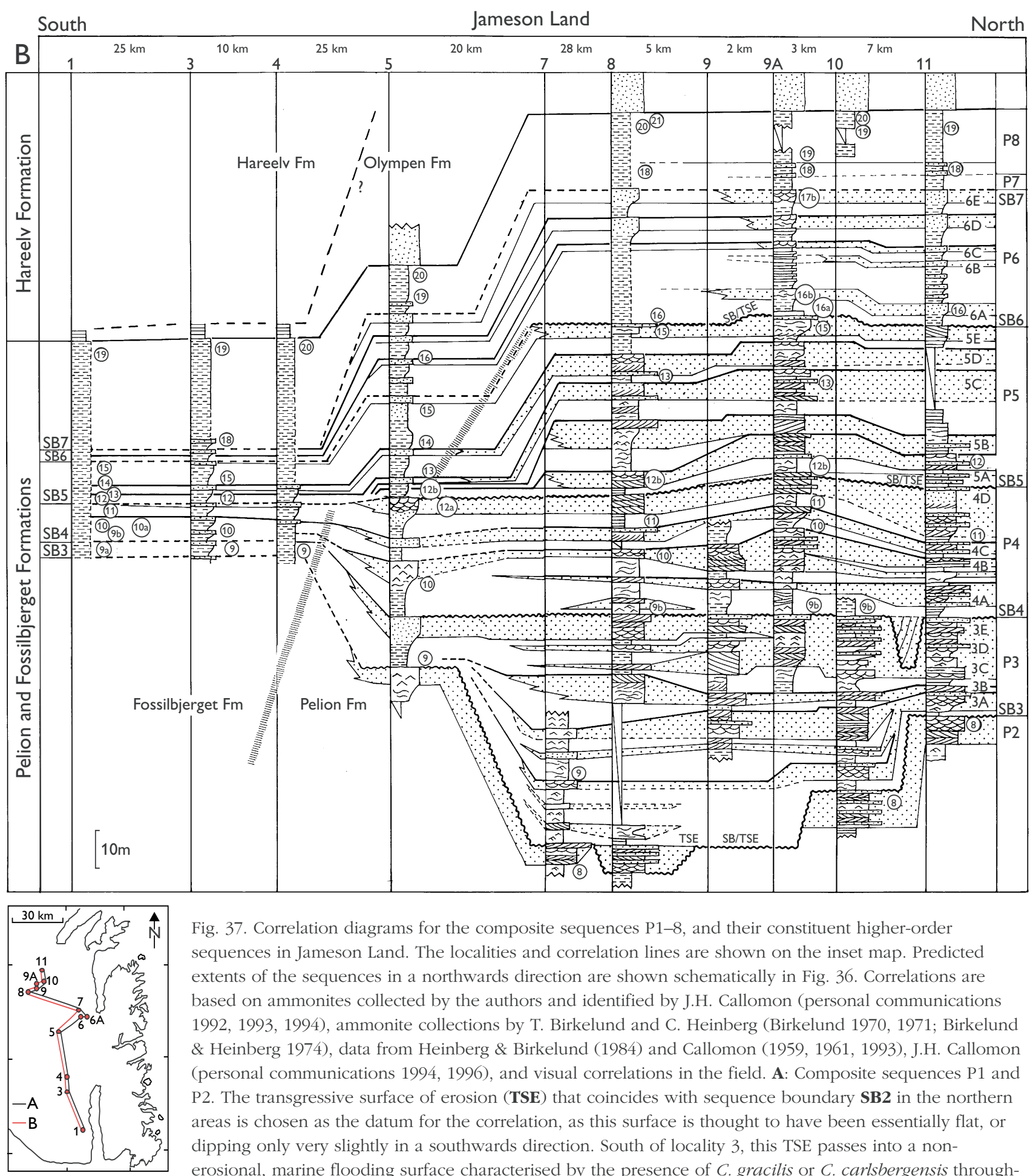

Fig. 37. Correlation diagrams for the composite sequences P1-8, and their constituent higher-order sequences in Jameson Land. The localities and correlation lines are shown on the inset map. Predicted extents of the sequences in a northwards direction are shown schematically in Fig. 36. Correlations are based on ammonites collected by the authors and identified by J.H. Callomon (personal communications 1992, 1993, 1994), ammonite collections by T. Birkelund and C. Heinberg (Birkelund 1970, 1971; Birkelund \& Heinberg 1974), data from Heinberg \& Birkelund (1984) and Callomon (1959, 1961, 1993), J.H. Callomon (personal communications 1994, 1996), and visual correlations in the field. A: Composite sequences P1 and P2. The transgressive surface of erosion (TSE) that coincides with sequence boundary SB2 in the northern areas is chosen as the datum for the correlation, as this surface is thought to have been essentially flat, or dipping only very slightly in a southwards direction. South of locality 3 , this TSE passes into a nonerosional, marine flooding surface characterised by the presence of $C$. gracilis or C. carlsbergensis throughout the region. B: Composite sequences P3-8. The transgressive surface of erosion (TSE) that coincides with SB4 in the northern areas (locality 5 and northwards) is chosen as datum for the correlation of the northern sections, as it is easily identified in the field and occurs in one faunal horizon $(A$.

micrumbilicatus) throughout the area. In central and south Jameson Land, the TSE that coincides with SB5 at locality 5 , is chosen as the datum, as it is a very distinct surface in the field. At locality 5 , the surface forms the boundary between the Pelion and Fossilbjerget Formations. South of locality 5, the surface is a non-erosional flooding surface, occurring in one ammonite subzone ( $A$. ishmae $\beta$ ) throughout the area. Some of the numbers referring to faunal horizons 9,12 and 16 do not have a suffix; this indicates that the ammonite in question may be one of two variants, $\alpha$ or $\beta$. 
Bajocian and Bathonian in East Greenland is a best estimate of Callomon (1993). The internal zonal correlation within the framework of the Boreal Middle Jurassic ammonite zonation is, however, very precise (Surlyk et al. 1973; Callomon 1993). Unpublished ${ }^{87} \mathrm{Sr} /{ }^{86} \mathrm{Sr}$ values obtained from belemnites of the $C$. borealis Chronozone indicate a Late Bajocian age, by comparison with the ${ }^{87} \mathrm{Sr} /{ }^{86} \mathrm{Sr}$ isotope curve of Jones et al. (1994).

In Jameson Land, the Pelion Formation overlies the Sortehat Formation. ${ }^{87} \mathrm{Sr} /{ }^{86} \mathrm{Sr}$ data indicate that the Sortehat Formation at least in the southern and central part of Jameson Land includes the Aalenian - Lower Bajocian. Dinoflagellate data suggest that the Sortehat Formation covers the Aalenian and possibly part of the Bajocian (Underhill \& Partington 1993; Koppelhus \& Hansen 2003, this volume). Further north, on Traill $\varnothing$, the Pelion Formation rests on Upper Triassic redbeds of the Flemming Fjord Formation (Clemmensen 1980), indicating a northwards increase in the duration of the hiatus expressed by SB1 (Fig. 6). On northern Hold with Hope, the Pelion Formation overlies the Lower Triassic Wordie Creek Formation (Stemmerik et al. 1997; Vosgerau et al. in press a). In central and northern Jameson Land (Fig. 2, localities 5, 6, 6A, 7, 9, 11), SB1 is interpreted as a subaerial unconformity, coinciding with a transgressive surface of erosion (TSE). It appears as a sharp boundary, separating dark grey, shaly offshore siltstones of the Sortehat Formation from yellow, burrowed, wave-rippled shoreface sandstones, or laminated light grey, burrowed offshore siltstones and sandstones of the basal Pelion Formation. Mudstone clasts of the Sortehat Formation locally occur in the lower part of the Pelion Formation. SB1 is overlain by thin floodplain and estuarine deposits at locality 10, and the sequence boundary here coincides with the base of an incised valley (Figs 22, 23, 35, 37A). In southern Jameson Land, SB1 is represented by a marine regressive surface of erosion, which marks a significant basinwards shift of facies. SB1 here separates dark, silty mudstones of the Sortehat Formation from shallow marine coarsegrained siltstones and fine-grained sandstones of the Pelion Formation, which form a lowstand wedge.

\section{P1: Lowstand systems tract}

Estuarine deposits, up to $40 \mathrm{~m}$ thick, are preserved at locality 10, in northern Jameson Land, and are interpreted to form part of the lowstand systems tract. The deposits fill a valley incised into the Sortehat Formation during falling and low sea-level stand. The base of the valley forms SB1 (Figs 22, 23, 35, 37A). The estuarine deposits may belong to the $C$. borealis Chronozone, but no ammonites were found. The incised valley was formed by fluvial erosion, as indicated by the basal erosional remnants of floodplain deposits. Possible correlative fluvial conglomerates of the Bristol Elv Formation occur below marine sandstones of $C$. borealis Chron age on Traill $\varnothing$ and probably occupy a major incised valley complex (Therkelsen \& Surlyk in press).

In southern Jameson Land (Fig. 2, localities 1-4), southwards thinning basal silty sandstones of P1 form a 20-80 m thick lowstand systems tract of Late Bajocian age (Figs 35, 36, 37A). It consists of heavily burrowed fine- to medium-grained sandstones, with bivalves, gastropods, belemnites, ammonites and the trace fossils Diplocraterion parallelum, Diplocraterion habichi and Planolites isp. Petrified wood occurs in large quantities. The sandstones are generally poorly cemented. The upper part of the lowstand systems tract consists of sandstones showing well-preserved small- and largescale wave ripples, indicating deposition in a shallow marine, wave-influenced environment, above fairweather wave base, and is interpreted as comprising aggradational and progradational shoreface and shallow marine near-shore deposits. The lower boundary of the lowstand systems tract is an erosion surface, with a relief of up to $0.3 \mathrm{~m}$. The upper boundary is sharp and planar, and is covered by an abundance of belemnites, ammonites ( $C$. borealis $\alpha$ ), oysters and bivalves. Large numbers of Diplocraterion habichi descend from the surface. Overlying deposits consist of offshore siltstones of the Fossilbjerget Formation at localities 1 and 2 and silty sandstones of the Pelion Formation at localities 3 and 4 belonging to the transgressive systems tract. During the time span of the late lowstand and transgressive systems tracts, the active shoreface rapidly backstepped in a northwards direction. The sandstone volume of the lowstand systems tract is estimated at approximately $3 \mathrm{~km}^{3} / \mathrm{km}$ width in an E-W section. The complete width is not known, but a conservative estimate is $60-80 \mathrm{~km}$, giving a total sandstone volume in the range of 180-240 $\mathrm{km}^{3}$ (Fig. 36).

\section{P1: Transgressive systems tract}

The lowstand systems tract is capped by a marine erosion surface throughout southern and central Jameson Land, which forms the base of the transgressive systems tract. The transgressive systems tract is less than $6 \mathrm{~m}$ thick in south Jameson Land (Fig. 2, localities 1, 2), measured from the top of the lowstand deposits to the first occurrence of the $C$. borealis $\beta$ faunal horizon (Fig. 35) 

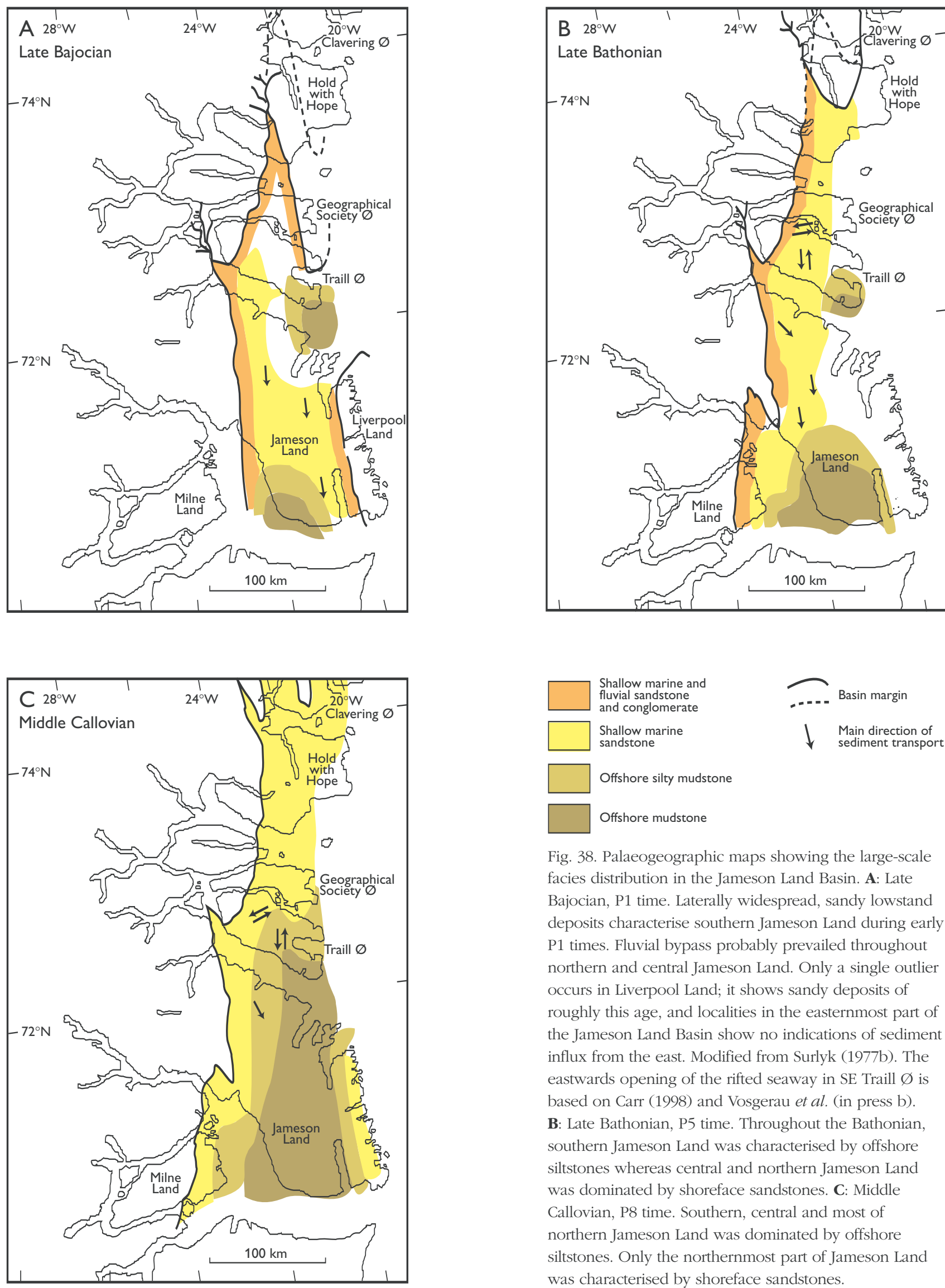

Offshore silty mudstone

Offshore mudstone

Fig. 38. Palaeogeographic maps showing the large-scale facies distribution in the Jameson Land Basin. A: Late Bajocian, P1 time. Laterally widespread, sandy lowstand deposits characterise southern Jameson Land during early P1 times. Fluvial bypass probably prevailed throughout northern and central Jameson Land. Only a single outlier occurs in Liverpool Land; it shows sandy deposits of roughly this age, and localities in the easternmost part of the Jameson Land Basin show no indications of sediment influx from the east. Modified from Surlyk (1977b). The eastwards opening of the rifted seaway in SE Traill $\varnothing$ is based on Carr (1998) and Vosgerau et al. (in press b).

B: Late Bathonian, P5 time. Throughout the Bathonian, southern Jameson Land was characterised by offshore siltstones whereas central and northern Jameson Land was dominated by shoreface sandstones. C: Middle Callovian, P8 time. Southern, central and most of northern Jameson Land was dominated by offshore siltstones. Only the northernmost part of Jameson Land was characterised by shoreface sandstones. 
and consists of dark grey fossiliferous, phosphatic and calcareous siltstone. At localities 3 and 4, the transgressive systems tract is $30 \mathrm{~m}$ thick, contains the $C$. borealis $\alpha$ fauna throughout, and consists mainly of dark grey, calcareous and phosphatic, laminated offshore siltstones. Only minor vertical changes in texture characterise these deposits, suggesting that deposition kept pace with sea-level rise. An overall upwards increase in the density of fossils is seen in the systems tract at localities 3 and 4, suggesting a decrease in sedimentation rate, an increase in biological production or simply better preservation. A general high degree of carbonate cementation characterises the deposits, in very sharp contrast to the underlying lowstand and overlying highstand deposits. In northern Jameson Land, the transgressive systems tract is represented only by a transgressive surface of erosion, a thin transgressive lag, or in some cases a thin transgressive sand sheet.

The $C$. borealis $\alpha$ fauna is not found north of locality 4 . At locality 5 , the lower part of the Pelion Formation is characterised by the $C$. borealis $\beta$ fauna. A presumed specimen of $C$. borealis $\beta$ (a microconch) was found immediately above SB1 at locality 6 , suggesting that the lack of the $C$. borealis $\alpha$ in the northern part of the study area is primary, reflecting the northwards onlap of the Pelion Formation. At localities 3 and 4, the transgressive systems tract is capped by a phosphatic, fossiliferous, calcareous siltstone bed, $0.2 \mathrm{~m}$ thick. The bed contains large numbers of belemnites, ammonites and bivalves, and is interpreted as a condensed unit, representing the time of maximum flooding (Fig. 30). The top surface of the bed is covered with $C$. borealis $\beta$. At localities 6, 6A and 7A, a heavily burrowed, calcareous siltstone bed is situated immediately above the basal SB1/TSE, and also represents the time of maximum flooding.

\section{P1: Highstand systems tract}

The highstand systems tract of P1 downlaps onto the upper condensed deposits of the transgressive systems tract. It contains $C$. borealis $\beta$ at locality 6 in eastern central Jameson Land, and throughout southern Jameson Land (Fig. 36). The deposits change from proximal, wave- and current-influenced shoreface and tidal inlet deposits, c. $120 \mathrm{~m}$ thick in the north (Fig. 2, localities $5,6,6 \mathrm{~A}, 7,9-11)$, to a shallow offshore, storm-influenced coarsening-upwards siltstone and sandstone unit, 20-30 m thick, further south (localities 3 and 4). Most distally, at locality 1 , the highstand deposits consist of a few metres of laminated offshore siltstones (Figs 35,
37A). At localities 3 and 4, the highstand systems tract is poorly cemented, and shows a significant upwards decrease in fossil content, in sharp contrast to the underlying deposits of the transgressive systems tract; the highstand systems tract is capped by a distinct marine erosion surface, covered with belemnites, ammonites and the bivalve Camptonectes broenlundi (Ravn 1911). The surface marks a major basinwards shift in facies, and is a sequence boundary, SB2. Diplocraterion habichi descends in large numbers from the surface, and the bivalve Modiolus strajeskianus (d'Orbigny 1845) is found in life position in high densities just below the surface, indicating an oxic, shallow marine environment (Fürsich 1984). Deposits of the highstand systems tract underlie the middle part of the Ugleelv Member at localities 3 and 4 .

Throughout northern Jameson Land, the highstand systems tract includes four simple sequences (P1A-D), which form a forwards-stepping sequence set (Figs 6, 35, 37A). From locality 5 and northwards, at least as far as locality 11 , the upper parts of the sequences show an increase in maximum grain size through P1A-D, reflecting the overall forestepping stacking order. In northern Jameson Land, the fourth order sequences are capped by coincident sequence boundaries and transgressive surfaces of erosion (SB/TSE), which are laterally most extensive and extend furthest offshore in sequence P1D. The maximum progradation point of shoreface units shifted more than $30 \mathrm{~km}$ towards the SSE during the time span covered by the highstand systems tract of P1 (from near locality 8 in northern central Jameson Land to south of locality 5 in central Jameson Land). The volume of the sandstones of the highstand systems tract in Jameson Land falls in the range of $1100-1400 \mathrm{~km}^{3}$ (deposits may have extended further to the east and west than the present outcrop belt), and the total sandstone volume of the systems tract is estimated at 1600-1900 km³ , assuming that sandy highstand deposits continue $120 \mathrm{~km}$ northwards into the Traill $\varnothing$ - Geographical Society $\varnothing$ area in an up to $100 \mathrm{~m}$ thick, $80 \mathrm{~km}$ wide, northwards tapering and thinning wedge (Fig. 36). In northern Geographical Society $\varnothing$, the stratigraphic interval equivalent to $\mathrm{P} 1$ is less than $30 \mathrm{~m}$ thick, from the basal onlap surface (SB1) to the first occurrence of Cranocephalites indistinctus which coincides with the base of P2 in Jameson Land. The section consists of a single unit coarsening-upwards from fine- to coarsegrained pebbly sandstone (A.G. Whitham, personal communication 1996). 
Sequence P2, Upper Bajocian (Figs 6, 35-37A, 39)

Ammonite evidence indicates that P2 spans the Upper Bajocian C. indistinctus and C.pompeckji Chronozones (Callomon 1993). Unpublished ${ }^{87} \mathrm{Sr} /{ }^{86} \mathrm{Sr}$ data obtained from belemnites also indicate a Late Bajocian age, by comparison with the strontium isotope curve of Jones et al. (1994).

\section{P2: Basal sequence boundary, SB2, and lowstand systems tract}

The basal sequence boundary, SB2, is developed as a distinct surface at localities 3 and 4 , and separates the C. borealis and C. indistinctus Chronozones. At localities 1 and 2, SB2 is a correlative conformity (Figs 35, 37A). In northern Jameson Land, SB2 coincides with a transgressive surface of erosion (TSE), and is commonly overlain by a transgressive lag. At localities 3 and 4, SB2 is overlain by shallow marine fine-grained sandstones, followed by medium- to coarse-grained marine clinoform-bedded sandstones, in all 35-40 m thick. The sandstones are interpreted as a lowstand systems tract, spanning the $C$. indistinctus and lowermost C. pompeckji Chronozones (Figs 6, 27, 37A). The deposits form the Ugleelv Member at localities 3 and 4. A distinct transgressive surface of erosion caps the systems tract, and passes northwards into SB2/TSE (Fig. 35). The hiatus corresponding to SB2 in northern Jameson Land is documented at localities 6 and $6 \mathrm{~A}$, where P1 contains the $C$. borealis $\beta$ fauna in the uppermost part, directly overlain by the C. carlsbergensis fauna of the C.pompeckji Chronozone (Callomon 1993), occurring in the basal transgressive lag of P2 (Figs 27, 37A). SB2 thus spans the $C$. indistinctus and lowermost C. pompeckji Chronozones in this area. The lowstand systems tract thins out rapidly just east of locality 3 and a few kilometres southeast of locality 4 . The termination in other directions is not exposed. The sandstone volume in the wedge is estimated at approximately $1.4 \mathrm{~km}^{3} / \mathrm{km}$ width, in an E-W section. The complete width is not known, but is estimated to be $60-80 \mathrm{~km}$, giving a total sandstone volume in the range of $84-112 \mathrm{~km}^{3}$ (Fig. 36).

\section{P2: Transgressive systems tract}

The lowstand systems tract at localities 3 and 4, and SB2 in northern Jameson Land, are capped by a transgressive surface of erosion (TSE), which passes into a simple flooding surface in southern Jameson Land. The TSE may be present on southern Traill $\varnothing$, as a marine ero- sional surface overlain by the ammonite $C$. gracilis (A.G. Whitham, personal communication 1995). The TSE is overlain by large numbers of $C$. carlsbergensis at localities 6, 6A, 11-14. The occurrence of the C. gracilis fauna on the surface at localities 3 and 4 , and of the slightly younger $C$. carlsbergensis fauna further north (except possibly in the Traill $\varnothing$ region), may reflect diachronous onset of sedimentation on this surface. The surface was formed by erosional retreat of the shoreface depositional system over more than $200 \mathrm{~km}$, from south of locality 5 to somewhere in the Traill $\varnothing-$ Geographical Society $\varnothing$ area, before the onset of renewed shoreline progradation, which ended at least $50 \mathrm{~km}$ north of the toe of the underlying lowstand systems tract of P2 (Figs 35, 37A). The TSE is overlain by a transgressive lag followed by thin offshore siltstones from locality 5 and northwards. It is directly overlain by offshore calcareous siltstones at localities 3 and 4 . The total volume of the sandstone part of the transgressive systems tract is broadly estimated to equal the sandstone volume of the preceding highstand systems tract, in the range of $1600-1900 \mathrm{~km}^{3}$ (Fig. 36).

\section{P2: Highstand systems tract}

The highstand systems tract of $\mathrm{P} 2$ is wedge-shaped and belongs to the upper part of the C. pompeckji Chronozone. It is up to $90 \mathrm{~m}$ thick in northern and central Jameson Land, and thins to less than $5 \mathrm{~m}$ in southern Jameson Land. It consists of four to five stacked simple sequences (Figs 35, 39), which form an aggradational to forwards-stepping sequence set (Fig. 35). In northern Jameson Land, the upper four sequences are generally amalgamated, with very minor or no offshore or lower shoreface deposits, suggesting a low rate of creation of new accommodation space. All sequences prograded to a position south of locality 5 . The C.episcopalis fauna is found in the middle to upper part of the systems tract throughout northern Jameson Land (Fig. $37 \mathrm{~A})$. The sandstone volume of the systems tract is in the range of $700-900 \mathrm{~km}^{3}$ in Jameson Land. The total sandstone volume, including deposits in the northernmost part of the basin is estimated at $1200-1400 \mathrm{~km}^{3}$, using the same assumption as for P1 (Fig. 36).

Sequence P3, Lower Bathonian (Figs 6, 36, 37B, 39) Ammonite evidence suggests that P3 is of Early Bathonian age. Unpublished ${ }^{87} \mathrm{Sr} /{ }^{86} \mathrm{Sr}$ values from belemnites suggest an Early-Middle Bathonian age, by comparison with the strontium isotope curve of Jones et al. 


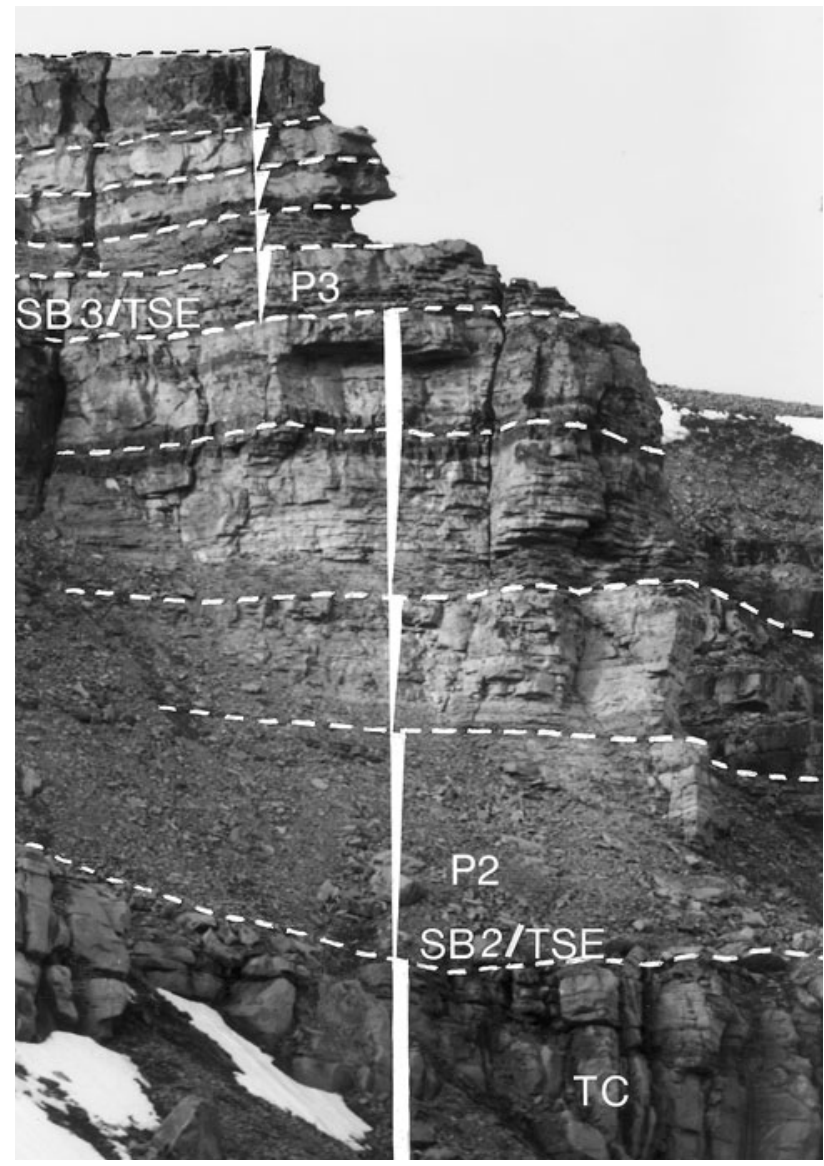

Fig. 39. Stacked shoreface and shallow, near-shore sand sheet units of $\mathbf{P 2}$ and $\mathbf{P 3}$ (Fig. 6). SB2/TSE and SB3/TSE are sequence boundaries, each coinciding with a transgressive surface of erosion, capping sequences $\mathrm{P} 1$ and $\mathrm{P} 2$, respectively, throughout northern Jameson Land. Tidal inlet channel sandstones (TC) of sequence P1 are seen in the lower part of the section. Sequence P2 is $90 \mathrm{~m}$ thick and consists of four shoreface units; sequence $\mathrm{P} 3$ is dominated by sand sheet deposits. The dark bands are horizons cemented with ankerite, dolomite, calcite and siderite. Pelion Formation, locality 7 (Fig. 2).

(1994). P3 contains the Arctocephalites arcticus fauna of the A. arcticus Chronozone throughout the study area. In south Jameson Land, the species $A$. delicatus of this zone is also found.

\section{SB3: Basal sequence boundary and lowstand systems tract}

The boundary between the C.pompeckji and the $A$. arcticus Chronozones coincides with a third order sequence boundary, SB3 (Fig. 37B). SB3 coalesces with a TSE from locality 5 and northwards. At locality 8, SB3 is interpreted locally to form the base of a minor incised valley, filled with estuarine deposits. SB3 passes into a correlative conformity within offshore deposits of the Fossilbjerget Formation south of locality 5, and marks a major shift in the lateral distribution of accommodation space at a composite sequence level. The depocentre of P3 is located in northern Jameson Land, and the thickness of $\mathrm{P} 3$ decreases both southwards and northwards of the depocentre (Fig. 37B). This contrasts with the underlying P2, which shows a tabular geometry throughout the northern localities southwards to locality 5 , south of which it thins rapidly.

A single occurrence of estuarine deposits (locality 8), positioned immediately above $\mathrm{SB} 3$, is interpreted to form part of the lowstand systems tract. Lowstand deposits may have existed between localities 4 and 5 , but if so, they have been removed by recent erosion.

\section{P3: Transgressive systems tract}

The transgressive systems tract is represented by a TSE overlain by lag deposits, which may be followed by thin, calcareous siltstones interpreted to have been deposited during maximum flooding. The upper part of the estuarine association of locality 8 may also belong to the transgressive systems tract. The total volume of the sandstone part of the transgressive systems tract is estimated at $1200-1400 \mathrm{~km}^{3}$, using the same assumptions as for P2 (Fig. 36).

\section{P3: Highstand systems tract}

The highstand systems tract volumetrically dominates P3 throughout central and northern Jameson Land. It is 42 $\mathrm{m}$ thick at locality 11 , thickens to $50-60 \mathrm{~m}$ at locality 8 (the thickness is approximate, due to limited stratigraphic control), and thins to less than $15 \mathrm{~m}$ at locality 5 . Sequence P3 is not clearly distinguishable in southern Jameson Land, but the stratigraphic interval corresponding to the sequence covers less than $8 \mathrm{~m}$ at localities 3 and 4 . At localities 5 and 8 , only the uppermost part of $\mathrm{P} 3$ is represented by shoreface deposits, whereas the lower part consists of offshore siltstones and fine-grained sandstones, reflecting the forwards-stepping nature of the sequence set (Fig. 37B). During highstand time, shoreface units stepped forwards over more than $30 \mathrm{~km}$. The highstand systems tract is capped by a low order sequence boundary, SB4, which is developed as an unconformity and coincides with a transgressive surface of erosion from central Jameson Land and further north (Fig. 37B). The sandstone volume of the systems tract 
in Jameson Land is in the range of $400-500 \mathrm{~km}^{3}$, and the total volume of the sandstone part is estimated at 900-1000 $\mathrm{km}^{3}$, using the same assumptions as for P1 (Fig. 36).

A carbonate-cemented, fossiliferous, fully marine sandstone, c. $30 \mathrm{~m}$ thick, covers the stratigraphic level of $\mathrm{P} 2$ and $\mathrm{P} 3$ on northern Geographical Society $\varnothing$. The unit is overlain by deposits containing A. micrumbilicatus and is interpreted as a tidal channel fill overlain by transgressive sand sheet deposits (A.G. Whitham, personal communication 1996).

\section{Sequence P4, Lower-Middle Bathonian}

(Figs 6, 36, 37B, 38B)

Ammonite evidence indicates an Early-Middle Bathonian age for sequence $\mathrm{P} 4$. Unpublished ${ }^{87} \mathrm{Sr} /{ }^{86} \mathrm{Sr}$ values from belemnites also suggest an Early to Middle Bathonian age, by comparison with the strontium isotope curve of Jones et al. (1994). P4 contains the A. micrumbilicatus and $A$. greenlandicus faunas of the $A$. greenlandicus Chronozone in the lower part, and $A$. harlandi and the A. ishmae $\alpha$ faunas of the A. ishmae Chronozone in the upper part of the sequence. The $A$. ishmae fauna is also found on Traill $\varnothing$.

\section{SB4: Basal sequence boundary}

The upper boundary of $\mathrm{P} 3$ is formed by a low order sequence boundary, SB4, which coincides with a TSE from locality 5 and northwards, except at a position between localities 10 and 11, where it locally forms the base of an incised channel fill, up to $30 \mathrm{~m}$ thick, capped by the TSE (Fig. 37B). South of locality 5, SB4 is developed as a correlative conformity, and the transgressive surface of erosion passes into a simple marine flooding surface.

It is suggested that the hiatus associated with SB4 covers the uppermost $A$. arcticus Chronozone in northern Jameson Land, separating the $A$. arcticus fauna of the $A$. arcticus Chronozone and the $A$. micrumbilicatus fauna of the $A$. greenlandicus Chronozone; the $A$. delicatus fauna of the $A$. arcticus Chronozone is absent. A. delicatus is only found in southern Jameson Land, where it occurs in the basal part of P4. At locality 5, an uncertain occurrence of this species is indicated, but this might instead be a specimen of $A$. arcticus (Callomon 1993). In any event, a considerable faunal hiatus is thought to separate the $A$. arcticus and A. delicatus faunas of the A. arcticus Chronozone in East Greenland.
The missing interval may be represented by the $A$. spathi, A. porcupinensis and $A$. arcticus faunas in part of the A. spathi and A.porcupinensis Chronozones known from the Yukon area, Canada (Callomon 1993). Lowstand systems tract deposits have not been identified in P4. Deposits of this systems tract may have been deposited in the area between localities 4 and 5 but, if so, have been removed by recent erosion.

\section{P4: Transgressive systems tract}

A significant transgression is interpreted to have occurred after SB4 time, leaving a transgressive lag throughout northern Jameson Land, and possibly further north. This lag is overlain by a thin sheet of offshore siltstones, locally rich in bivalves, belemnites and ammonites, interpreted as a condensed unit and representing the level of maximum flooding. The transgressive lag and the condensed offshore deposits contain the A. micrumbilicatus fauna of the lower $A$. greenlandicus Chronozone throughout Jameson Land, whereas the $A$. delicatus fauna is restricted to southern Jameson Land. The lower faunas of the A. greenlandicus Chronozone are found throughout Jameson Land. The volume of the sandstone part of the transgressive systems tract is estimated to be in the order of $900-1000 \mathrm{~km}^{3}$, including sandy deposits in the Traill $\varnothing$ - Geographical Society $\varnothing$ area, using previous assumptions (Fig. 36).

\section{P4: Highstand systems tract}

The highstand systems tract of $\mathrm{P} 4$ contains ammonites of the middle to upper $A$. greenlandicus and $A$. ishmae Zones (A. greenlandicus, A. freboldi, A. harlandi and $A$. ishmae $\alpha$ faunas). Sequence $\mathrm{P} 4$ is $c .60 \mathrm{~m}$ thick throughout northern and central Jameson Land, and is volumetrically dominated by a forwards-stepping set of simple sequences, P4A-D (Fig. 37B).

The thickness of the section which covers the stratigraphic interval of P2-4 on Geographical Society $\varnothing$ is only $30 \mathrm{~m}$ (A.G. Whitham, personal communication 1995), compared to $250 \mathrm{~m}$ in north Jameson Land. This large difference is interpreted to be the result of a high degree of sedimentary bypass and erosion in the northern, proximal areas during times of falling sea level and lowstand. The sandstone volume of the systems tract in Jameson Land is in the order of $700-800 \mathrm{~km}^{3}$; the total sandstone volume is estimated at $900-1000 \mathrm{~km}^{3}$ (Fig. 36). 
Sequence P5, Middle-Upper Bathonian

(Figs 6, 36, 37B)

Sequence $\mathrm{P} 5$ is up to $75 \mathrm{~m}$ thick, and consists of an aggradational sequence set (P5A-E). The maximum southwards progradation distance of $\mathrm{P} 5$ is $c .25 \mathrm{~km}$ less than that of the underlying P4, marking the onset of the large-scale backstepping pattern of the composite sequences from P5 to P8 (Figs 6, 37B; Surlyk 1990b, 1991). $\mathrm{P} 5$ spans the upper $A$. ishmae, A. cranocephaloide, C. variabile and C. calyx Chronozones indicating a Middle to Late Bathonian age-span for the sequence (Figs 6, 37B). Unpublished ${ }^{87} \mathrm{Sr} /{ }^{86} \mathrm{Sr}$ values from belemnites also indicate a Middle to Late Bathonian age, by comparison with the strontium isotope curve of Jones et al. (1994).

The $A$. ishmae $\beta$ fauna of the $A$. ishmae Chronozone is one of the most common and widespread faunas in the Arctic. It occurs throughout Jameson Land, and has also been found on Traill $\varnothing$ (Donovan 1953). At this level, the genus Oxycerites occurs; it is usually restricted to lower latitudes in the Tethyan Realm, and indicates a Late Bathonian age (Birkelund et al. 1971). The presence of Oxycerites suggests that the transgression that ended deposition of $\mathrm{P} 4$ was linked to a eustatic rise in sea level, permitting migration of ammonites between the Boreal and Tethyan Realms.

\section{SB5: Basal sequence boundary}

SB5 is positioned in the A. ishmae Chronozone, separating the $A$. ishmae $\alpha$ and $\beta$ faunas. SB5 is developed as an SB/TSE in central Jameson Land (Fig. 2, locality 5) and further north. In central Jameson Land, SB5 tops the uppermost shoreface deposits of the Pelion Formation, and is overlain by offshore siltstones of the Fossilbjerget Formation. In northern Jameson Land, SB5 separates condensed sequences of $\mathrm{P} 4$ from the less condensed sequences of P5. Lowstand systems tract deposits have not been identified in P5, but may have existed in the area between localities 5 and 8, and if so, have been removed by recent erosion.

\section{P5: Transgressive systems tract}

The transgressive systems tract deposits are generally thin. In southern Jameson Land, the tract is represented by a marine flooding surface overlain by thin offshore siltstones, interpreted as a condensed unit. From locality 5 and northwards, it is represented by a transgressive surface of erosion, locally overlain by a conglomerate lag or sandstone sheet, up to $4 \mathrm{~m}$ thick, with abundant A. ishmae $\beta$. These deposits are overlain by thin, laminated offshore siltstones, interpreted to represent the level of maximum flooding. The total volume of the sandstone part of the transgressive systems tract is estimated at $900-1000 \mathrm{~km}^{3}$ (Fig. 36).

\section{P5: Highstand systems tract}

The highstand systems tract of P5 contains Arcticoceras crassiplicatum of the $A$. ishmae Chronozone, and $A$. cranocephaloide, Kepplerites tychonis, K. rosenkrantzi, $K$. peramplus, K. vardekloeftensis and K. svalbardensis of the A. cranocephaloide, C. variabile and C. calyx Chronozones. In northern Jameson Land, the highstand systems tract of P5 is dominated by progradational shoreface units. The shorelines prograded southwards, at least as far south as locality 8 (Fig. 37B). At this locality, P5 consists of more than three coarsening-upwards offshore units of the Fossilbjerget Formation. At locality 5 , the upper part of $\mathrm{P} 5$ contains $K$. peramplus and $K$. svalbardensis of the C. calyx Chronozone. In southern Jameson Land, the C. calyx Chronozone marks the onset of a significant increase in the degree of condensation of the offshore deposits of the Fossilbjerget Formation (Surlyk et al. 1973; Callomon 1993). The sandstone volume of the systems tract in Jameson Land is in the order of $400-500 \mathrm{~km}^{3}$, and the total sandstone volume is estimated at $700-800 \mathrm{~km}^{3}$ (Fig. 36). Sandy, shallow marine deposits of the transgressive systems tract exist in the Traill $\varnothing$ - Geographical Society $\varnothing$ area, corresponding to the level of $\mathrm{P} 5$, although a precise biostratigraphic correlation has not yet been made.

\section{Sequence P6, Upper Bathonian - Lower Callovian} (Figs 6, 36, 37B)

The composite sequence P6 spans the C. apertum and C. nordenskjoeldi Chronozones. The duration of $\mathrm{P} 6$ is about $1.5 \mathrm{Ma}$, according to the time-scale of Gradstein et al. (1994; Fig. 6). P6 is backstepping in the lower part and forestepping in the upper part. It has only been studied in detail at locality $9 \mathrm{~A}$.

\section{SB6: Basal sequence boundary}

SB6 coincides with a transgressive surface of erosion throughout northern Jameson Land. In this area, the hiatus at SB6 corresponds to the K. vardekloeftensis faunal horizon of the C. calyx Chronozone, and this fauna 
is restricted to southern Jameson Land (Fig. 37B; Callomon 1993). The C. apertum $\alpha$ fauna of the C. apertum Chronozone is found immediately above SB6. At this stratigraphic level, biostratigraphic correlation with European ammonite faunas is again possible, and the C. apertum Chronozone correlates with the C. discus and part of the $M$. herveyi Chronozones (Callomon 1993). SB6 is situated close to the base of the Callovian in East Greenland, and forms a very prominent correlation surface throughout central and northern Jameson Land. A major northwards retreat of the depositional systems is recorded across the SB6/TSE (Fig. 6). Lowstand systems tract deposits have not been identified in sequence P6; if deposited, they are expected to occur south of locality 8 .

In southern Jameson Land, P6 is represented by offshore siltstones, which form part of a condensed unit that spans most of the Lower Callovian (Figs 6, 37B; Surlyk et al. 1973; Birkelund 1975; Surlyk 1990b, 1991; Callomon 1993). The distal condensation reflects the overall large-scale backstepping of the third order sequences during this time interval.

\section{P6: Transgressive systems tract}

At locality 9A, the transgressive systems tract consists of a basal lag, overlain by offshore siltstones and very fine-grained sandstones, $22 \mathrm{~m}$ thick (level 1-23 $\mathrm{m}$ in Fig. 33). The deposits include a transgressive sand sheet, $5 \mathrm{~m}$ thick, overlain by a shoreface unit, $5 \mathrm{~m}$ thick, which is followed by an overall backstepping set of shallow offshore, storm-influenced coarsening-upwards units, each 1-1.5 $\mathrm{m}$ thick, representing the distal edges of shoreface units. At localities 8 and 11, similar deposits are found at the same stratigraphic level, and are interpreted as belonging to the transgressive systems tract. The total volume of the sandstone part of the transgressive systems tract is estimated at $700-800 \mathrm{~km}^{3}$, including sandy deposits in the Traill $\varnothing$ - Geographical Society $\varnothing$ area (Fig. 36).

\section{P6: Highstand systems tract}

At locality 9A, a change in stacking pattern, and the reappearance of shallow water sandstones in the section, marks the transition from the transgressive to the highstand systems tract. At locality 9A, the highstand systems tract of $\mathrm{P} 6$ is $31 \mathrm{~m}$ thick and consists of coarseningupwards offshore and shoreface units, separated by non-erosional or erosional marine flooding surfaces (23-54 $\mathrm{m}$ in Fig. 33). The units are stacked in a forwards- stepping pattern. The uppermost three units show intense burrowing by Diplocraterion habichi, Monocraterion tentaculatum, Ophiomorpha nodosa and Skolithos isp., suggesting very shallow water depths. A shallow water depth is also indicated by the occurrence of both small and large wave-ripples as well as swaley cross-stratification. The package comprising the three coarsening-upwards units forms the 'minor regressive cycle' of Heinberg \& Birkelund (1984); this unit forms the Parnas Member of the Pelion Formation (Surlyk 2003, this volume, fig. 5). The deposits are interpreted as near-shore sand sheet and shoreface units. In northernmost Jameson Land, P6 consists of shoreface deposits only. The sandstone volume of the systems tract in Jameson Land is estimated at $200-300 \mathrm{~km}^{3}$, and the total sandstone volume is estimated at $400-500 \mathrm{~km}^{3}$ (Fig. 36).

Sequences P7 and P8, Lower-Upper Callovian (Figs 6, 36, 37B, 38C)

Sequence P7 covers the K. koenigi Chronozone, with a duration of about $1 \mathrm{Ma}$, and sequence P8 covers the S. calloviense, K. jason, E. coronatum and lower P. athleta Chronozones, with a total duration of about $2.5 \mathrm{Ma}$, according to the time-scale of Gradstein et al. (1994).

\section{SB7: Basal sequence boundary}

SB7 occurs near the boundary between the C. nordenskjoeldi and K. koenigi Chronozones. It marks the maximum progradation of highstand deposits of $\mathrm{P} 6$, which form the Parnas Member. In northern Jameson Land, SB7 is developed as an SB/TSE, whereas it is represented by a correlative conformity in central and southern Jameson Land.

\section{The deposits of P7 and P8, Lower-Upper Callovian}

The deposits of P7 and P8 are not subdivided into systems tracts, due to a lack of distinct depositional trends. The sequences form the uppermost part of the Pelion-Fossilbjerget couplet. Throughout south and central Jameson Land, the sequences are represented by offshore siltstones of the Fossilbjerget Formation, grading into shoreface sandstones of the Pelion Formation in northern Jameson Land (Fig. 37B).

A minor progradational unit, 3-4 $\mathrm{m}$ thick, is dated to the upper K. koenigi - lower $S$. calloviense Chronozones. It contains the $K$. galilaeii and $S$. calloviense 
faunas (Birkelund et al. 1971). In this unit, two sandstone sheets, together up to $3 \mathrm{~m}$ thick, separated by bioturbated siltstones, were deposited in the otherwise siltstone-dominated offshore environment (Fig. 37B, localities 9A, 11). The sandstone beds show hummocky cross-stratification, and Ophiomorpha nodosa burrows, which also occur in the interbedded siltstones. A rich fauna of ammonites, belemnites, bivalves, gastropods and brachiopods occurs in the beds. The trace fossils suggest a nearshore position, and the sandstone beds are interpreted as nearshore storm deposits, laid down above storm wave base. The upper bed is topped by a marine flooding surface, overlain by parallel, even laminated, offshore mudstones. The sandstones are interpreted as the basinwards limit of a forwards-stepping depositional unit, possibly forming the distal edge of lowstand deposits of P8. The top of the sandstones mark the Lower-Middle Callovian boundary in the area. Throughout Jameson Land, P8 forms an important condensed level, which caps the Pelion and Fossilbjerget Formations in the area, and which is downlapped by the Olympen Formation (Figs 6, 37B). In northern Jameson Land, shallow marine sandstones of the Pelion Formation correspond to the stratigraphic interval of P7 and P8 (Surlyk et al. 1973; Heinberg \& Birkelund 1984). Condensation in south Jameson Land was initiated in P5 time, and in the upper part includes the Middle Callovian offshore Goniomyakløft Member of the Fossilbjerget Formation (Surlyk 2003, this volume, fig. 5), the 'wood beds' of Callomon (1993) containing Kosmoceras cf. or aff. jason of the K. jason Chronozone (Callomon 1961, 1993; Surlyk \& Birkelund 1972; Surlyk et al. 1973, 1993; Surlyk 1990b, 1991). In central Jameson Land, Longaeviceras keyserlingi of the P. athleta Chronozone occurs c. $20 \mathrm{~m}$ below the Fossilbjerget Formation Olympen Formation boundary (Larsen \& Surlyk 2003, this volume). In northern Jameson land, a single specimen of Kosmoceras (Zugokosmokeras) cf. phaeinum (Buchman) or Kosmoceras (Zugokosmokeras) cf. proniae (Teisseyre) of the P. atbleta Chronozone was found $2.8 \mathrm{~m}$ below the boundary. A fragment of Kosmoceras (Zugokosmokeras) cf. proniae was reported from $15 \mathrm{~m}$ above the boundary in north-west Jameson Land (Birkelund et al. 1971). The Goniomyakløft Member in southern Jameson Land thus represents the top of the Pelion-Fossilbjerget couplet and possibly overlaps with the basal part of the Olympen Formation to the north.

The faunas of the $P$. atbleta Chronozone represent a mixture of a true Boreal fauna, with Longaeviceras, and a sub-Boreal Kosmoceras fauna (Callomon 1993). This faunal mixing strongly suggests that the long term transgression, recorded from $\mathrm{P} 5$ to $\mathrm{P} 8$, was eustatic in origin. In southern Jameson Land, the Goniomyakløft Member is overlain by thin shales of the Hades Member (Olympen Formation) or by the shales and massive sandstones of the Upper Oxfordian - Lower Volgian Hareelv Formation (Fig. 6; Surlyk \& Birkelund 1972; Surlyk et al. 1973; Surlyk 1987, 1991, 2003, this volume; Callomon 1993; Surlyk \& Noe-Nygaard 2001b).

\section{Regional implications}

The couplet comprising the Pelion and Fossilbjerget Formations forms the lower half of a large-scale Middle Jurassic regressive-transgressive-regressive succession, and is approximately time-equivalent with the Brent Group of the Northern North Sea and with the Krossfjord and Fensfjord Formations and to some extent the Garn Formation on the Norwegian shelf. The depositional pattern of the Brent Group has been related to the uplift and subsequent deflation of a major volcanic dome (Sellwood \& Hallam 1974; Whiteman et al. 1975; Hallam \& Sellwood 1976; Ziegler 1988, 1990; Underhill \& Partington 1993, 1994). The presence of a similar, roughly contemporaneous regional Early Jurassic uplift and subsequent subsidence in East Greenland was suggested by Surlyk (1977a, 1978) and Surlyk et al. (1993) on stratigraphical grounds and corroborated by fission track thermochronology by Johnson \& Gallagher (2000). The main East Greenland uplift was centred in northern East Greenland, and the eastern part of the uplift area is today probably located on the Norwegian shelf off Lofoten. Uplift of the East Greenland area probably commenced in the Early Jurassic, culminating in Toarcian-Aalenian times. The regional uplift is probably partly equivalent to the uplifted intra-rift area between Greenland and Norway of Doré (1991; Fig. 5).

Rifting began in the Late Bajocian, increased during the Bathonian-Kimmeridgian and culminated in Kimmeridgian - mid-Volgian times (Surlyk et al. 1981). Sequence P1 and the lower part of P2 of the Pelion and Fossilbjerget Formations show the development of shallow marine sandstones of Late Bajocian - Early Bathonian age in a basinal position, which are similar to time-equivalent deposits in the Northern North Sea and the Norwegian shelf described, for example, by Gjelberg et al. (1987), Helland-Hansen et al. (1992) and Mitchener et al. (1992). Major flooding events occurred both in the North Sea area and in Jameson Land near the Bajocian-Bathonian boundary, indicating the onset of an inter-regional transgression (Surlyk et al. 1973, 1981, 
1993; Birkelund 1975; Surlyk 1990a, b, 1991, 2003, this volume; Helland-Hansen et al. 1992; Mitchener et al. 1992; Steel 1993). The P3 and P4 sequences show a largescale progradational stacking pattern. SB5 at the base of P5 coincides with the lithostratigraphic top of the Pelion Formation in central Jameson Land, and marks a major shift from shoreface to offshore depositional environments. SB6 at the top of P5 roughly coincides with the Bathonian-Callovian boundary in Jameson Land, and forms the top of the Pelion Formation throughout northern Jameson Land, marking a major landwards shift in depositional environments. The P5-8 sequences show a large-scale backstepping pattern. The distance of overall large-scale shoreline backstepping from P1 to P5 is more than $100 \mathrm{~km}$. Backstepping through P6-8 is about $50 \mathrm{~km}$. In northern central Jameson Land, only the upper part of P8 forms part of the condensed succession, which in south Jameson Land covers most of the Callovian, and marks the culmination of backstepping (Surlyk 1977b, 1990b, 1991, 2003, this volume; Surlyk et al. 1993; Alsen \& Surlyk in press). Throughout central East Greenland, the condensed unit is characterised by a mixture of true Boreal and sub-Boreal ammonite faunas (Callomon 1993), supporting the sequence stratigraphic interpretation of the inter-regional character of the large-scale transgression. The transgression, which was initiated in the Late Bathonian (P5), and continued into the Early Oxfordian, was partly of eustatic origin according to Hallam (1988). Domal subsidence may also have caused a significant relative sea-level rise through this time span in the areas influenced by the domes, similar to the situation in the North Sea (for further discussion, see Surlyk 1990b, Surlyk et al. 1993 and Underhill \& Partington 1994).

\section{Summary}

In Middle Jurassic times, a north-south elongate shallow marine embayment was formed in central East Greenland with a low gradient, without a marked shelfslope break. Throughout the East Greenland basin, the base of the Pelion Formation marks the onset of a new depositional cycle characterised by a major re-arrangement of drainage patterns, extensive transgressive onlap and the influx of large amounts of quartzose sand, interpreted as reflecting the onset of the important MiddleLate Jurassic rift phase which culminated in Kimmeridgian-Volgian times (Surlyk 1978, 1990a, b, 2003, this volume; Surlyk \& Clemmensen 1983; Surlyk \& NoeNygaard 2000). The low axial gradient of the basin- floor resulted in the development of laterally extensive simple sequences, formed by predominantly axial shoreline progradation. The distribution and architecture of the sandstone units were controlled by changes in relative sea level. A total of 28 simple sequences are recognised. Detailed biostratigraphic correlations at the level of ammonite zones and faunal horizons show that the average duration of a simple sequence is about 360,000 years. They are the smallest-scale units which can be correlated over large distances and they are bounded by laterally extensive key surfaces. Of special importance for the sequence stratigraphic interpretation is the nature of transgressive marine lags, which form the basal deposits of most sequences. The presence of laterally widespread pebble lags, containing intra- and extra-formational clasts, mainly of larger sizes than those present in the underlying deposits, is interpreted to indicate that a modified sequence boundary coincides with the base of the lag deposits (Surlyk et al. 1993, 1995). The horizontal distribution of transgressive lag conglomerates directly reflects the original distribution of the former presence of foreshore, beach, and fluvial deposits.

The very extensive lateral distribution of the shallow marine sandstones of the Pelion Formation, over more than $20,000 \mathrm{~km}^{2}$, and the distribution of coarse pebbly sandstones and conglomerates over more than 10,000 $\mathrm{km}^{2}$ indicate that major rivers continuously delivered coarse-grained sediments to the southwards prograding shorelines. The rivers entered the basin at its northern and western margin at relay zones between en echelon right-stepping border faults, as testified by palaeocurrent data and the large-scale textural and facies distribution (Surlyk et al. 1973, 1981; Surlyk 1977b, 1990a; Surlyk \& Clemmensen 1983). The proportion of conglomerates and coarse-grained sandstones decreases southwards, indicating that the transport capacity of the rivers decreased as the floodplain became wider during progradation. Only one localised occurrence of terrestrial deposits is recognised in Jameson Land. This is most likely a consequence of transgressive marine erosion of floodplain, lagoonal and fluvial sediments of the underlying sequences.

The sequences generally consist of a thin transgressive systems tract, dominated by a sandstone or pebble lag overlain by fossiliferous, calcareous siltstones or mudstones representing a condensed unit, followed by sandy highstand, forced regressive and lowstand deposits (Fig. 34). Detached lowstand shoreface deposits were probably not developed during the high-order cycles because of a continuous, high sediment influx 
to the basin and a high sediment distribution rate. In proximal areas, the sequences are terminated upwards by coincident sequence boundaries and transgressive surfaces of erosion. In distal offshore areas, the correlative conformities are difficult to pinpoint.

Definition of low-order composite sequences is based on the stacking pattern of the high-order sequences, the nature and extent of marine transgressive lags, and a detailed biostratigraphical ammonite zonation based on faunal horizons. Eight composite sequences are recognised (P1-8), each with a duration of 1-2.5 Ma (Fig. 6). In proximal realms, the sequences are separated by subaerial erosion surfaces representing sequence boundaries, coincident with marine transgressive surfaces of erosion. More distally, the sequence boundaries are represented by surfaces marking significant basinwards shift in facies (Fig. 35). Low-order sequence boundaries mark major changes in the overall stacking pattern of the high-order sequences.

The composite sequences are subdivided into systems tracts, which in the study area are highly asymmetric, volumetrically dominated by highstand deposits (Fig. 35). These consist of aggradational to forwardsstepping sequence sets, generally made up of thin offshore siltstones overlain by progradational shoreface and shallow marine, near-shore sandstones and conglomerates, deposited in response to high-order sea-level fall (forced regressions) and lowstand. The sandy deposits of the low-order highstand systems tract downlap onto extensive condensed offshore deposits, deposited during maximum flooding. Two examples of low-order lowstand sandstones are documented, belonging to P1 and $\mathrm{P} 2$, while a third, belonging to $\mathrm{P} 8$, is less well documented (Figs 35, 36). In the northern part of the study area, the transgressive systems tracts are mostly represented by a transgressive surface of erosion, commonly overlain by a thin coarse-grained sandstone or pebble lag or a thin sand sheet. A thicker transgressive systems tract has only been identified in P1, at localities 3 and 4, and in P6 at locality 9 in northern central Jameson Land. In each sequence, the transgressive systems tract consists of backstepping offshore to shoreface depositional units, reflecting fluctuations in relative sea level on a higher order scale (Fig. 33). Volumetrically large portions of P7 and P8 may also form part of transgressive systems tracts throughout north-central Jameson Land, but this has not been quantified due to lack of clear depositional trends. Distally, in southern Jameson Land, the transgressive systems tracts are represented by simple marine flooding surfaces, overlain by condensed offshore deposits. The volumetric distribution of the sandy parts of the low-order systems tracts are quantified based on values obtained from the study area and unpublished data from the Traill $\varnothing-$ Geographical Society $\varnothing$ area.

\section{Acknowledgements}

This study is based on field work in Jameson Land, East Greenland during the summers of 1991 to 1995 , generously supported by Norsk Hydro A/S, Research Centre, Bergen. John Gjelberg is especially thanked for interest, support and discussion. M.E. gratefully acknowledges the Carlsberg Foundation (ANS. 94-0204/20) for support during the preparation of this paper. The Danish Natural Science Research Council is acknowledged for support during the last phase of field work. John H. Callomon is thanked for determinations of the ammonites collected by the authors, for providing much new material, and for discussion of the biostratigraphy. René Madsen is thanked for drafting, Ole Bang Berthelsen for photography and $\mathrm{M}$. Vesterager for word processing. Snorre Olaussen, John Gjelberg and Jon R. Ineson contributed with much appreciated, highly constructive reviews.

\section{References}

Allen, G.P. 1991: Sedimentary processes and facies in the Gironde estuary: a recent model of macrotidal estuarine systems. In: Smith, G.D. et al. (eds): Clastic tidal sedimentology. Canadian Society of Petroleum Geologists Memoir 16, 29-39.

Allen, J.R.L. 1965: Late Quaternary Niger Delta, and adjacent areas: sedimentary environments and lithofacies. American Association of Petroleum Geologists Bulletin 49, 547-600.

Alsen, P. \& Surlyk, F. in press: Maximum Middle Jurassic transgression in East Greenland: evidence from new ammonite finds, Bjørnedal, Traill Ø. In: Stemmerik, L. \& Stouge, S. (eds): The Jurassic of North-East Greenland. Geological Survey of Denmark and Greenland Bulletin.

Alsgaard, P.C., Felt, V.L., Vosgerau, H. \& Surlyk, F. 2003: The Jurassic of Kuhn $\varnothing$, North-East Greenland. In: Ineson, J.R. \& Surlyk, F. (eds): The Jurassic of Denmark and Greenland. Geological Survey of Denmark and Greenland Bulletin 1, 865-892 (this volume).

Barwis, J.H. 1985: Tubes of the modern Polychaete Diopatra cuprea as current velocity indicators and as analogs for Skolithos-Monocraterion. In: Curran, H.A. (ed.): Biogenic structures: their use in interpreting depositional environments. Society of Economic Palaeontologists and Mineralogists Special Publication 35, 225-236.

Bhattacharya, J. \& Walker, R.G. 1991: River- and wave-dominated depositional systems of the Upper Cretaceous Dunvegan 
Formation, northwestern Alberta. Bulletin of Canadian Petroleum Geology 39, 165-191.

Birkelund, T. 1970: Field notes 1970, Kap Leslie-området, Jameson Land, $148 \mathrm{pp}$. Unpublished field diary, Geological Survey of Greenland, Copenhagen.

Birkelund, T. 1971: Field notes 1971, Jameson Land, 101 pp. Unpublished field diary, Geological Survey of Greenland, Copenhagen.

Birkelund, T. 1975: A review of the Jurassic of East Greenland. In: Finstad, K.G. \& Selley, R.C. (coordinators): Jurassic Northern North Sea Symposium, Stavanger, 28-30 September, 1975. Norwegian Petroleum Society (NPF) Proceedings JNNS/6, $1-27$.

Birkelund, T. \& Callomon, J.H. 1985: The Kimmeridgian ammonite faunas of Milne Land, central East Greenland. Bulletin Grønlands Geologiske Undersøgelse 153, 56 pp.

Birkelund, T. \& Heinberg, C. 1974: Field notes 1974, Jameson Land, 112 pp. Unpublished field diary, Geological Survey of Greenland, Copenhagen.

Birkelund, T. \& Perch-Nielsen, K. 1976: Late Palaeozoic - Mesozoic evolution of central East Greenland. In: Escher, A. \& Watt, W.S. (eds): Geology of Greenland, 304-339. Copenhagen: Geological Survey of Greenland.

Birkelund, T., Håkansson, E. \& Surlyk, F. 1971: New finds of Bathonian, Callovian and Oxfordian ammonites in northern Jameson Land, East Greenland. Bulletin of the Geological Society of Denmark 20, 240-259.

Birkelund, T., Callomon, J.H. \& Fürsich, F.T. 1984: The stratigraphy of the Upper Jurassic and Lower Cretaceous sediments of Milne Land, central East Greenland. Bulletin Grønlands Geologiske Undersøgelse 147, 56 pp.

Birkenmajer, K. 1976: Middle Jurassic nearshore sediments at Kap Hope, East Greenland. Bulletin of the Geological Society of Denmark 25, 107-116.

Boersma, J.R. \& Terwindt, J.H.J. 1981: Neap-spring tide sequences of intertidal shoal deposits in a mesotidal estuary. Sedimentology 28, 151-170.

Brenchley, P.J., Romano, M. \& Guiterrez, M.J.C. 1986: Proximal and distal hummocky cross-stratified facies on a wide Ordovician shelf in Iberia. In: Knight, R.J. \& McLean, J.R. (eds): Shelf sands and sandstones. Canadian Society of Petroleum Geologists Memoir 11, 241-256.

Brenchley, P.J., Pickerill, R.K. \& Stromberg, S.G. 1993: The role of wave reworking on the architecture of storm sandstone facies, Bell Island Group (Lower Ordovician), eastern Newfoundland. Sedimentology 40, 359-382.

Bromley, R.G. 1975: Trace fossils at omission surfaces. In: Frey, R.W. (ed.): The study of trace fossils, 399-428. New York: Springer Verlag.

Bromley, R.G. \& Asgaard, U. 1972: Notes on Greenland trace fossils. Rapport Grønlands Geologiske Undersøgelse 49, 30 pp.

Bromley, R.G., Bruun-Petersen, J. \& Perch-Nielsen, K. 1970: Preliminary results of mapping in the Palaeozoic and Mesozoic sediments of Scoresby Land and Jameson Land. Rapport Grønlands Geologiske Undersøgelse 30, 17-30.

Callomon, J.H. 1959: The ammonite zones of the Middle Jurassic beds of East Greenland. Geological Magazine 96, 505-513.
Callomon, J.H. 1961: The Jurassic System in East Greenland. In: Raasch, G.O. (ed.): Geology of the Arctic 1, 258-268. Toronto: Toronto University Press.

Callomon, J.H. 1970: Geological map of Carlsberg Fjord Fossilbjerget area. Meddelelser om Grønland 168(4), 1-9.

Callomon, J.H. 1972: Jurassic System. In: Callomon, J.H., Donovan, D.T. \& Trümpy, R. (eds): An annotated map of the Permian and Mesozoic formations of East Greenland. Meddelelser om Grønland 168(4), 15-21.

Callomon, J.H. 1993: The ammonite succession in the Middle Jurassic of East Greenland. Bulletin of the Geological Society of Denmark 40, 83-113.

Callomon, J.H. 1994: Jurassic ammonite biochronology of Greenland and the Arctic. Bulletin of the Geological Society of Denmark 41, 128-137.

Callomon, J.H. 2003: The Middle Jurassic of western and northern Europe: its subdivisions, geochronology and correlations. In: Ineson, J.R. \& Surlyk, F. (eds): The Jurassic of Denmark and Greenland. Geological Survey of Denmark and Greenland Bulletin 1, 61-73 (this volume)

Callomon, J.H. \& Birkelund, T. 1980: The Jurassic transgression and the mid-late Jurassic succession in Milne Land, central East Greenland. Geological Magazine 117, 211-226.

Campbell, C.V. \& Oaks, R.Q. 1973: Estuarine sandstone filling tidal scours, Lower Cretaceous Fall River Formation, Wyoming. Journal of Sedimentary Petrology 43, 765-778.

Cant, D.J. 1991: Geometric modelling of facies migration: theoretical development of facies successions and local unconformities. Basin Research 3, 51-62.

Carr, I.D. 1998: Facies analysis and reservoir characterisation of Jurassic sandstones from Bjørnedal, central East Greenland, 245 pp. Unpublished Ph.D. thesis, University of Reading, UK.

Clemmensen, L.B. 1980: Triassic rift sedimentation and palaeogeography of central East Greenland. Bulletin Grønlands Geologiske Undersøgelse 136, 72 pp.

Clifton, H.E. 1969: Beach lamination: nature and origin. Marine Geology 7, 553-559.

Clifton, H.E. 1976: Wave-formed sedimentary structures: a conceptual model. In: Davis, R.A. \& Ethington, R.L. (eds): Beach and nearshore sedimentation. Society of Economic Paleontologists and Mineralogists Special Publication 24, 126-148.

Clifton, H.E. 1983: Discrimination between subtidal and intertidal facies in Pleistocene deposits, Willapa Bay, Washington. Journal of Sedimentary Petrology 53, 353-369.

Clifton, H.E., Hunter, R.E. \& Phillips, R.L. 1971: Depositional structures and processes in the non-barred high-energy nearshore. Journal of Sedimentary Petrology 41, 651-670.

Cordey, W.G. 1993: Jurassic exploration history: a look at the past and the future. In: Parker, J.R. (ed.): Petroleum geology of Northwest Europe: proceedings of the 4th conference, 195-199. London: Geological Society.

Cotter, E. 1983: Shelf, paralic, and fluvial environments and eustatic sea-level fluctuations in the origin of the Tuscarora Formation (Lower Silurian) of central Pennsylvania. Journal of Sedimentary Petrology 53, 25-49.

Curran, H.A. 1985: The trace fossil assemblage of a Cretaceous nearshore environment: Englishtown Formation of Delaware, 
U.S.A. In: Curran, H.A. (ed.): Biogenic structures: their use in interpreting depositional environments. Society of Economic Paleontologists and Mineralogists Special Publication 35, 261-276.

Dabrio, C.J. \& Polo, M.D. 1981: Flow regime and bedforms in a ridge and runnel system, S.E. Spain. Sedimentary Geology 28 , 97-110.

Dalrymple, R.W., Zaitlin, B.A. \& Boyd, R. 1992: Estuarine facies models: conceptual basis and stratigraphic implications. Journal of Sedimentary Petrology 62, 1130-1146.

Dam, G. \& Surlyk, F. 1993: Cyclic sedimentation in a large waveand storm-dominated anoxic lake; Kap Stewart Formation (Rhaetian-Sinemurian), Jameson Land, East Greenland. In: Posamentier, H.W. et al. (eds): Sequence stratigraphy and facies associations. International Association of Sedimentologists Special Publication 18, 419-448.

Dam, G. \& Surlyk, F. 1998: Stratigraphy of the Neill Klinter Group; a Lower - lower Middle Jurassic tidal embayment succession, Jameson Land, East Greenland. Geology of Greenland Survey Bulletin 175, 80 pp.

Dam, G., Surlyk, F., Mathiesen, A. \& Christiansen, F.G. 1995: Exploration significance of lacustrine forced regressions of the Rhaetian-Sinemurian Kap Stewart Formation, Jameson Land, East Greenland. In: Steel, R.J. et al. (eds): Sequence stratigraphy on the Northwest European margin. Norwegian Petroleum Society (NPF) Special Publication 5, 511-527.

Davis, R.A. \& Fox, W.T. 1972: Coastal processes and nearshore sand bars. Journal of Sedimentary Petrology 42, 401-412.

de Raaf, J.F.M. \& Boersma, J.R. 1971: Tidal deposits and their sedimentary structures (seven examples from Western Europe). Geologie en Mijnbouw 50, 479-504.

Donovan, D.T. 1953: The Jurassic and Cretaceous stratigraphy and palaeontology of Traill $\varnothing$, East Greenland. Meddelelser om Grønland 111(4), 150 pp.

Doré, A.G. 1991: The structural foundation and evolution of Mesozoic seaways between Europe and the Arctic. Palaeogeography, Palaeoclimatology, Palaeoecology 87, 441-492.

Doré, A.G. 1992: Synoptic palaeogeography of the Northeast Atlantic Seaway: Late Permian to Cretaceous. In: Parnell, J. (ed.): Basins on the Atlantic seaboard: petroleum geology, sedimentology and basin evolution. Geological Society Special Publication (London) 62, 421-446.

Dörjes, J. \& Hertweck, G. 1975: Recent biocoenosis and ichnocoenosis in shallow-water marine environments. In: Frey, R.W. (ed.): The study of trace fossils, 459-491. New York: Springer Verlag.

Ekdale, A., Bromley, R.G. \& Pemberton, S.G. 1984: The use of trace fossils in sedimentology and stratigraphy. Society of Economic Paleontologists and Mineralogists Short Course Notes 15, 317 pp.

Engkilde, M. 1994: The Middle Jurassic Vardekløft Formation, East Greenland: depositional environments and sequence stratigraphy of shallow marine sandstones deposited in a lowgradient epeiric seaway, 207 pp. Unpublished Ph.D. thesis, University of Copenhagen, Denmark.

Engkilde, M. \& Surlyk, F. 1993: The Middle Jurassic Vardekløft Formation of East Greenland - analogue for reservoir units of the Norwegian shelf and the northern North Sea. In: Parker, J.R. (ed.): Petroleum geology of Northwest Europe: proceedings of the 4th conference, 533-542. London: Geological Society.

Eynon, G. 1981: Basin development and sedimentation in the Middle Jurassic of the northern North Sea. In: Illing, L.V. \& Hobson, G.D. (eds): Petroleum geology of the continental shelf of North-West Europe: proceedings of the 2nd conference, 196-204. London: Heyden \& Son Ltd.

Frey, R.W. 1975: The realm of ichnology, its strengths and limitations. In: Frey, R.W. (ed.): The study of trace fossils, 13-38. New York: Springer Verlag.

Fürsich, F.T. 1984: Benthic macroinvertebrate associations from the Boreal Upper Jurassic of Milne Land, central East Greenland. Bulletin Grønlands Geologiske Undersøgelse 149, 72 pp.

Gjelberg, J., Dreyer, T., Høie, A., Tjelland, T. \& Lilleng, T. 1987: Late Triassic to Mid Jurassic sandbody development on the Barents and Mid-Norwegian shelf. In: Brooks, J. \& Glennie, K.W. (eds): Petroleum geology of North West Europe, 1105-1130. London: Graham \& Trotman.

Gradstein, F.M., Agterberg, F.P., Ogg, J.G., Hardenbol, J., van Veen, P., Thierry, J. \& Huang, Z. 1994: A Mesozoic time scale. Journal of Geophysical Research 99, 24051-24074.

Hallam, A. 1988: A reevaluation of Jurassic eustasy in the light of new data and the revised Exxon curve. In: Wilgus, C.K. et al. (eds): Sea-level changes - an integrated approach. Society of Economic Paleontologists and Mineralogists Special Publication 42, 261-273.

Hallam, A. \& Sellwood, B.W. 1976: Middle Mesozoic sedimentation in relation to tectonics in the British area. Journal of Geology 84, 301-321.

Haller, J. 1971: Geology of the East Greenland Caledonides, 413 pp. London: Interscience Publishers.

Harms, J.C. 1975: Stratification produced by migrating bed forms. In: Harms, J.C. et al. (eds): Depositional environments as interpreted from primary sedimentary structures and stratification sequences. Society of Economic Paleontologists and Mineralogists Short Course 2, 45-61.

Hart, B.S. \& Plint, A.G. 1993: Origin of an erosion surface in shoreface sandstones of the Kakwa Member (Upper Cretaceous Cardium Formation, Canada): importance for reconstruction of stratal geometry and depositional history. In: Posamentier, H.W. et al. (eds): Sequence stratigraphy and facies associations. International Association of Sedimentologists Special Publication 18, 451-468.

Heinberg, C. \& Birkelund, T. 1984: Trace fossil assemblages and basin evolution of the Vardekløft Formation (Middle Jurassic, Central East Greenland). Journal of Palaeontology 58, 362-397.

Helland-Hansen, W., Ashton, M., Lømo, L. \& Steel, R. 1992: Advance and retreat of the Brent Delta: recent contributions to the depositional model. In: Morton, A.C. et al. (eds): Geology of the Brent Group. Geological Society Special Publication (London) 61, 109-127.

Howard, J.D. \& Nelson, C.H. 1982: Sedimentary structures on a delta-influenced shallow shelf, Norton Sound, Alaska. In: Nelson, C.H. \& Nio, S. (eds): The northeastern Bering shelf, new perspectives of epicontinental shelf processes and depo- 
sitional products. Geologie en Mijnbouw 61, 29-36.

Hunter, R.E., Clifton, H.E. \& Phillips, R.L. 1979: Depositional processes, sedimentary structures and predicted vertical sequences in barred nearshore systems. Southern Oregon coast. Journal of Sedimentary Petrology 49, 711-726.

Johnson, C. \& Gallagher, K. 2000: A preliminary Mesozoic and Cenozoic denudation history of the North-East Greenland onshore margin. Global and Planetary Change 24, 261-274.

Jones, C.E., Jenkyns, H.C., Coe, A.L. \& Hesselbo, S.P. 1994: Sr isotopic variations in Jurassic and Cretaceous seawaters. Geochimica et Cosmochimica Acta 58, 3061-3074.

Koch, L. 1929: The geology of East Greenland. Meddelelser om Grønland 73 2. Afd.(1), 204 pp.

Koch, L. 1950: Report on the expeditions to central East Greenland 1926-1939 conducted by Lauge Koch. Part I. Notes on some topographical and geological maps of East Greenland. Meddelelser om Grønland 143(1), 11 pp.

Koppelhus, E.B. \& Hansen, C.F. 2003: Palynostratigraphy and palaeoenvironment of the Middle Jurassic Sortehat Formation (Neill Klinter Group), Jameson Land, East Greenland. In: Ineson, J.R. \& Surlyk, F. (eds): The Jurassic of Denmark and Greenland. Geological Survey of Denmark and Greenland Bulletin 1, 777-811 (this volume).

Larsen, H.C. 1990: The East Greenland shelf. In: Grantz, A., Johnson, L. \& Sweeney, J.F. (eds): The Arctic Ocean region. The geology of North America L, 186-210. Boulder, Colorado: Geological Society of America.

Larsen, H.C. \& Marcussen, C. 1992: Sill-intrusion, flood basalt emplacement and deep crustal structure of the Scoresby Sund region, East Greenland. In: Storey, B.C., Alabaster, T. \& Pankhurst, R.J. (eds): Magmatism and the causes of continental break-up. Geological Society Special Publication (London) 68, 365-386.

Larsen, M. \& Surlyk, F. 2003: Shelf-edge delta and slope deposition in the Upper Callovian - Middle Oxfordian Olympen Formation, East Greenland. In: Ineson, J.R. \& Surlyk, F. (eds): The Jurassic of Denmark and Greenland. Geological Survey of Denmark and Greenland Bulletin 1, 931-948 (this volume).

Larsen, M., Piasecki, S. \& Surlyk, F. 2003: Stratigraphy and sedimentology of a basement-onlapping shallow marine sandstone succession, the Charcot Bugt Formation, Middle-Upper Jurassic, East Greenland. In: Ineson, J.R. \& Surlyk, F. (eds): The Jurassic of Denmark and Greenland. Geological Survey of Denmark and Greenland Bulletin 1, 893-930 (this volume).

Lund, J.J. \& Pedersen, K.R. 1985: Palynology of the marine Jurassic formations in the Vardekløft ravine, Jameson Land, East Greenland. Bulletin of the Geological Society of Denmark 33, 371-399.

Madsen, V. 1904: On Jurassic fossils from East Greenland. Meddelelser om Grønland 29(6), 157-211.

Mathiesen, A., Bidstrup, T. \& Christiansen, F.G. 2000: Denudation and uplift history of the Jameson Land basin, East Greenland - constrained from maturity and apatite fission track data. Global and Planetary Change 24, 275-301.

Mitchener, B.C., Lawrence, D.A., Partington, M.A., Bowman, M.B.J. \& Gluyas, J. 1992: Brent Group: sequence stratigraphy and regional implications. In: Morton, A.C. et al. (eds): Geology of the Brent Group. Geological Society Special Publication (London) 61, 45-80.

Mitchum, R.M. \& Van Wagoner, J.C. 1991: High-frequency sequences and their stacking patterns: sequence-stratigraphic evidence of high-frequency eustatic cycles. Sedimentary Geology 70, 131-160.

Morton, R.A. \& McGowen, J.H. 1980: Modern deposits of the Texas coast. Guidebook 20, 167 pp. Austin, Texas: Bureau of Economic Geology, University of Texas at Austin.

Nelson, C.H. 1982: Modern shallow water graded sand layers from storm surges, Bering shelf: a mimic of Bouma sequences and turbidite systems. Journal of Sedimentary Petrology 52, 537-547.

Nio, S.D. \& Yang, C.H. 1991: Diagnostic attributes of clastic tidal deposits, a review. In: Smith, D.G. et al. (eds): Clastic tidal sedimentology. Canadian Society of Petroleum Geologists Memoir 16, 3-27.

Nummedal, D. \& Swift, D.J.P. 1987: Transgressive stratigraphy at sequence-bounding unconformities: some principles derived from Holocene and Cretaceous examples. In: Nummedal, D., Pilkey, O.H. \& Howard, J.D. (eds): Sea-level fluctuation and coastal evolution. Society of Economic Paleontologists and Mineralogists Special Publication 41, 241-260.

Nummedal, D., Riley, G.W. \& Templet, P.L. 1993: High resolution sequence architecture: a chronostratigraphic model based on equilibrium profile studies. In: Posamentier, H.W. et al. (eds): Sequence stratigraphy and facies associations. International Association of Sedimentologists Special Publication 18, 55-68.

Oomkens, E. 1974: Lithofacies relations in the Late Quarternary Niger delta Complex. Sedimentology 21, 195-222.

Pemberton, S.G. \& Frey, R.W. 1985: The Glossifungites ichnofacies: modern examples from the Georgia coast, U.S.A. In: Curran, H.A. (ed.): Biogenic structures: their use in interpreting depositional environments. Society of Economic Paleontologists and Mineralogists Special Publication 35, 237-259.

Plint, A.G. 1988: Sharp-based shoreface sequences and 'offshore bars' in the Cardium Formation of Alberta: their relationship to relative changes in sea level. In: Wilgus, C.K. et al. (eds): Sea-level changes - an integrated approach. Society of Economic Paleontologists and Mineralogists Special Publication 42, 357-370

Plint, A.G. \& Nummedal, D. 2000: The falling stage systems tract: recognition and importance in sequence stratigraphic analysis. In: Hunt, D. \& Gawthorpe, R.L. (eds): Sedimentary responses to forced regressions. Geological Society Special Publication (London) 172, 1-17.

Pollard, J.E., Goldring, R. \& Buck, S.G. 1993: Ichnofabrics containing Ophiomorpha: significance in shallow water facies interpretation. Journal of the Geological Society (London) 150, 149-164.

Posamentier, H.W. \& Vail, P.R. 1988: Eustatic controls on clastic deposition II - sequence and systems tract models. In: Wilgus, C.K. et al. (eds): Sea-level changes - an integrated approach. Society of Economic Paleontologists and Mineralogists Special Publication 42, 125-154.

Posamentier, H.W., Jervey, M.T. \& Vail, P.R. 1988: Eustatic controls on clastic deposition I - conceptual framework. In: Wilgus, 
C.K. et al. (eds): Sea-level changes - an integrated approach. Society of Economic Paleontologists and Mineralogists Special Publication 42, 109-124.

Price, S.P. \& Whitham, A.G. 1997: Exhumed hydrocarbon traps in East Greenland: analogs for the Lower-Middle Jurassic play of Northwest Europe. American Association of Petroleum Geologists Bulletin 81, 196-221.

Reineck, H.E. 1972: Tidal flats. In: Rigby, J.K. \& Hamblin, W.K. (eds): Recognition of ancient sedimentary environments. Society of Economic Paleontologists and Mineralogists Special Publication 16, 146-159.

Rosenkrantz, A. 1929: Preliminary account of the geology of the Scoresby Sound district. Meddelelser om Grønland 73(2), $135-154$.

Rosenkrantz, A. 1934: The Lower Jurassic rocks of East Greenland, part 1. Meddelelser om Grønland 110(1), 122 pp.

Rosenkrantz, A. 1942: The Lower Jurassic rocks of East Greenland, part 2. The Mesozoic sediments of the Kap Hope area, southern Liverpool Land. Meddelelser om Grønland 110(2), 56 pp.

Sarjeant, W.A.S. 1972: Dinoflagellate cysts and acritarchs from the Upper Vardekløft Formation (Jurassic) of Jameson Land, East Greenland. Meddelelser om Grønland 195(4), 1-69.

Seilacher, A. 1967: Bathymetry of trace fossils. Marine Geology 5, 413-428.

Sellwood, B.W. \& Hallam, A. 1974: Bathonian volcanicity and North Sea rifting. Nature 252, 27-28.

Sha, L.P. \& de Boer, P.L. 1991: Ebb-tidal delta deposits along the west Frisian Islands (The Netherlands): processes, facies architecture and preservation. In: Smith, D.G. et al. (eds): Clastic tidal sedimentology. Canadian Society of Petroleum Geologists Memoir 16, 199-218.

Smelror, M. 1988: Bathonian to Early Oxfordian dinoflagellate cysts and acritarchs from Kong Karls Land, Svalbard. Review of Palaeobotany and Palynology 56, 275-304.

Spath, L.F. 1932: The invertebrate faunas of the BathonianCallovian deposits of Jameson Land (East Greenland). Meddelelser om Grønland 87(7), 158 pp.

Spath, L.F. 1947: Additional observations on the invertebrates (chiefly ammonites) of the Jurassic and Cretaceous of East Greenland. I. The Hectoroceras fauna of SW Jameson Land. Meddelelser om Grønland 132(3), 70 pp.

Stauber, H. 1940: Stratigraphisch-geologische Untersuchungen in der Ostgrönländischen Senkungszone des nördlichen Jamesonlandes. Meddelelser om Grønland 114(7), 34 pp.

Steel, R.J. 1993: Triassic-Jurassic megasequence stratigraphy in the northern North Sea: rift to post-rift evolution. In: Parker, J.R. (ed.): Petroleum geology of Northwest Europe: proceedings of the 4th conference, 299-315. London: Geological Society.

Stemmerik, L., Clausen, O.R., Korstgård, J., Larsen, M., Piasecki, S., Seidler, L., Surlyk, F. \& Therkelsen, J. 1997: Petroleum geological investigations in East Greenland: project 'Resources of the sedimentary basis of North and East Greenland'. Geology of Greenland Survey Bulletin 176, 29-38.

Surlyk, F. 1977a: Mesozoic faulting in East Greenland. In: Frost, R.T.C. \& Dikkers, A.J. (eds): Fault tectonics in NW Europe. Geologie en Mijnbouw 56, 311-327.
Surlyk, F. 1977b: Stratigraphy, tectonics and palaeogeography of the Jurassic sediments of the areas north of Kong Oscars Fjord, East Greenland. Bulletin Grønlands Geologiske Undersøgelse 123, 56 pp.

Surlyk, F. 1978: Jurassic basin evolution of East Greenland. Nature 274, 130-133.

Surlyk, F. 1987: Slope and deep shelf gully sandstones, Upper Jurassic, East Greenland. American Association of Petroleum Geologists Bulletin 71, 464-475.

Surlyk, F. 1990a: Timing, style and sedimentary evolution of Late Palaeozoic - Mesozoic extensional basins of East Greenland. In: Hardman, R.F.P. \& Brooks, J. (eds): Tectonic events responsible for Britain's oil and gas reserves. Geological Society Special Publication (London) 55, 107-155.

Surlyk, F. 1990b: A Jurassic sea-level curve for East Greenland. Palaeogeography, Palaeoclimatology, Palaeoecology 78, 71-85.

Surlyk, F. 1991: Sequence stratigraphy of the Jurassic - lowermost Cretaceous of East Greenland. American Association of Petroleum Geologists Bulletin 75, 1468-1488.

Surlyk, F. 2003: The Jurassic of East Greenland: a sedimentary record of thermal subsidence, onset and culmination of rifting. In: Ineson, J.R. \& Surlyk, F. (eds): The Jurassic of Denmark and Greenland. Geological Survey of Denmark and Greenland Bulletin 1, 659-722 (this volume).

Surlyk, F. \& Birkelund, T. 1972: The geology of southern Jameson Land. Rapport Grønlands Geologiske Undersøgelse 48, 61-74.

Surlyk, F. \& Clemmensen, L.B. 1983: Rift propagation and eustacy as controlling factors during Jurassic inshore and shelf sedimentation in northern East Greenland. Sedimentary Geology 34, 119-143.

Surlyk, F. \& Noe-Nygaard, N. 1991: Sand bank and dune facies architecture of a wide intracratonic seaway: Late Jurassic - Early Cretaceous Raukelv Formation, Jameson Land, East Greenland. In: Miall, A.D. \& Tyler, N. (eds): The three-dimensional facies architecture of terrigenous clastic sediments and its implication for hydrocarbon discovery and recovery. SEPM (Society for Sedimentary Geology) Concepts in Sedimentology and Palaeontology 3, 261-276.

Surlyk, F. \& Noe-Nygaard, N. 1995: High-angle clinoform beds a recurrent architectural element in Jurassic shallow marine deposits of East Greenland. Sedimentary responses to forced regressions: recognition, interpretation and reservoir potential, Geological Society, London, 7-9 September 1995. Programme with abstracts, 64-65.

Surlyk, F. \& Noe-Nygaard, N. 1998: Massive intrusive sandstones, Upper Jurassic Hareelv Formation, East Greenland: a new class of deep-water sandstones. Geoscience '98, Keele University, 14-18 April, 1998. Abstracts, 7 only.

Surlyk, F. \& Noe-Nygaard, N. 2000: Jurassic sequence stratigraphy of East Greenland. In: Hall, R.L. \& Smith, P.L. (eds): Advances in Jurassic research 2000. Proceedings of the 5th International Symposium on the Jurassic System. GeoResearch Forum 6, 357-366.

Surlyk, F. \& Noe-Nygaard, N. 2001a: Cretaceous faulting and associated coarse-grained marine gravity flow sedimentation, Traill $\varnothing$, East Greenland. In: Martinsen, O.J. \& Dreyer, T. (eds): Sedimentary environments offshore Norway - Palaeozoic to 
Recent. Norwegian Petroleum Society (NPF) Special Publication 10, 293-319.

Surlyk, F. \& Noe-Nygaard, N. 2001b: Sand remobilisation and intrusion in the Upper Jurassic Hareelv Formation of East Greenland. In: Surlyk, F. \& Håkansson, E. (eds): Oscar volume. Bulletin of the Geological Society of Denmark 48, 211-230.

Surlyk, F., Callomon, J.H., Bromley, R.G. \& Birkelund, T. 1973: Stratigraphy of the Jurassic - Lower Cretaceous sediments of Jameson Land and Scoresby Land, East Greenland. Bulletin Grønlands Geologiske Undersøgelse 105, 76 pp.

Surlyk, F., Clemmensen, L.B. \& Larsen, H.C. 1981: Post-Palaeozoic evolution of the East Greenland continental margin. In: Kerr, J.W. \& Ferguson, A.J. (eds): Geology of the North Atlantic Borderlands. Canadian Society of Petroleum Geologists Memoir 7, 611-645.

Surlyk, F., Hurst, J.M., Piasecki, S., Rolle, F., Scholle, P.A., Stemmerik, L. \& Thomsen, E. 1986: The Permian of the western margin of the Greenland Sea - a future exploration target. In: Halbouty, M.E. (ed.): Future petroleum provinces of the world. American Association of Petroleum Geologists Memoir 40, 629-659.

Surlyk, F., Noe-Nygaard, N. \& Dam, G. 1993: High and low resolution sequence stratigraphy in lithological prediction - examples from the Mesozoic around the northern North Atlantic. In: Parker, J.R. (ed.): Petroleum geology of Northwest Europe: proceedings of the 4th conference, 199-214. London: Geological Society.

Surlyk, F., Arndorff, L., Hamann, N.-E., Hamberg, L., Johannessen, P.N., Koppelhus, E.B., Nielsen, L.H., Noe-Nygaard, N., Pedersen, G.K. \& Petersen, H.I. 1995: High-resolution sequence stratigraphy of a Hettangian-Sinemurian paralic succession, Bornholm, Denmark. Sedimentology 42, 323-354.

Swift, D.J.P. \& Thorne, J.A. 1991: Continental margin sedimentation - general model. In: Swift, D.J.P. et al. (eds): Shelf sand and sandstone bodies, geometry, facies and sequence stratigraphy. International Association of Sedimentologists Special Publication 14, 3-31.

Swift, D.J.P., Phillips, S. \& Thorne, J.A. 1991: Sedimentation on continental margins, V: parasequences. In: Swift, D.J.P. et al. (eds): Shelf sand and sandstone bodies, geometry, facies and sequence stratigraphy. International Association of Sedimentologists Special Publication 14, 153-187.

Terwindt, J.H.J. 1971: Litho-facies of inshore estuarine and tidalinlet deposits. Geologie en Mijnbouw 50, 515-526.

Terwindt, J.H.J. 1981: Origin and sequences of sedimentary structures in inshore mesotidal deposits of the North Sea. In: Nio, S.D., Schüttenhelm, R.T.E. \& van Weering, T.C.E. (eds): Holocene marine sedimentation in the North Sea Basin. International Association of Sedimentologists Special Publication 5, 4-26.

Terwindt, J.H.J. 1988: Palaeo-tidal reconstructions of inshore tidal depositional environments. In: de Boer, P.L., van Gelder, A. \& Nio, S.D. (eds): Tide-influenced sedimentary environments and facies, 233-263. Dordrecht, the Netherlands: Reidel
Publishing Company for the University of Utrecht.

Therkelsen, J. \& Surlyk, F. in press: The fluviatile Bristol Elv Formation, a new Middle Jurassic lithostratigraphical unit from Traill $\varnothing$, North-East Greenland. In: Stemmerik, L. \& Stouge, S. (eds): The Jurassic of North-East Greenland. Geological Survey of Denmark and Greenland Bulletin.

Underhill, J.R. \& Partington, M.A. 1993: Jurassic thermal doming and deflation in the North Sea: implications of the sequence stratigraphic evidence. In: Parker, J.R. (ed.): Petroleum geology of Northwest Europe: proceedings of the 4th conference, 337-345. London: Geological Society.

Underhill, J.R. \& Partington, M.A. 1994: Use of genetic sequence stratigraphy in defining and determining a regional tectonic control on the 'Mid-Cimmerian Unconformity' - implications for North Sea basin development and the global sea-level chart. In: Weimer, P. \& Posamentier, H.W. (eds): Siliciclastic sequence stratigraphy: recent developments and applications. American Association of Petroleum Geologists Memoir 58 , 449-484.

Van Wagoner, J.C., Mitchum, R.M., Campion, K.M. \& Rahmanian, V.D. 1990: Siliciclastic sequence stratigraphy in well logs, cores, and outcrops: concepts for high-resolution correlation of time and facies. American Association of Petroleum Geologists, Methods in Exploration Series 7, 55 pp.

Vischer, A. 1943: Die postdevonische Tektonik von Ostgrönland zwischen $74^{\circ}$ und $75^{\circ} \mathrm{N}$. Br., Kuhn $\varnothing$, Wollaston Forland, Clavering $\varnothing$ und angrenzende Gebiete. Meddelelser om Grønland 133(1), 195 pp.

Vosgerau, H., Larsen, M., Piasecki, S. \& Therkelsen, J. in press a: A new Middle-Upper Jurassic succession of Hold with Hope, North-East Greenland. In: Stemmerik, L. \& Stouge, S. (eds): The Jurassic of North-East Greenland. Geological Survey of Denmark and Greenland Bulletin.

Vosgerau, H., Alsen, P., Carr, I.D., Therkelsen, J., Stemmerik, L. \& Surlyk, F. in press b: Jurassic syn-rift sedimentation on a seawards tilted fault block, Traill $\varnothing$, North-East Greenland. In: Stemmerik, L. \& Stouge, S. (eds): The Jurassic of North-East Greenland. Geological Survey of Denmark and Greenland Bulletin.

Whiteman, A.J., Rees, G., Naylor, D. \& Pegrum, R.M. 1975: North Sea troughs and plate tectonics. Norges Geologiske Undersøkelse 316, 137-161.

Yang, C.S. \& Nio, S.D. 1989: An ebb-tide delta depositional model - a comparison between the modern Eastern Scheldt tidal basin (southwest Netherlands) and the Lower Eocene Roda Sandstone in the southern Pyrenees (Spain). Sedimentary Geology 64, 175-196.

Ziegler, P.A. 1988: Evolution of the Arctic - North Atlantic and the western Tethys. American Association of Petroleum Geologists Memoir 43, 198 pp.

Ziegler, P.A. 1990: Geological atlas of western and central Europe, 2nd edition, 239 pp. Amsterdam: Elsevier for Shell Internationale Petroleum Maatschappij. 
